Coleção Micropolítica do Trabalho e o Cuidado em Saúde Ricardo Luiz Narciso Moebus

\title{
O Trágico na Produção do Cuidado Uma Estética da Saúde Mental
}

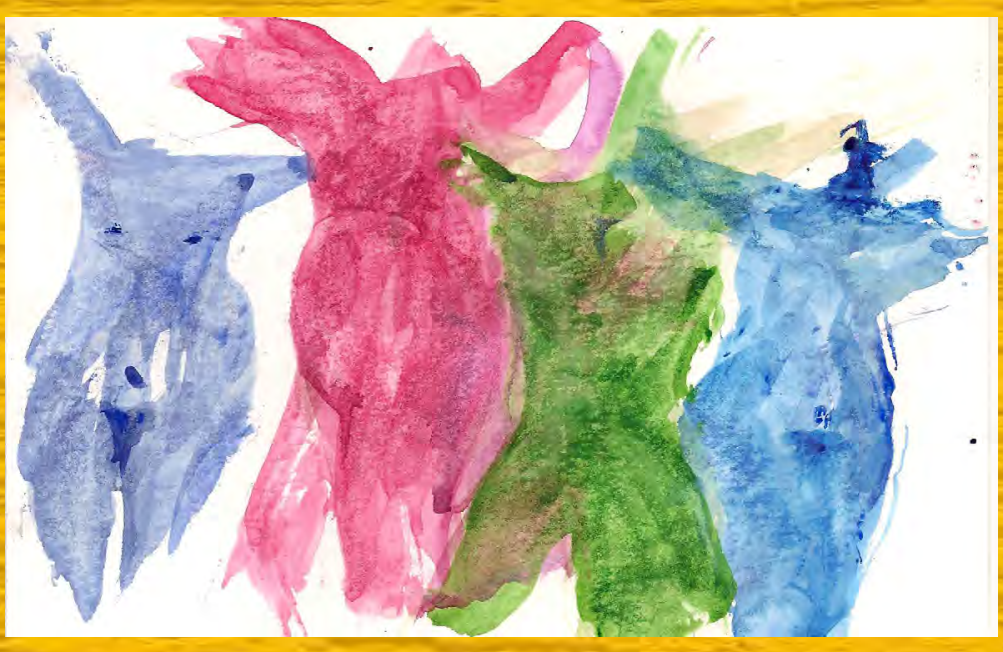

editora

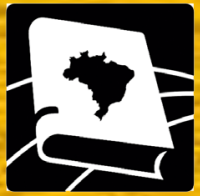

redeunida 

Coleção Micropolítica do Trabalho e o Cuidado em Saúde

Ricardo Luiz Narciso Moebus

\section{O Trágico na Produção do Cuidado Uma Estética da Saúde Mental}

1a Edição, Revisada

Porto Alegre, 2014

Rede UNIDA 
Coordenador Nacional da Rede UNIDA

Alcindo Antônio Ferla

\section{Coordenação Editorial}

Alcindo Antônio Ferla

\section{Conselho Editorial}

Alcindo Antônio Ferla

Emerson Elias Merhy

Ivana Barreto

João José Batista de Campos

João Henrique Lara do Amaral

Julio César Schweickardt

Laura Camargo Macruz Feuerwerker

Lisiane Böer Possa

Mara Lisiane dos Santos

Márcia Cardoso Torres

Marco Akerman

Maria Luiza Jaeger

Ricardo Burg Ceccim

Maria Rocineide Ferreira da Silva

Rossana Baduy

Sueli Barrios

Vanderléia Laodete Pulga

Vera Kadjaoglanian

Vera Rocha

\section{DADOS INTERNACIONAIS PARA CATALOGAÇÃO NA PUBLICAÇÃO (CIP)}

M693t Moebus, Ricardo Luiz Narciso.

O trágico na produção do cuidado : uma estética da saúde mental / Ricardo Luiz Narciso Moebus. - Porto Alegre: Rede UNIDA, 2014.

252 p.: il. - (Coleção Micropolítica do Trabalho e o Cuidado em Saúde)

Bibliografia

ISBN 9978-85-66659-29-0

1. Assistência a saúde mental 2. Atenção à saúde 3. Estética 4. Política social I. Título II. Série

NLM WM30

Catalogação na fonte: Rubens da Costa Silva Filho CRB10/1761

Todos os direitos desta edição reservados à

ASSOCIAÇÃO BRASILEIRA REDE UNIDA

Rua São Manoel, no 498 - 90620-110 - Porto Alegre - RS

Fone: (51) 3391-1252

www.redeunida.org.br 
Para minhas filhas Maria Tereza, Maria Clara e Maria Luíza Três Marias é a constelação regente em meu céu astral. 

“Gracias a La vida

Que me há dado tanto"

Violeta Parra

"Num mundo feio não pode existir liberdade" Herbert Marcuse ${ }^{1}$

${ }^{1}$ Marcuse (apud COHN; PIMENTA, 2008, p.104). 



\section{Sumário}

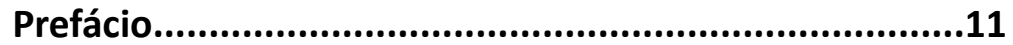

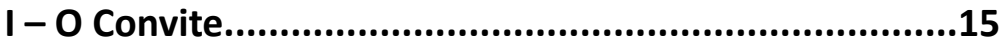

II-Governamentalidade..................................................41

III-Tragicamentalidade................................................71

IV - O Metódico...............................................................

V - Cuidado.....................................................................127

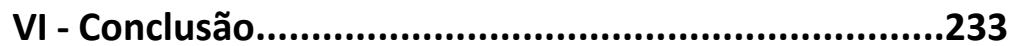

VII-Referências..............................................................241 



\section{Prefácio}

\section{É possivel uma experiência antifascista?}

Dessas que temos que exercitar quando o encontro com o outro é tão radical que nos coloca de modo estético e ético em muitas dúvidas. Em momentos que mobilizam, em muitos, repulsas efetivas, mal-estar em estar com o outro tão distinto, que temos vontade de nos afastar. Quando esse outro é visto por nós não como diferença mas como desigualdade, que inclusive, do ponto de vista ético, nos autoriza agir sobre ele, dominá-lo.

Lógico que isso varia e muito, pois há casos em que a diferença que está instalada é mero detalhe para uns, mas esses mesmos, em outras situações, podem agir de modo fascista em outros tipos de instalação de diferenças. Não há como estabelecer qual diferença instala dificuldades em tomar o outro como simétrico, como válido em si, como diferença que agrega em nós mais vida e não rejeição.

Cada um de nós, que somos em si sempre muitos nós, tem experiências disso no andar e caminhar nas nossas muitas formas de existir, nesse nosso devir-multidão.

Há, de modo concreto, encontros que não são agradáveis para uns e os são para outros. 
Vejo uma criança, dessas consideradas comuns entre nós, encontrando uma outra que para muitos é incomodativo como, por exemplo, uma criança com albinismo. E reparo que começam a conversar a se atraírem e a se movimentarem para acordos de jogos entre si, começam a brincar e a papear. Converso depois com elas separadamente e vejo que adoraram estar juntas.

Mas, eu, de fora, olhando tudo isso fico ali engalfinhado, como será que a considerada comum vai "aceitar" a outra, albina. Não me passa na cabeça pensar o contrário no momento, só depois: como que a tida como a mais portadora de diferenças - o que é já um julgamento bem limitado sobre isso de diferenças, pois toma algo de diferente para instalar qualitativamente relação na diferença e mesmo desigualdade - vai sentir a outra que para si é diferença, também.

No primeiro momento não consigo pensar simetricamente: o outro é a minha diferença, seja esse qualquer outro, tido como humano ou não, para muitos de nós. Aqui, só lembro que há alguns que não separam humanos e não humanos, pois todos são humanos no plano da vida: como indica vários pensadores, a onça é tão humana quanto qualquer um.

Volto a mim. No primeiro olhar instalo a diferença e de modo unidirecional, mesmo que as crianças não tenham feito isso.

Será que algum tipo de incomodo me desloca e me permite pensar sobre isso, no ato?

Vejo que tenho dificuldade, mas percebo que há algo que mexe ali. Cedo e consigo perceber que estou sendo unidirecional, mas que poderia mudar a vista do meu ponto de vista e sentir a simetria em mim: elas eram a diferença em mim. 
Então, o que faço com isso?

Posso perceber novos sentidos e isso pode fazer com que outros tipos de encontros, mais radicais ainda, com diferenças que são tão fortes que chegam a não ter vozes, em nós, possam pedir passagem e me fazer já operar no agir simétrico, no posicionamento ético que a existência do outro em si é válida, se implicar em acionar mais vida nas relações e não mortes, sendo que o acionador de mortes muitas vezes sou eu, esse eu-nós, e não o outro.

Encontrar alguém "louco muito louco", que pode me desorganizar no plano afetivo, dá para suportar e fazer que experienciemos um encontro não fascista?

Temos tido dificuldade, no contemporâneo com isso. A fábrica de subjetividades da modernidade para cá, que tem tomado um antropocentrismo radical perante qualquer forma de vida, tem gerado muitos de nós como sujeitos autocentrados, rejeitadores do que não é clone em nós e no outro. Temos agido na direção de explorar a vida do outro para tirarmos proveito de modo eu-centrado, temos sido forjados como "egoístas" e "senhores". Isso tem autorizado muitos a verem o outro como seu recurso utilizável, esse outro qualquer. Esse outro, Terra, Vida.

Um "louco muito louco" com facilidade coloca o fascismo em nós em ação.

Há dificuldades em operarmos simetricamente com diferenças tão radicais e para enfrentá-las praticamos fascismos nominando de outros jeitos.

Tomo que muito da ciência contemporânea tem fortalecido esse agir fascista em nós.

Precisamos ver isso, precisamos pensar isso no nosso próprio agir. 
Ricardo Moebus, nesse seu livro, resultado do seu doutorado, coloca isso no lugar mais profundo, na superfície da nossa pele.

De modo muito sagaz vai lá na Tragédia, vista por Nietzsche, e na Governamentalidade, oferecida por Foucault, e tira seiva, energia disso, nos propondo a Tragicamentalidade como forma de ver a constitutividade do viver, de sentir e encontrar a multiplicidade do fazer redes de conexões de existências.

Experencia isso no seu cotidiano, como trabalhador do campo da saúde mental, nos seus encontros com "loucos muito loucos" e nos oferece de modo generoso uma caixa de ferramentas muito instigante. Não para copiarmos, mas nos abalarmos e constituirmos em nós, experiências radicais de simetria com os muitos outros, em nós.

Por uma ética da vida, que: qualquer forma de vida não-fascista vale a pena, toma um posicionamento político radical.

O radical que precisamos, hoje, instalar no mundo da política das existências, em geral, mas, sobretudo, no campo das práticas de saúde, no mundo do cuidado.

A invenção do Ricardo é ANIMAdora.

Emerson Elias Merhy - 2014 


\section{I - O Convite}

"A vida é a arte do encontro, embora haja tantos desencontros pela vida"

Vinícius de Moraes

Quero pensar uma introdução que possa ser, acima de tudo, um bom convite.

Bom convite para um bom encontro. Ainda que faça aqui uma introdução aos temas abordados neste estudo - que é uma versão de minha tese de doutoramento em Medicina no grupo de pesquisa "Micropolítica do Trabalho e o Cuidado em Saúde", coordenado pelo Prof. Emerson Merhy na Universidade Federal do Rio de Janeiro - faço também o convite a passarmos por estes temas, possivelmente muitas vezes já visitados pelos leitores, ou até demasiadamente já fustigados por incontáveis leituras; convido para podermos fazer, por esses mesmos temas, uma nova travessia.

Peço que me acompanhem em uma incerta perspectiva destes temas. Então, mais do que os temas, quero apresentar aqui uma perspectiva sobre eles, uma perspectiva pela qual valha a pena revisitá-los, sem ser mero fastio. 
Enfastiados, é assim que imagino possíveis leitores, abarrotados de informações nesta era de nuvens informacionais, nuvens de tags ${ }^{2}$, que transitam por todos os poros e esporos lançados pela conectividade incessante e permanente com a informação massiva em avalanche.

Do fastio ao fausto, e vice-versa, o consumidor/ consumido neste mundo informacional é convidado a navegar aqui por mares tantas vezes navegados. $O$ que posso oferecer é então uma perspectiva que possa fazer valer a pena esta travessia, que, se tão longe está dos "mares nunca dantes navegados", possa, em contrapartida, ser um ponto de vista inusitado.

Ponto de vista, de onde a vista aponta para outras visibilidades, e, se não houver, se o leitor não puder encontrar aqui nada de novo para ver, que ele possa encontrar um novo ver sobre este nada de novo.

Portanto, à primeira vista, nada de novo para ver.

O que apresento ou interrogo aqui, o que percorro, ou sobre o que me debruço, são as práticas de saúde, o trabalho em saúde, e, em particular, o trabalho em saúde mental, e, mais especificamente, o trabalho em saúde mental no interior dos modelos assistenciais produzidos pela reforma psiquiátrica brasileira; enfocando, sobretudo, o trabalho que acontece nas redes de serviços públicos de saúde mental, a partir da invenção dos Centros de Atenção Psicossocial - CAPS $^{3}$, de onde venho trazendo minha

\footnotetext{
${ }^{2}$ Uma tag, ou em português etiqueta, é uma palavra-chave (relevante) ou termo associado com uma informação (ex: uma imagem, um artigo, um vídeo) que o descreve e permite uma classificação da informação baseada em palavras-chave. É um recurso encontrado em muitos sites de conteúdo colaborativo recentes e por essa razão, "tagging" associase com a onda Web 2.0. Extraído de http://pt.wikipedia.org/wiki/ Tag_\%28metadata\%29, em 15/02/2011.

3 Um CAPS é um serviço de saúde aberto e comunitário do Sistema Único de Saúde (SUS), lugar de referência e tratamento para pessoas com transtornos mentais graves. Ministério da Saúde, 2004b.
} 
experiência pessoal de operário da produção do cuidado em saúde mental desde $1997^{4}$.

Nada de novo, portanto, pois muito já se escreveu sobre este tipo de trabalho, seus processos de produção, suas particularidades; em especial, suas diferenças e avanços em relação aos modos tradicionais de se produzir saúde, suas vantagens em relação aos modos manicomiais de funcionamento dos ultrapassados ambulatórios de saúde mental e hospitais psiquiátricos.

Vem-se escrevendo sobre o processo de trabalho e a produção da saúde nos CAPS, pelo menos desde a publicação, em 1989, do texto de Sílvio Yasui: "CAPS: Aprendendo a Perguntar" ${ }^{5}$, portanto, há vinte e cinco anos em 2014.

Ainda que, lidando com algumas categorias, na abordagem deste processo de trabalho, que não costumam ser consideradas; ao me apoiar em concepções como a de trabalho vivo em ato, que traz para a cena o modo do trabalho em saúde se realizar sempre centrado no encontro, no acontecimento que envolve o produtor e o consumidor, acontecendo em ato; e as tecnologias leves no agir em saúde, que ressalta a predominância das tecnologias de relação, sobre as tecnologias duras (equipamentos, máquinas, normas) e leve-duras (saberes estruturados); também aqui nada de novo apresento.

Nada de novo, pois tais categorias já foram apresentadas, explicitadas e debatidas em várias ocasiões, sobretudo por Emerson Merhy, como quando apresenta suas análises sobre o tema da tecnologia em saúde:

\footnotetext{
${ }^{4}$ Ano em que comecei a trabalhar no Centro de Referência em Saúde Mental - CERSAM Leste, um dos primeiros CAPS da Prefeitura de Belo Horizonte/MG.

${ }^{5}$ YASUI, 1989. p. 47
} 
(...) ao se tomar como eixo norteador o trabalho vivo em ato, que é essencialmente um tipo de força que opera permanentemente em processo e em relações. ${ }^{6}$

Ou quando apresenta a composição das valises tecnológicas envolvidas na produção do cuidado, englobando as tecnologias duras, as leve-duras e a proeminência das tecnologias leves:

Por isso, esses processos são regidos por tecnologias leves que permitem produzir relações, expressando como seus produtos, por exemplo, a construção ou não de acolhimentos, vínculos e responsabilizações, jogos transferenciais, entre outros. ${ }^{7}$

E mesmo ao trabalhar com a delicada noção de produção do cuidado, que ultrapassa a dimensão estritamente terapêutica, ou melhor, estritamente clínica, alargando o horizonte do agir em saúde, sem necessariamente remetê-lo à ampliação da clínica; ainda assim, não apresento nada de novo, uma vez que, este tema da produção do cuidado, como sendo a alma do agir em saúde, vem sendo insistentemente afirmado por Emerson Merhy ${ }^{8}$.

O que tento construir então, neste nada de novo para ver é, à segunda vista, um novo ver sobre o nada de novo.

E, o que trago como possibilidade de novas visibilidades, é o trágico. Mas um trágico específico, a partir da concepção de uma existência trágica, ou, uma visão de mundo a partir de uma filosofia do trágico, que encontra sua expressão mais contundente em Nietzsche; o que desenvolvo melhor mais adiante.

\footnotetext{
$\overline{{ }^{6} \text { Merhy, 2002. p.62. }}$

${ }^{7}$ Ibidem, p.98.

${ }^{8}$ Ibidem, p. 161.
} 
O trágico como postura ético-estética diante da vida, como proposto por Nietzsche desde sua primeira publicação, "O Nascimento da Tragédia ou Helenismo e Pessimismo" , e reiteradamente, ao longo de sua obra.

Trágico como modo de abraçar a vida integralmente, em sua multiplicidade, em sua diversidade, em suas inumeráveis ofertas de bons encontros, mas também de maus encontros, de alegrias, mas também de tristezas, de apogeus e de quedas, com seus começos, muitas vezes belos, mas também com seus finais, muitas vezes difíceis. Assumindo suas dores, e todo o lado sombrio que possa haver, como parte que não pode ser amputada da aventura de existir, sem que isto a deixe mutilada e menor.

O trágico que utilizo aqui, como desenvolvido por Nietzsche, é abraçar a vida humana como portadora destas duas dimensões, que podem ser simbolizadas pelo apolíneo e o dionisíaco.

O apolíneo como a vida capaz de razão, de retidão, de cálculo, de repetição, de previsão, identificação, de domínio de si, clareza, discernimento, coerência. E o dionisíaco como a vida capaz de desrazão, paixão, contradição, dissolução, criação, distorção, imprevisibilidade, descontrole, turbidez, sentimento, afetação.

Uma perspectiva trágica representa então, uma aposta no reencontro destas duas dimensões, em oposição à vigência de uma perspectiva, hegemônica, que Nietzsche denominou socratismo reinante.

Neste socratismo haveria, por sua vez, a exigência da exclusividade da dimensão apolínea, com a subtração, a recusa, a negação, o banimento da perspectiva dionisíaca, como aposta civilizatória ocidental.

\footnotetext{
${ }^{9}$ Nietzsche, 2005a.
} 
O trágico fala, portanto, de uma aceitação de todas as dimensões da vida, mas, de forma alguma, de uma aceitação passiva, de resignação bem comportada. Não, o trágico ofertado por Nietzsche busca uma atitude ativa, determinada, para aproximar a vida de tudo o que ela pode; requerendo a superação de toda posição de remorso, ressentimento, culpa, desânimo. Posições estas que adoecem, diminuem, enfraquecem, empobrecem a vida.

É a posição trágica que não admite recuar diante dos maiores desafios, das maiores diferenças que esta vida nos impõe.

Fazendo retornar este conceito, que nasceu justamente na experiência prática da produção do cuidado, do então enfermeiro Nietzsche em tempos de guerra; trazendo-o de volta para este universo de aplicação, é que posso, como um desdobramento que muito interessa aqui, servir-me do trágico como analisador, como criador de visibilidades no mundo da produção da saúde.

Compartilho aqui o profundo deslocamento que este conceito pode operar sobre o olhar a vida, de forma geral; e do impacto que ele teve sobre mim, ao me permitir ampliar minha visibilidade sobre a produção da saúde, sobre o agir em saúde, sua produção como clínica, e sua produção como além da clínica.

Conceito capaz de efeitos ópticos e ex-ópticos, causando mudanças nos jogos de luzes e sombras, com os quais pintamos a realidade vivida; causando efeitos de difração, refração, reflexão ${ }^{10}$ sobre golpes de luzes, ou efeitos talvez de deslocamento, alongamento, descolamento de retinas $^{11}$, ocultos efeitos corretivos ou causadores de novas

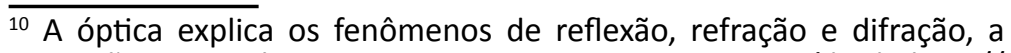
interação entre a luz e o meio, entre outras coisas. Extraído de http:// pt.wikipedia.org/wiki/\%C3\%93ptica, em 16/02/11.

${ }^{11}$ Descolamento de retina é uma enfermidade do olho caracterizada 
miopias, reguladores de novos estrabismos, lapidadores de velhos cristalinos opacos, através dos quais acreditamos tocar a superfície do mundo.

O conceito de vida trágica, em sua plenitude forjada por Nietzsche, pode ser para alguns, operários do ressentimento e do remorso que corroem a vontade de potência da vida, o derradeiro transplante de córneas. E como dói, a invasão de raios luminosos violentando antigas escuridões adormecidas.

Não menor era a pretensão de Nietzsche do que, a partir da vida trágica, dar a luz a uma nova inteireza da vida, que pudesse fazer cessar aquela que resta apartada de si mesma.

Mas um cuidado especial se faz necessário nessa metáfora, pois uma crítica severa a vida trágica traz aos iluminismos, aos esclarecimentos, ao aufklärung ${ }^{12}$, que Nietzsche debita aos socratismos reinantes. Antes, o dar a luz aqui é mesmo um parto, que coloca em cena, disponibiliza, toda luminosidade e toda a escuridão, todo o dia e toda a noite da existência, ao mesmo tempo.

Nesse sentido, a cegueira combatida nestes termos, é antes, a cegueira branca, como nos avisa Saramago ${ }^{13}$, uma cegueira mais pelo excesso de luz que pela falta, cegueira dos mergulhados no clarão, quando "(...) a terra, inteiramente iluminada, resplandeça sob o signo de triunfal desventura"14.

pela separação das camadas foto-sensível e de suporte e nutrição da retina. Extraído de http://pt.wikipedia.org/wiki/\%C3\%93ptica, em 16/02/11.

12 Iluminismo, esclarecimento, ilustração(deriva do latim iluminare, em alemão Aufklärung. "O iluminismo é a saída do homem do estado de minoridade que ele deve imputar a si mesmo. Minoridade é a incapacidade de valer-se de seu próprio intelecto sem a guia de outro." Emanuel Kant (apud REALE, 2007, p. 665).

${ }^{13}$ Saramago, 1999.

${ }^{14}$ Max Horkheimer e Theodor W. Adorno (apud Reale, 2007, p. 665). 
Vida trágica me parece, enfim, um conceito daqueles capazes de gerar um reordenamento, ou um redirecionamento do olhar, ainda que sobre um já visto, um nada de novo; e minha relação com esta produção de Nietzsche foi, em mim, portadora de uma potencialização, daquelas a que se refere Ariano Suassuna, quando diz:

Mas eu digo sempre aos estudantes que é melhor estudar um só livro, qualquer que seja ele, com 'raça', alegria e entusiasmo, do que estudar todos os livros do mundo friamente. Porque em tais casos, um livro, examinado e reexaminado em todas as suas implicações, aplaudido aqui e ferozmente negado ali, pode ser, para o jovem que o leia, o que foi, para mim, o 'Assim Falou Zaratustra', de Nietzsche, na adolescência: a descoberta da ardente e duradoura alegria do conhecimento. ${ }^{15}$

Um livro capaz de despertar em mim tamanho entusiasmo foi exatamente "O Nascimento da Tragédia"16 de Nietzsche, a partir do qual procurei desvendar esta concepção trágica da vida, este decidido Sim a vida; essa busca por uma "Grande Saúde", ou "mil saúdes e ocultas ilhas da vida"17, busca por uma inteireza, por uma aproximação da vida com o que ela pode, por esse reatar os laços que a compõem, por esse compromisso contra as "doutrinas do cansaço e da renúncia" ${ }^{18}$, contra a amputação de parte considerável da vida, parte esta denominada, nesta concepção, de dionisíaca.

Este trágico constitui o próprio movimento e reconhecimento da reintegração entre as dimensões apolíneas e dionisíacas; como ambivalência, como polivalência constitutiva da vida.

\footnotetext{
${ }^{15}$ Suassuna, 2007, p. 13.

${ }^{16}$ Nietzsche, 2005a.

${ }^{17}$ Nietzsche, 2007.

${ }^{18}$ Ibidem. p. 71.
} 
Trágico este que se constitui como uma estética, mas estética aqui, bem entendida, não como uma especialidade filosófica de apreciação do belo, mas como compromisso com a produção, a criação de si mesmo, da própria vida, como obra máxima de cada vivente.

É assim, que se pode falar em uma estética do trágico, como um compromisso com a própria vida, compromisso em reatá-la com o que ela pode, com sua potência que advém da integralidade da existência.

Sendo assim, ao aplicarmos este conceito de trágico, esta concepção de estética do trágico, ao mundo das práticas de saúde, nos encontramos com bem mais do que a racionalidade e intencionalidade clínica, nos encontramos com a produção do cuidado, enquanto produção de vida. Daí então, podemos falar de uma estética do trágico na produção do cuidado.

Caberá, a partir desta estética do trágico, revisitar as várias clínicas que compõem a produção da saúde no âmbito dos serviços de saúde mental, escopo deste estudo. Para tanto, agrupando-as, ou melhor, resumindo-as, em três blocos, ainda que sabidamente heterogêneos: as clínicas psiquiátrica, psicanalítica e psicossocial; lançando sobre as mesmas este olhar desde uma posição trágica perante a vida.

A opção por uma abordagem que considera estas três clínicas se justifica a partir do lugar de onde tento construir este olhar.

Lugar de um psiquiatra, trabalhador dos serviços de saúde mental, na segunda metade dos anos noventa e primeiras décadas do século XXI, em Minas Gerais, com as peculiaridades que isto apresenta.

Primeiramente, com uma prática necessariamente 
marcada e tributária da tradição do saber psiquiátrico; segundamente, vivendo nesta fase de emergência, implantação mais decidida, em Minas Gerais, das modelagens assistenciais da reforma psiquiátrica, com sua clínica psicossocial; terceiramente, com a influência marcante que a psicanálise imprimiu à reforma psiquiátrica especificamente em Minas Gerais.

Em relação à peculiaridade deste último ponto, vale lembrar alguns autores que reafirmam esta importância crucial da psicanálise para se entender a saúde que se fabrica no dia a dia dos serviços de saúde mental em Minas Gerais.

Nesta direção, Penido, a partir de sua pesquisa realizada em vários Centros de Referência em Saúde Mental - CERSAMs, da cidade de Belo Horizonte, entre agosto de 1998 e fevereiro de 2001, afirma que:

Dos entrevistados, todos os psiquiatras, psicólogos e um de cada dois entrevistados de categorias não-psi baseiam sua prática na Psicanálise. ${ }^{19}$

É também desta pesquisa, que Penido chega à conclusão que:

A Psicanálise lacaniana é identificada como a principal referência teórica a orientar a prática clínica dos profissionais das equipes dos CERSAMs. ${ }^{20}$

Penido ressalta também que:

O próprio Fórum Mineiro de Saúde Mental, instância representante da ideologia antimanicomial em Minas, sustenta a 'bandeira da Psicanálise', ao contrário do

\footnotetext{
${ }^{19}$ Penido, 2005. p. 97.
}

${ }^{20}$ Ibidem. p. 97. 
restante do Movimento Antimanicomial no país, conforme o ex-coordenador de saúde mental e representante do próprio Fórum. ${ }^{21}$

E ainda com Penido temos que:

Entretanto, a Psiquiatria nunca deixou de ser um discurso ou uma prática central na saúde mental, mas tão-somente passa a dividir com a Psicanálise a referência hegemônica para a clínica. ${ }^{22}$

Confirmando esta tendência da Psicanálise, insiste Penido que:

Na prática, isso nem sempre significa variedade de possibilidades no que toca ao tratamento, que se baseia, na maior parte das vezes, na escuta orientada pela Psicanálise e no uso dos psicofármacos. ${ }^{23}$

E ainda com esta mesma autora, temos que:

Mais do que opção, parece haver uma espécie de domínio consentido em relação à Psicanálise, para o qual a supervisão colabora. ${ }^{24}$

$E$, ainda como última menção a esta pesquisa de Penido, realizada nos CAPS, que em Belo Horizonte são denominados CERSAMs, temos que:

Em síntese, a supervisão, importante mecanismo de controle, enfatiza a dominância da clínica no trabalho dos CERSAMs, sobretudo da clínica psicanalítica (Freud e Lacan) e psiquiátrica (Psicopatologia e Nosologia Psiquiátrica). ${ }^{25}$

${ }^{21}$ Penido, 2005, p. 98.

${ }^{22}$ Ibidem. p. 99.

${ }^{23}$ Ibidem. p. 102.

${ }^{24} \mathrm{Ibidem}$. p. 103.

${ }^{25}$ Ibidem, p. 104. 
Encontramos também em Lobosque esta importância da Psicanálise na saúde mental em Minas, referindo-se igualmente às experiências clínicas em CERSAM:

Assim, por exemplo, na medida em que a psicanálise possui, indubitavelmente, um corpo teórico muito mais inventivo e rigoroso do que aqueles das demais disciplinas, desmontáveis com grande facilidade, em certo momento parecia que deveríamos recorrer ao seu discurso para 'fundamentar teoricamente' nossas intervenções. ${ }^{26}$

Ou ainda, quando afirma que:

A questão da presença, ou das formas de presença, da psicanálise nas práticas de Saúde Mental não é nova para mim, nem para os meios nos quais minha atividade se exerce; desempenha, aliás, um papel significativo em todo o percurso mineiro da luta antimanicomial. ${ }^{27}$

Também em Barreto encontramos esta confirmação da relevância da psicanálise na saúde mental, referindo-se à peculiaridade deste vínculo em Minas Gerais:

Devido à confluência de vários fatores, a história recente de nossos serviços púbicos de saúde mental está marcada por forte influência da psicanálise de orientação lacaniana, na sustentação do trabalho clínico com - por exemplo - psicóticos, toxicômanos e crianças, além de neuróticos. ${ }^{28}$

Por fim, Garcia, também se referindo à viabilidade de uma abordagem clínica no CERSAM, e reforçando a prerrogativa da psicanálise, afirma que:

\footnotetext{
${ }^{26}$ Lobosque, 2003. p. 34-35.

${ }^{27}$ Ibidem. p. 43.

${ }^{28}$ Barreto, 1999. p. 159.
} 
Antes de irmos adiante, vamos anotar que: a clínica é do sujeito, pois é ele político; qualquer preferência por outra entidade pesa na prática do atendimento. ${ }^{29}$

Portanto, caberá mais adiante realizar esta revisita às clínicas psiquiátrica, psicanalítica e psicossocial; lançando sobre elas esta perspectiva que trago da vida trágica.

Eis aqui uma perspectiva imprevista, que retoma sobre aqueles velhos mares navegados, novos ventos, novas ondas em novas dobras.

Mas será que, este novo ver, poderá produzir até mesmo uma superação do "não há nada de novo"?

Podemos pensar que sim, considerandoa possibilidade de que uma nova visibilidade possa ser constitutiva de um novo para se ver, nesta dança, pas-de-deux, entre olhar, visibilidade enunciados que se constituem reciprocamente, como demonstra magistralmente Michel Foucault em seu texto "O Nascimento da Clínica", já de início apresentado como um livro que trata do olhar, procurando:

(...) questionar a distribuição originária do visível e do invisível, na medida em que está ligada à separação entre o que se enuncia e o que é silenciado (...). ${ }^{30}$

E ainda:

(...) mas que a relação entre o visível e o invisível, necessária a todo saber concreto, mudou de estrutura e fez aparecer sob o olhar e na linguagem o que se encontrava aquém e além de seu domínio. Entre as palavras e as coisas se estabeleceu uma nova aliança fazendo ver e dizer (...). ${ }^{31}$

${ }^{29}$ Garcia, 2002. p. 133.

${ }^{30}$ Foucault, 2003. p. IX-X.

${ }^{31}$ Ibidem, p. X. 
Neste sentido, é que tentarei demonstrar, mais adiante, como vai surgindo deste jogo de novas visibilidades - possíveis a partir do trágico, da estética do trágico, lançada sobre as práticas clínicas - a novidade da tragicamentalidade.

Conceito irmão siamês da governamentalidade, como proposta por Michel Foucault, de forma mais evidente, a partir de seu curso no Collège de France, do ano de 1978, "Segurança, Território, População"32.

Desta forma, como quadro geral deste estudo, o convite começa por uma visita à formulação e à relevância central deste conceito Governamentalidade em Foucault, tomando por local privilegiado para reencontrá-lo, as aulas e resumos disponíveis, em português, do ensino de Foucault no Collège de France, de 1970 até sua morte em 1984.

Em seguida, já com a governamentalidade estabelecida, convido a percorrermos os caminhos que levaram à formulação do trágico, da estética do trágico, com seu apogeu em Nietzsche. E ainda neste capítulo, procedendo à aplicação do trágico à governamentalidade, podermos trazer a tona, a idéia de tragicamentalidade.

A partir daí, tomando-os por conceitosferramentas (vide logo abaixo), a governamentalidade e a tragicamentalidade, vamos revisitar as três clínicas que compõem as práticas de saúde nos serviços de saúde mental, quais sejam: as clínicas psiquiátrica, psicanalítica e psicossocial.

Desde as práticas clínicas então, é que arriscaremos este salto para além das clínicas, em direção à produção do cuidado. Saltando os altos muros da clínica, entraremos nas praias do cuidado, e é aí, que poderemos encruzilhar estes dois pares, que se desdobram e redobram, governamentalidade/tragicamentalidade e clínica/cuidado.

${ }^{32}$ Foucault, 2008a. 
Mas antes deste trajeto proposto, tomo a liberdade de esclarecer ainda alguns pontos que me parecem importantes.

O primeiro é em relação a esta aposta de interação, conexão entre prática e teoria que se chama de conceitoferramenta, e que se refere ao proposto por Gilles Deleuze em diálogo com Foucault, da seguinte maneira:

É isso. Uma teoria é exatamente como uma caixa de ferramentas. Nada a ver com o significante... É preciso que isso sirva, é preciso que isso funcione. E não para si mesmo. Se não há pessoas para dela se servirem, a começar pelo próprio teórico que cessa então de ser teórico, é porque ela não vale nada, ou porque o momento ainda não chegou. Não se retorna a uma teoria, fazem-se outras, têm-se outras a fazer. É curioso que seja um autor que passa por um puro intelectual, Proust, que o disse tão claramente: tratem meu livro como um par de óculos voltados para fora; pois bem, se eles não lhes caem bem, pequem outros, encontrem vocês mesmos seu aparelho que, forçosamente, é um aparelho de combate. ${ }^{33}$

É nesta direção que proponho aqui a retomada do conceito-ferramenta governamentalidade, mas que nunca é uma retomada, é uma nova maneira de fazê-lo funcionar, e, para tanto, ambiciono articulá-lo ao conceito-ferramenta tragicamentalidade, de forma que, juntos, possam compor uma alavanca articulada, uma máquina que nos impulsione a uma nova visibilidade, ou, "um par de óculos voltados para fora", que me parecem que servem e funcionam quando aplicados ao mundo do cuidado.

Neste sentido, é que me atrevo a falar em tragicamentalidade, como resultante de uma operação

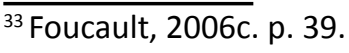


de acoplamento, ou talvez, escarificação do conceito de governamentalidade, como dobra e desdobramento desta, uma vez que:

Todo conceito tem um contorno irregular, definido pela cifra de seus componentes. É por isso que, de Platão a Bergson, encontramos a idéia de que o conceito é questão de articulação, corte e superposição. ${ }^{34}$

O segundo ponto a que me remeto antes de nos lançarmos na trajetória proposta acima, diz respeito ao efeito, produzido em mim, antes mesmo de aplicá-lo ao mundo do cuidado, pelo conceito de trágico, de vida trágica em Nietzsche, efeito de ressignificação da obra "História da Loucura", de Michel Foucault.

Insisto em me deter neste ponto, porque esta obra, e sua ressignificação a partir do trágico, encontram uma intensa relevância na trajetória de produção de clínica e cuidado que integram este estudo.

Primeiramente porque representa, em si mesma, uma verdadeira experiência limite aos saberes e fazeres da saúde mental, um xeque-mate estabelecido a partir deste fabuloso texto, praticamente inaugural na obra de Foucault.

Em segundo lugar, porque me parece que, justamente neste mesmo texto, podemos encontrar preciosas pistas para a construção de possíveis caminhos, rotas ou linhas de fuga deste xeque-mate.

Relembro que travei contato com esta obra de Foucault em 1995, em meu primeiro ano de residência médica em Psiquiatria, no Instituto Raul Soares da Fundação Hospitalar do Estado de Minas Gerais; sendo a mesma apresentada aos residentes pela, então professora de Psiquiatria Social, Ana Marta Lobosque, reconhecida militante da Luta ${ }^{34}$ Deleuze; Guattari, 2009, p. 27. 
Antimanicomial em Minas Gerais.

Para vários que, como eu, entravam a galope nesta residência, depois de vários anos de uma vocação para a saúde mental amordaçada, abafada e desprezada em um curso de medicina da Universidade Federal de Minas Gerais, que, ao menos naquela época, não priorizava definitivamente esta área, o tropeço com esta obra de Foucault era uma verdadeira flechada em nosso cavalo vocacional, que se não o fazia deitar, ao menos detinha seus arroubos.

Não que fosse este o objetivo do curso, pois certamente não era, mas acabava sendo um de seus efeitos, pois recém diplomados como médicos, ávidos para construir uma identidade, um território identitário de especialistas em psiquiatria, nos deparávamos com esta fantástica desconstrução do saber psiquiátrico, demolição de suas pretensões epistemológicas, e por decorrência, desterritorialização dos profissionais da medicina mental, entre eles os residentes.

Eu pessoalmente já cultivava interesse por este autor desde 1989 quando então li seu volume I da "História da Sexualidade - A vontade de saber", e já havia ficado muito entusiasmado não só pelo conteúdo surpreendente, mas pela forma como Foucault se dava uma invejável liberdade de pensar e expressar o surpreendente, o insuspeitado, o imprevisto. Mas então seu efeito sobre mim foi muito sutil se comparado ao impacto profundo em minha perspectiva de vida profissional causado pela "História da Loucura".

Como levar adiante minha vontade verdadeira de agir em saúde mental, de ser psiquiatra, mesmo depois daquelas palavras, revelações sobre as origens obscuras, sobre a função social da medicina mental? Como seguir construindo uma identidade profissional a partir daí? E, 
ainda mais difícil, como compatibilizar minha prática como profissional psiquiatra, mantendo-a viva, e mantendo, ao mesmo tempo, uma identificação pessoal com as causas emancipatórias, mudancistas, ou autonomistas?

Parto então do próprio Foucault para recolher algumas pistas, anunciadoras de possibilidades desta compatibilidade entre agir em saúde mental e manter um projeto, uma vontade pessoal de trabalhar pela valorização da vida, pelo respeito à dignidade de todos e de cada um, pela produção de encontros que possam ser potencializadores da vontade e da capacidade de viver mais plenamente, para que cada vida mereça ser vivida, e para que estar ainda vivo possa ser sempre um privilégio e jamais uma condenação, uma expiação.

Quero então retornar a esta que é a tese de doutoramento de Michel Foucault, como nos conta Georges Canguilhem:

Mas se há em meu trabalho universitário um momento com que me sinta feliz, ainda hoje, e de que possa me envaidecer comigo mesmo foi o de ter sido relator da tese de doutorado de Michel Foucault. ${ }^{35}$

Trata-se da "História da Loucura", defendida como tese em 20 de maio de 1961, com o título original: "Loucura e desrazão, história da loucura na idade clássica", publicada no mesmo ano, e que a partir da edição Gallimard de 1972, passou a chamar-se simplesmente, "História da Loucura na Idade Clássica"36, tradução publicada no Brasil desde 1978.

É deste livro de 1961, considerado inaugural da trajetória intelectual de Michel Foucault, ainda que houvesse publicado o pequeno "Doença Mental e

\footnotetext{
${ }^{35}$ Canguilhem, G. Abertura, in: Roudinesco, E., 1994. p. 33

${ }^{36}$ Roudinesco, 1994. p. 8.
} 
Psicologia" em 1954"37; partindo deste livro que Henri Ey, talvez o maior dos psiquiatras franceses do pós-guerra, nomeou como "psiquiatricida" ${ }^{38}$, é que procuro recolher dele especificamente algo que reverberou em mim, mas que não era evidente em si mesmo, pelo contrário, mantinhase enigmático, até poder ser ressignificado pela leitura de Nietzsche: a experiência trágica da loucura.

Foucault vai construindo desde o início deste seu texto uma passagem para uma nova sensibilidade social perante a loucura, que vai se esboçando a partir do século $\mathrm{XVI}$, e se consolidando de forma cada vez mais pronunciada nos séculos seguintes, desde a "idade clássica".

Nesta nova sensibilidade, cuja gestação e nascimento Foucault procura resgatar, acontece uma ruptura com perspectivas vigentes até o século $\mathrm{XV}$, criando um novo lugar para a loucura, no qual:

(...) esta nova realeza pouca coisa em comum tem com o reino obscuro de que falávamos ainda há pouco e que a ligava aos grandes poderes trágicos do mundo. ${ }^{39}$

Foucault apresenta uma divisão entre duas formas de experiência da loucura: por um lado, as figuras da visão cósmica, compondo o elemento trágico, e por outro lado, os movimentos da reflexão moral, compondo o elemento crítico. De um lado a loucura com sua força primitiva de revelação, e por outro lado, mera odisséia exemplar e didática dos defeitos humanos ${ }^{40}$.

Foucault insiste nesta distinção de uma possibilidade trágica para a loucura quando afirma:

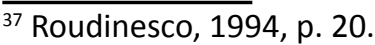

38 Ibidem. p. 11.

${ }^{39}$ Foucault, 1987. p. 23.

${ }^{40}$ Ibidem, p. 27.
} 
Em suma, a consciência crítica da loucura viuse cada vez mais posta sob uma luz mais forte, enquanto penetravam progressivamente na penumbra suas figuras trágicas. Em breve estas serão inteiramente afastadas. Será difícil encontrar vestígios delas durante muito tempo; apenas algumas páginas de Sade e a obra de Goya são testemunhas de que esse desaparecimento não significa uma derrota total: obscuramente, essa experiência trágica subsiste nas noites do pensamento e dos sonhos, e aquilo que se teve no século XVI foi não uma destruição radical mas apenas uma ocultação. A experiência trágica e cósmica da loucura viu-se mascarada pelos privilégios exclusivos de uma consciência crítica. ${ }^{41}$

E ainda sobre essa consciência trágica que se perde progressivamente a partir do século XVI, insiste Foucault:

É ela, enfim, essa consciência, que veio a exprimir-se na obra de Artaud, nesta obra que deveria propor, ao pensamento do século $X X$, se ele prestasse atenção, a mais urgente das questões, e a menos suscetível de deixar o questionador escapar à vertigem, nesta obra que não deixou de proclamar que nossa cultura havia perdido seu berço trágico desde o dia em que expulsou para fora de si a grande loucura solar do mundo, os dilaceramentos em que se realiza incessantemente a 'vida e morte de Satã, o Fogo'. ${ }^{42}$

Temos aqui, portanto, me parece claro agora diante da leitura de Nietzsche, uma referência à estética do trágico, à vida trágica, ao conceito de tragicidade como formulado em Nietzsche:

(...) a experiência da loucura que se estende do século XVI até hoje deve sua figura

${ }^{41}$ Foucalt, 1987, p. 28-29.

${ }^{42}$ Ibidem, p. 29. 
particular, e a origem de seu sentido, a essa ausência, a essa noite e a tudo que a ocupa. $A$ bela retidão que conduz o pensamento racional à análise da loucura como doença mental deve ser reinterpretada numa dimensão vertical; e neste caso verifica-se que sob cada uma de suas formas ela oculta de uma maneira mais completa e também mais perigosa essa experiência trágica que tal retidão não conseguiu reduzir. No ponto extremo da opressão, essa explosão, a que assistimos desde Nietzsche, era necessária. ${ }^{43}$

E Foucault continua desenvolvendo esta idéia, afirmando que no limiar da era clássica todas as imagens trágicas da loucura até então evocadas se dissiparam na sombra ${ }^{44}$; e que a loucura não é mais considerada em sua realidade trágica, no dilaceramento que a abre para outro mundo $^{45}$, já estando despida de suas ameaças trágicas ${ }^{46}$, exceto em obras, como já foi dito, como as de Goya e Sade que ofereceram a possibilidade de reencontrar a experiência trágica para além das promessas da dialética ${ }^{47}$.

Mas o que seria exatamente essa experiência trágica perdida? A que espécie de tragédia estava Foucault se referindo afinal? Isto não me parecia nada claro nesta sua obra, que passava, logo após este início introdutório, a se ocupar dos temas do grande internamento que arrebanhou a loucura, entre muitas outras figuras sociais, em um movimento fortemente excludente; e da construção do lugar da loucura em um mundo correcional; e das épocas do furor classificatório, do tratamento moral, do alienismo, do nascimento do asilo, etc.

\footnotetext{
$\overline{43}$ Foucault, 1987, p. 29.

${ }^{44}$ Ibidem. p. 29.

45 Ibidem. p. 40.

${ }^{46}$ Ibidem. p. 44.

${ }^{47}$ Ibidem. p. 527.
} 
Foi então, em um só depois, que a leitura de Nietzsche pode operar em mim uma causa retroagindo sobre esta obra de Foucault, sobre esta necessidade de esclarecer este ponto que era em si tão obscuro, e por isto mesmo promissor: uma sensibilidade trágica perdida, dando lugar a uma coerência que nos atravessa.

Coerência que:

(...) não é nem a de um direito nem a de uma ciência, mas sim a coerência mais secreta de uma percep̧̧ão. ${ }^{48}$

Posso entender então que é possível buscar nesta possibilidade trágica outra forma de percepção, que possa, por sua vez, exceder esta consciência que Foucault explicita como sendo crítica, prática, enunciativa, e analítica da loucura ${ }^{49}$.

E mais ainda, posso a partir desse novo campo de visibilidade aberto pela leitura do trágico em Nietzsche, retomar este texto de Foucault, em outro campo de entendimento, para além das inúmeras críticas que pesaram intensamente sobre ele, como relata Roudinesco, referindo-se a esta injuriosa onda desabonadora que se abateu sobre Foucault:

(...) tinha literalmente inventado aquela famosa "cena primitiva" da divisão primordial e sempre recorrente: divisão entre a desrazão e a loucura, divisão entre a loucura ameaçadora dos quadros de Bosh e a loucura aprisionada do discurso de Erasmo, divisão entre uma consciência crítica, na qual a loucura se torna doença; e uma consciência trágica, na qual se torna criação, como em Goya, Van Gogh ou Artaud. Divisão, enfim, interna ao Cogito cartesiano, no qual a

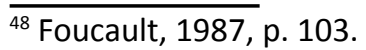

${ }^{49}$ Ibidem, p. 166-169 
loucura é excluída do pensamento no mesmo instante em que deixa de pôr em risco os direitos do pensamento. ${ }^{50}$

A partir da vida trágica, posso refazer os percursos por este texto, encontrando outras possibilidades, inclusive mais fortemente propositivas do que imaginaram seus tantos adversários com suas acusações:

(...) assim como os psiquiatras, os historiadores da psicopatologia tiveram então a impressão de que essa "loucura", que eles não tinham visto nos arquivos e que Foucault parecia ter exumado num passe de mágica, decorria de uma construção literária brilhante mas irresponsável. Ela permanecia alheia à realidade do sofrimento dos verdadeiros doentes que os psiquiatras tinham a seu cargo, cuja triste epopéia os historiadores tinham por tarefa relatar. E, por causa disso, ganhou força essa ideia de que Foucault não era nem médico, nem psiquiatra, nem psicólogo, e que ele jamais se encontrara com verdadeiros loucos de asilo. Com que direito ousava transformar a loucura anônima dos verdadeiros loucos em um afresco sublime? Em que o louco comum do asilo comum se pareceria com um Artaud, um Van Gogh? Parece que Foucault, disseram, se diverte zombando dos honestos funcionários hospitalares, que todos os dias têm de enfrentar loucos de camisa-de-força. ${ }^{51}$

É também pela lente do trágico que posso repensar não apenas esta obra, mas seu próprio autor, que para certa crítica, merecia ser desqualificado porque já havia tentado antes o suicídio, era homossexual, tentou submeter-se à análise sem sucesso, não quis seguir uma carreira nas profissões da saúde, apesar do pai médico, tampouco

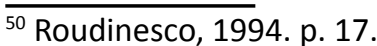

${ }^{51}$ Ibidem, p. 17. 
era reconhecido pela maioria dos historiadores como legitimamente um de seus pares, e entre os filósofos não eram poucas suas restrições, chegando a ser acusado "de ser ao mesmo tempo obscurantista e antidemocrata." 52

Também entre os militantes de vários setores da esquerda francesa era considerado quase uma aberração, entre muitos marxistas era tido como revisionista e capitulado, os psicanalistas o tinham em absoluta reserva, e, mesmo seu amigo pessoal, Jacques Derrida, Ihe direcionou uma obstinada crítica "sobre o estatuto do Cogito cartesiano em relação à história da loucura" ${ }^{\prime \prime 53}$, acusando-o de "uma interpretação excessivamente restritiva, porque excessivamente estruturalista, do sistema das divisões." ${ }^{154}$

Ou seja, é pela lente da tragicidade que se descortina para mim, um novo horizonte de leitura desta obra de Foucault (Foucault, 1987). Leitura não apenas nova, ou mais uma possível, mas uma leitura que potencializa e amplifica as possibilidades de desdobramentos no cotidiano dos serviços de saúde mental. Atualizando seus efeitos no movimento de construção de estratégias e táticas, em busca de formas de produzir cuidado em saúde mental, que tragam essa dimensão trágica, para além das dimensões crítica, prática, enunciativa e analítica da loucura (dimensões que a reduziram à doença mental).

Ou ainda, segundo os propósitos explicitados pelo próprio Foucault, pela lente da tragicidade, sua obra pode atuar mais vivamente nos serviços de saúde mental, para torná-los "capazes de oposição e de luta contra a coerção de um discurso teórico unitário, formal e científico." ${ }^{155}$

E nos tempos que correm, somos cada vez mais

\footnotetext{
${ }^{52}$ Roudinesco, 1994, p. 28.

53 Ibidem, p. 29.

54 Ibidem, p. 3.

${ }^{55}$ Foucault, 2005. p. 15.
} 
testemunhos do império deste discurso unitário, que torna urgente a retomada de obras que, como vislumbrava Foucault, permitam "a constituição de um saber histórico das lutas e a utilização desse saber nas táticas atuais."

Cabe lembrar por fim, perante as críticas que desqualificaram esta obra aqui retomada, que o projeto que a animava era o da "insurreição dos saberes" ${ }^{57}$, era justamente o das "anticiências" 58 , contra a hierarquização científica do conhecimento.

Encerro esta digressão que pretende, acima de tudo, registrar esse primeiro efeito, que testemunho em mim mesmo, desta tragicidade como conceito operatório.

E retomo o propósito de percorrer a formulação da governamentalidade, seu desdobramento pela tragicamentalidade, e a aplicação destes conceitosferramentas às três clínicas da saúde mental.

Pode-se perceber, então, que, este tema do trágico, terá aqui uma total centralidade. Saltando das páginas da "História da Loucura", iremos reencontrá-lo neste texto, também inaugural, da produção teórica de Nietzsche: "A Origem da Tragédia."

Publicado quase cem anos antes do texto de Foucault, nesta obra reconhecemos sua distinção primordial entre uma concepção trágica da vida, que contemple tanto o dionisíaco quanto o apolíneo, em oposição a uma estética socrática, que nega o dionisíaco, retendo apenas a dimensão apolínea da existência.

Buscarei então rever esta discussão de uma estética do trágico, e suas repercussões sobre uma abordagem da vida e do viver, retomando alguns dos caminhos de uma

${ }^{56}$ Foucault, 2005, p. 13.

${ }^{57}$ Ibidem, p. 14.

${ }^{58}$ Ibidem, p. 14. 
filosofia do trágico.

Para pensar esta estética do trágico, procederei também a uma brevíssima e sucinta discussão sobre a estética, entendida em seu sentido mais amplo, da vida como plenamente sensível.

Será com esta compreensão de estética, de acordo com certa tradição da filosofia do trágico, que poderei falar em dimensão estética do agir em saúde, podendo estabelecer a concepção do trágico na produção do cuidado.

Mas antes e primeiro, revisito este conceitoferramenta da governamentalidade, ao longo do ensino de Foucault, como anunciado acima, para que possa ir emergindo, em seguida e a partir deste, esse outro conceitoferramenta da tragicamentalidade. 


\section{II - Governamentalidade}

Antes de entrar propriamentena governamentalidade, me permito um prelúdio, partindo desta perda da consciência trágica da loucura, apontada por Foucault como constitutiva do nascimento da psiquiatria, da medicina mental.

Mas como dimensionar a importância deste tema do trágico na obra de Foucault?

Considerando, por exemplo, a expressiva sistematização da obra de Foucault organizada por Edgardo Castro ${ }^{59}$, em um louvável esforço de produção de um vocabulário de Foucault, diremos que este tema tem importância mínima, pois nem sequer o encontraremos ali.

Entre centenas de temas, não encontramos o trágico ou a tragédia, e nem mesmo uma referência direta a sua ligação com a obra inaugural de Nietzsche, quando este é amplamente abordado como tema e influência na obra de Foucault ${ }^{60}$.

Da mesma forma, se recorremos ao vocabulário organizado por Judith Revel, professora do Centro Michel

\footnotetext{
${ }^{59}$ Castro, 2009.

${ }^{60} \mathrm{Ibidem}$, p. 305-309.
} 
Foucault (Paris), em seu "Michel Foucault Conceitos Essenciais" ${ }^{\prime \prime}$, não encontramos este conceito de trágico ou tragédia, confirmando que, ao menos para estes estudiosos, este tema deve ser relegado a segundo plano.

Mas, por outro lado, o trágico ganha a maior relevância, se o tomamos como absolutamente representativo do que antecede a ruptura, caracterizada por Foucault, como constitutiva da psiquiatria; se consideramos a psiquiatria, por sua vez, não apenas como um interesse em si mesmo, mas como representativa deste movimento de criação da nova mentalidade, sensibilidade social, pertinente à modernidade ocidental. E se considerarmos ainda, este período de mudança, como inaugural deste processo de formação societária que inclui os momentos que serão denominados, de forma marcante e reveladora, como "sociedade carcerária"62, "sociedade disciplinar"63, "sociedade de controle". ${ }^{64}$

Teremos, enfim, uma íntima relação entre, por um lado, a descrição dos jogos de poder/saber constitutivos da psiquiatria, da medicina mental, como uma prática, um exercício social específico; e, por outro lado, uma tecnologia bem mais geral de poder, que Foucault nomeará posteriormente em sua obra, como governamentalidade.

Esta linha de raciocínio nos leva, portanto, a considerarmos este tema do trágico como um avesso desta tecnologia geral de poder denominada, em seu seminário de 1978 no Collège de France, de governamentalidade, e desta governamentalidade específica, que ele denomina biopolítica, na era do liberalismo, e também do neoliberalismo.

\footnotetext{
61 Revel, 2005.

62 Foucault, 2002.

63 Ibidem.

${ }^{64}$ Deleuze, 2007.
} 
Encontramos a indicação desta aproximação na aula de 08 de fevereiro de 1978:

\begin{abstract}
"Será que é possível repor o Estado moderno numa tecnologia geral de poder que teria possibilitado suas mutações, seu desenvolvimento, seu funcionamento? Será que se pode falar de algo como uma 'governamentalidade', que seria para o Estado o que as técnicas de segregação eram para a psiquiatria, o que as técnicas da disciplina eram para o sistema penal, o que a biopolítica era para as instituições médicas? Eis um pouco o objeto [deste curso]."65
\end{abstract}

Chegamos então a este ponto de aproximação, de interesse pelo trágico, que passa a ser, de um tema negligenciado no estudo da obra de Foucault, a uma via de importância capital para percorrer um avesso da governamentalidade.

E esta importância se torna ainda mais significativa quando pensamos em dois aspectos relevantes: primeiro, as dificuldades de abordagem que o tema da governamentalidade apresenta em si mesmo, necessitando de múltiplas estratégias para seu entendimento; e, segundo, a força centrípeta deste conceito, que faz girar em torno de si, boa parte do ensino de Foucault.

Quanto ao primeiro aspecto, que faz valorizar ainda mais uma possível abordagem deste conceito pela via de um avesso, é o próprio Foucault que ressalta a nebulosidade conceitual na qual mergulhamos com a governamentalidade, quando declara ainda nesta aula de 08 de fevereiro de 1978:

“(...) por que querer estudar esse domínio, no fim das contas inconsistente, nebuloso,

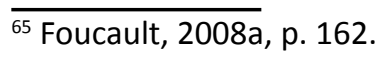


cingido por uma noção tão problemática e artificial quanto a de 'governamentalidade'? (...) por que querer abordá-lo através de uma noção que é plena e inteiramente obscura, a de 'governamentalidade'? Por que atacar o forte e o denso com o fraco, o difuso e o lacunar?"66

Quanto ao segundo aspecto, a força centrípeta, ou o campo magnético ou gravitacional deste conceito na obra de Foucault, por ser bem mais problemático, será necessário me estender um pouco mais, pois passo a apresentar aqui, em uma perspectiva não metódica, a suposição da implicação deste conceito com boa parte das pesquisas desenvolvidas por Foucault, mesmo antes da criação conceitual propriamente dita da governamentalidade. Ou seja, é dizer que as pesquisas de Foucault, inclusive as que antecedem este conceito, caminham em sua direção.

Com isto, quero tentar demonstrar que, a governamentalidade seria um conceito dos mais preciosos e significativos na obra de Foucault. $E$ que podemos reconhecê-lo como tema transversal ou subjacente, senão em toda sua obra, pelo menos ao longo do seu ensino no Collège de France.

Com isto, quero dizer que, ao rastrear este conceito, e suas origens, nestes cursos, já teremos algo absolutamente representativo, de sua importância, dentro do que pode ser chamado, o "conjunto dos 'atos filosóficos' efetuados por Michel Foucault." 67

Isto se confirma, ao lembrarmos que, Foucault assumiu a cadeira de "História dos Sistemas de Pensamento" no Collége de France em 1970, aos 43 anos, mantendo seus cursos ali até a sua morte em 1984. Portanto, sendo ali que

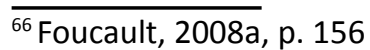

${ }^{67}$ Ewald; Fontana, 2005, p. XII. 
constituiu um importante núcleo de atividades de pesquisa e ensino, e onde desenvolveu sua genealogia das relações poder/saber, em oposição a uma arqueologia das formações discursivas, de que até então vinha se ocupando. ${ }^{68}$

Começo então pelo curso no qual o conceito propriamente dito de governamentalidade surgirá, o seminário de 1977-1978, intitulado "Segurança, Território, População", quando na aula de $1^{\circ}$ de fevereiro de 1978 declara:

“Por esta palavra, 'governamentalidade', entendo 0 conjunto constituído pelas instituições, os procedimentos, análises e reflexões, os cálculos e as táticas que permitem exercer esta forma bem específica, embora muito complexa, de poder que tem por alvo principal a população, por principal forma de saber a economia política e por instrumento técnico essencial os dispositivos de segurança. Em segundo lugar, por 'governamentalidade' entendo a tendência, a linha de força que, em todo o Ocidente, não parou de conduzir, e desde há muito, para a preeminência desse tipo de poder que podemos chamar de 'governo' sobre todos os outros - soberania, disciplina - e que trouxe, por um lado, o desenvolvimento de toda uma série de aparelhos específicos de governo [e, por outro lado]*, o desenvolvimento de toda uma série de saberes. Enfim, por 'governamentalidade', creio que se deveria entender o processo, ou antes, o resultado do processo pelo qual o Estado de justiça da Idade Média, que nos séculos XV e XVI se tornou o Estado administrativo, viu-se pouco a pouco 'governamentalizado'."69 
Temos aqui, neste momento do curso, um evidente esforço conceitual, um verdadeiro 'trabalho de parto', no qual Foucault tenta dar contornos ao seu nebuloso conceito, e, neste esforço, encontramos alguns importantes elementos que vale a pena destacar.

Em primeiro lugar, encontramos aqui inúmeros elementos que constituem, em si, campos de interesse para a pesquisa de Foucault, que extrapolam, em muito, o escopo deste curso de 78, como os conceitos de dispositivos de segurança, governo, Estado, população, soberania, disciplina, poder, tática, saber.

Em segundo lugar, vale ressaltar a amplitude do conceito, que se subdivide em três partes; sendo a primeira este conjunto de instituições, análises, reflexões, táticas que permitem exercer esta forma de poder que tem por alvo a população, por saber a economia política, por instrumento os dispositivos de segurança. Sendo a segunda, esta linha de força, operando em todo o ocidente, deslocando o regime de poder do soberano, do disciplinar, para o poder de governo, com seus aparelhos específicos e os saberes que Ihe são próprios. E a terceira, esta governamentalização do Estado.

Estamos pois, no centro do que é reconhecido como sendo a segunda fase dos cursos de Foucault, constituída pelos cursos "Em Defesa de Sociedade" (75-76), "Segurança, Território, População" (77-78), "Nascimento da Biopolítica" (78-79), Do Governo dos Vivos" (79-80).

Antes desta, temos a fase dos cursos cujo eixo de trabalho foi a genealogia das disciplinas, com "A Vontade de Saber" (70-71), "Teorias e Instituições Penais" (71-72), "A Sociedade Punitiva" (72-73), “O Poder Psiquiátrico" (7374), "Os Anormais" (74-75); e que serviram de material para seus livros "Vigiar e Punir" e "A Vontade de Saber". 
E depois, temos a terceira fase, quando predomina a investigação sobreas formas de subjetivação, entrecruzandose com a questão do governar, a si e aos outros, com os cursos "Subjetividade e Verdade" (80-81), "A Hermenêutica do Sujeito" (81-82), "O Governo de Si e dos Outros" (82-83), "O Governo de Si e dos Outros: A Coragem da Verdade" (8384); que serviram de material para a redação dos volumes II e III da História da Sexualidade. ${ }^{70}$

Podemos ver como, portanto, este conceito de governamentalidade ocupa, literalmente, temporalmente, uma posição de centralidade no ensino de Foucault, com seis cursos que serão oferecidos antes, e seis cursos que serão oferecidos depois deste seu "Segurança, Território, População".

E também dentro deste curso, é notável como os conceitos de dispositivos de segurança, governo, população, razão de Estado, e outros; giram em torno da noção de governamentalidade, gravitando em sua órbita.

Foucault assimila neste conceito, como descrito acima, sua noção tão singular de poder, como profundamente relacional e interativo, produtivo, e em ato; sendo a governamentalidade este conjunto (reflexões, análises, instituições, táticas, cálculos, procedimentos) que permite e sustenta o exercício de uma forma bem específica e complexa de poder.

Então, por um lado, podemos entender, que a governamentalidade é, ela mesma, uma forma de poder. E, por outro lado, podemos entender que ela não é uma forma de poder, como o são o poder pastoral, o poder soberano, o poder disciplinar, mas um conjunto que viabiliza uma forma de poder.

$\overline{{ }^{70} \text { Castro, 2009, p } 188-189 .}$ 
E esta forma de poder viabilizada, ou seja, referente à governamentalidade, é aquele poder que tem por alvo preferencial a população, por forma de saber, a economia política, e por instrumento técnico, os dispositivos de segurança, e por máquina privilegiada, o Estado governamentalizado.

Temos aqui então, a conjunção, sempre presente em Foucault, entre forma de poder e forma de saber, que se conjugam, sem que se saiba exatamente da precedência de um ou de outro, sem reduzir-se a uma relação simplista causal, mas constituindo uma relação integrativa, interacionista.

Mas qual seria afinal o sobrenome deste poder referente à governamentalidade?

Para buscar esta resposta, vamos lembrar que na primeira fase de seus cursos, descrita acima, Foucault trabalhou, sobretudo, a questão das disciplinas, tomando por exemplar, a constituição da medicina mental; e descrevendo, nesta fase de seus cursos, também um poder específico, um poder chamado de disciplinar.

Poder este que também foi se constituindo, sempre, em relação a certas formas de saber, incluindo aí os saberes classificatórios, ordenatórios; e que possuía seus instrumentos técnicos, de vigilância dos indivíduos, de diagnósticos; e que representou, não uma superação, pois não se trata aqui de uma perspectiva evolucionista, mas uma sobreposição, ou uma superposição, que desqualifica o poder soberano, predominante até então.

Este poder, intensamente apontado na primeira fase dos cursos de Foucault, também apresenta, portanto, seus procedimentos específicos, seus saberes pertinentes, seus instrumentos de vigilância, seu alvo predominante de 
incidência sobre os corpos individuais (sua separação, seu alinhamento, sua colocação em série e vigilância), e sobre o que eles fazem. E que vão construindo a incompatibilidade com as relações de soberania, que o precederam. É, neste momento, a constituição do poder disciplinar.

Foucault declara em 1976 que vinha buscando desde 1970-1971, ou seja, desde o começo de seu ensino, "o como do poder". ${ }^{71} \mathrm{E}$ no final deste curso de 76, "Em Defesa da Sociedade", que inicia a segunda fase de seus cursos, apresenta esta nova reviravolta ao nível das tecnologias, dos mecanismos do poder:

"Ora, durante a segunda metade do século XVIII, eu creio que se vê aparecer algo de novo, que é uma outra tecnologia de poder, não disciplinar dessa feita. Uma tecnologia de poder que não exclui a primeira, que não exclui a técnica disciplinar, mas que a embute, que a integra, que a modifica parcialmente e que, sobretudo, vai utilizá-la implantandose de certo modo nela, e incrustando-se efetivamente graças a essa técnica disciplinar prévia. Essa nova técnica não suprime a técnica disciplinar simplesmente porque é de outro nível, está noutra escala, tem outra superfície de suporte e é auxiliada por instrumentos totalmente diferentes."72

Encontramos enfim, em seguida, a resposta ao sobrenome deste poder que é o referente à governamentalidade:

“(...) Depois da anátomo-política do corpo
humano, instaurada no decorrer do século
XVIII, vemos aparecer, no fim do mesmo
século, algo que já não é uma anátomo-
política do corpo humano, mas que eu

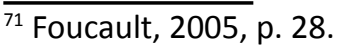

${ }^{72}$ Ibidem, p. 288-289. 
chamaria de uma 'biopolítica' da espécie humana.

De que se trata nessa nova tecnologia do poder, nessa biopolítica, nesse biopoder que está se instalando? Eu Ihes dizia em duas palavras agora há pouco: trata-se de um conjunto de processos como a proporção dos nascimentos e dos óbitos, a taxa de reprodução, a fecundidade de uma população, etc."73

Aí está, a governamentalidade é um conjunto que permite o exercício desta forma específica de poder, o biopoder, é o que diz Foucault, em sua última aula do curso de 1976, antecipando o que viria a seguir, em seu próximo curso:

“(...) Dizer que o poder, no século XIX, tomou posse da vida, dizer pelo menos que o poder, no século XIX, incumbiu-se da vida, é dizer que ele conseguiu cobrir toda a superfície que se estende do orgânico ao biológico, do corpo à população, mediante o jogo duplo das tecnologias de disciplina, de uma parte, e das tecnologias de regulamentação, de outra.

Portanto, estamos num poder que se incumbiu tanto do corpo quanto da vida, ou que se incumbiu, se vocês preferirem, da vida em geral, com o pólo do corpo e o pólo da população. Biopoder, por conseguinte, do qual logo podemos localizar os paradoxos que aparecem no próprio limite de seu exercício." ${ }^{74}$

Temos a confirmação dessa ligação entre governamentalidade, como sustentáculo do biopoder, também logo na primeira aula, nas primeiras palavras deste

\footnotetext{
${ }_{73}^{73}$ Foucault, 2005, p. 289-290.

${ }^{74}$ Ibidem, p. 302
} 
curso que se seguiu, em 11 de janeiro de 1978:

\begin{abstract}
"Este ano gostaria de começar o estudo de algo que eu havia chamado, um pouco no ar, de biopoder, isto é, essa série de fenômenos que me parece bastante importante, a saber, o conjunto dos mecanismos pelos quais aquilo que, na espécie humana, constitui suas características biológicas fundamentais vai poder entrar numa política, numa estratégia política, numa estratégia geral de poder." ${ }^{175}$
\end{abstract}

Então, retomando aquele esforço conceitual a propósito da governamentalidade, temos que esta é o conjunto de relações, saberes, estratégias, táticas, instituições, que permitem, viabilizam, sustentam o exercício do biopoder; tendo por alvo principal a população, por saber predominante a economia política, por instrumento técnico essencial, os dispositivos de segurança. Com a proeminência do governo, da regulamentação, sobre a soberania ou a disciplina, e com a transformação do Estado de justiça da idade média, e do Estado administrativo dos séculos XV e XVI, no Estado governamental.

Mas, se parece agora mais delimitado tal conceito, convém perceber suas origens ou ramificações em outros cursos de Foucault que não apenas estes dois que acabamos de abordar aqui, e que são os que lhe dizem respeito mais diretamente.

Retomando então os cursos que antecedem estes apresentados, convém recordar logo de imediato que, como afirma Foucault, a governamentalidade é uma estratégia que se realiza em um jogo duplo, uma somatória das estratégias das disciplinas e das estratégias da regulamentação. Donde concluímos, para começar, que toda a formação das disciplinas, foco das pesquisas anteriores, já participa, desta

$\overline{75}$ Foucault, 2008, p. 4 
forma, do processo que culminará no estabelecimento da governamentalidade.

Neste sentido, uma primeira aproximação possível é entre a construção do conceito de práticas discursivas, como pressuposto de uma microfísica do poder, que permitirá chegar ao biopoder, e portanto, à governamentalidade.

No seminário de 1970-71 a propósito da "Vontade de Saber", Foucault se detém sobre as práticas discursivas, como um dos pontos cruciais. E, a psiquiatria aparece justamente como pertinente a estas práticas discursivas, uma vez que

“(...) caracterizam-se pelo recorte de um campo de projetos, pela definição de uma perspectiva legítima para o sujeito de conhecimento, pela fixação de normas para a elaboração de conceitos e teorias. Cada uma delas supõe, então, um jogo de prescrições que determinam exclusões e escolhas." ${ }^{\prime 16}$

E ainda:

"As práticas discursivas não são pura e simplesmente modos de fabricação de discursos. Ganham corpo em conjuntos técnicos, em instituições, em esquemas de comportamento, em tipos de transmissão e de difusão, em formas pedagógicas, que ao mesmo tempo as impõem e as mantêm.".77

E, finalmente:

"Estudos empíricos sobre psicopatologia, sobre a medicina clínica, sobre a história natural etc. haviam permitido isolar o nível das práticas discursivas. As características gerais dessas práticas e os métodos próprios

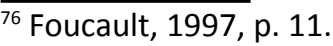

${ }^{77}$ Ibidem, p. 12. 
para analisá-las haviam sido inventariados sob o nome de arqueologia."78

Já no seminário de 1971-72, "Teorias e Instituições Penais", encontramos, como precedentes desta formação conceitual da governamentalidade, a análise do desenvolvimento do aparelho policial, a vigilância das populações, no século XVIII, como a preparação e gestação de um novo tipo de poder-saber que se efetivará somente no século $\mathrm{XIX}{ }^{79}$

Ainda neste curso, encontramos também a noção fundamental, preparatória, de sociedade "inquisitorial":

"Pertencemos a uma civilização inquisitória, que há séculos pratica, segundo formas cada vez mais complexas, porém todas derivadas do mesmo modelo, a extração, o deslocamento, o acúmulo do saber. A inquisição: forma de poder-saber essencial à nossa sociedade." ${ }^{80}$

No curso de 1972-1973, "A Sociedade Punitiva", já encontramos mais referências à constituição do poder disciplinar, através da descrição da composição desta sociedade carcerária, que é parte integrante do projeto de uma "civilização da vigilância", que integra, em um Estado centralizado, mecanismos de controle e vigilância.

Acompanhamos a formação de uma sociedade carcerária onde:

“-A reclusão intervém também no que diz respeito à conduta dos indivíduos. Sanciona, num nível infrapenal, maneiras de viver, tipos de discursos, projetos ou intenções políticas, comportamentos sexuais, reações à autoridade, bravatas à opinião, violências, etc. Em suma, intervém menos em nome da lei do

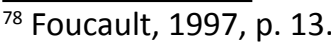

79 Ibidem, p. 22.

${ }^{80}$ Ibidem, p. 22. 
que em nome da ordem e da regularidade. O irregular, o agitado, o perigoso e o infame são objeto da reclusão. Enquanto que a penalidade pune a infração, a reclusão, por sua vez, sanciona a desordem."81

Percebe-se, portanto, a preparação do terreno onde se assentará, coerentemente, a junção das disciplinas e da regulamentação. E esta preparação é colocada como um capítulo na "história do corpo"; e "uma questão de física", física do poder, com sua ótica, órgão da vigilância generalizada, sua mecânica do isolamento, agrupamento, sua fisiologia das normas.

Esta aproximação fica ainda mais evidente ao lembrarmos que, na aula de 24 de janeiro de 1979, portanto, seis anos depois, Foucault retoma o tema, tão caro à sociedade carcerária, do panóptico de Bentham, para delinear a arte liberal de governar:

"Segunda conseqüência desse liberalismo e dessa arte liberal de governar é a formidável extensão dos procedimentos de controle, de pressão, de coerção que vão constituir como que a contrapartida e o contrapeso das liberdades." 82

Nesta mesma aula de 1979, Foucault chegará a dizer, referindo-se a Bentham, que "o panóptico é a própria fórmula de um governo liberal", portanto, intimamente relacionado a esta forma de governamentalidade, constituída pela biopolítica.

Portanto, neste curso de 1972-1973 já temos a referência direta à sociedade da disciplina e da normalização, que só se intensificará no curso seguinte, de 1973-1974, “O Poder Psiquiátrico".

\footnotetext{
${ }^{81}$ Foucault, 1997, p. 36.

${ }^{82}$ Foucault, 2008a, p. 91.
} 
Chegamos então a este que é um dos cursos de maior interesse para este estudo, já que, como esclarecido acima, este rastreamento do conceito de governamentalidade vincula-se ao esclarecimento da ruptura, da perda da experiência trágica, descrita por Foucault, em sua "História da Loucura".

Pois este "O Poder psiquiátrico" se propõe a ser, como declarado na aula de 07 de novembro de 1973, o "segundo volume" da História da Loucura, porém, com uma análise radicalmente diferente, que pretende abandonar o núcleo representativo que remete necessariamente a uma história das mentalidades, em favor de, ressaltando, os dispositivos de poder.

E isto, na medida em que tais dispositivos de poder podem ser produtores de enunciados, produtores de práticas discursivas, produtores de formas de subjetivação, e também, de resistências.

Como se vê, retorna aqui o tema das práticas discursivas, presente desde o primeiro curso de 1970, e, na verdade, presente desde sua aula inaugural no Collége de France, pronunciada em 02 de dezembro de 1970, intitulada "A Ordem do Discurso", quando refere que:

"Os discursos devem ser tratados como
práticas descontínuas, que se cruzam por
vezes, mas também se ignoram ou se
excluem." ${ }^{33}$

É nesta perspectiva das práticas discursivas que Foucault buscará investigar neste curso as relações entre dispositivo de poder e dispositivo de verdade, e suas inscrições no corpo, uma vez que, "há entre o corpo e o poder político uma ligação direta." ${ }^{84}$

${ }^{83}$ Foucault, 1996, p. 52-53.

${ }^{84}$ Foucault, 2006a, p. 19. 
Estamos então plenamente na discussão do exercício do poder sobre o corpo, na discussão da anátomo-política, do poder disciplinar, que precedem a biopolítica e 0 biopoder, mas que irão se encontrar, de forma integrativa, na composição da governamentalidade.

Foucault volta ainda a insistir, não apenas que este seu curso é o segundo volume, mas, até, uma oportunidade de retificar a "História da Loucura". ${ }^{55} \mathrm{E}$ que ele pode declarar, agora com mais clareza, que não é a instituição que determina as relações de poder, tampouco é um discurso de verdade, e nem mesmo o modelo familiar, quando se trata da emergência do poder disciplinar em sua microfísica.

Temos, nesta altura de sua obra, indivíduo como "um corpo sujeitado, pego num sistema de vigilância $e$ submetido a procedimentos de normalização" tempo que, nesta constituição da sociedade disciplinar, a função-psi passa a ser "a instância de controle de todas as instituições e de todos os dispositivos disciplinares." ${ }^{187}$

Esta função-psi, esclarece Foucault,

"é, a função psiquiátrica, psicopatológica,
psicossociológica, psicocriminológica,
psicanalítica, etc. E, quando digo 'função',
entendo não apenas o discurso mas
a instituição, mas o próprio indivíduo
psicológico. Ecreio que é essa a função desses
psicólogos, psicoterapeutas, criminologistas,
psicanalistas, etc.; qual é ela, senão ser os
agentes da organização de um dispositivo
disciplinar que vai se ligar, se precipitar onde
se produz um hiato na soberania familiar?"

\footnotetext{
${ }_{85}$ Foucault, 2006a, p. 33.

${ }^{86}$ Ibidem, p. 71.

87 Ibidem, p. 107.

${ }^{88} \mathrm{Ibidem}$, p. $105-106$.
} 
Foucault descreve pormenorizadamente como os chamados métodos terapêuticos psiquiátricos funcionam apenas para que "o mecanismo da ordem e da obediência seja absolutamente engrenado." ${ }^{\prime 89}$, de forma que, esse exercício de poder psiquiátrico representa uma maneira de gerir e de administrar, antes que uma intervenção terapêutica, sendo assim um verdadeiro regime.

$E$, mais do que isto, a atenção de Foucault se volta para o momento em que o poder psiquiátrico sai dos asilos, e vai além:

\begin{abstract}
"uma espécie de difusão, de migração desse poder psiquiátrico, que se difundiu em certo número de instituições, de outros regimes disciplinares a que ele veio, de certo modo, se adicionar. Em outras palavras, creio que o poder psiquiátrico como tática de sujeição dos corpos numa certa física do poder, como poder de intensificação da realidade, como constituição dos indivíduos ao mesmo tempo receptores e portadores de realidade, se disseminou." 90
\end{abstract}

É exatamente este ponto de disseminação que será abordado no curso seguinte, de 1974-1975, "Os Anormais", dando seqüencia a esta mesma descrição do poder disciplinar, encaminhando-se gradualmente em direção à governamentalidade.

Já no curso de 1973-1974, Foucault antecipara a profunda difusão do poder psiquiátrico em nossa sociedade, convertendo um fato de assistência num fenômeno de proteção, através das noções de periculosidade, de anormalidade, de comportamento automático, e outras; que ele agora aprofunda e desvenda.

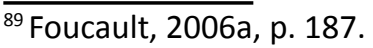

${ }^{90}$ Ibidem, p. 236. 
Este curso, "Os Anormais", é especialmente instrutivo para a compreensão da formação da governamentalidade, porque demonstra esta mutação ocorrendo no interior mesmo das práticas psiquiátricas, através do reposicionamento da psiquiatria na trama das relações de força, constituintes de uma lógica de funcionamento do poder, cuja mudança podemos acompanhar da maneira mais evidente neste curso.

É assim que Foucault vai demonstrando como podemos enxergar esta mudança, esta ascensão de uma nova arquitetura, nova inserção do poder, em seus três aspectos, através do modelo exemplar da psiquiatria.

Recordando então esses três aspectos descritos acima, vemos que na idade da governamentalidade, primeiro, a psiquiatria sofre uma mutação de seu alvo, que deixa de ser sua inserção diretamente voltada para disciplinar o corpo, passando a ser a população.

Em segundo lugar, a psiquiatria experimenta uma mudança de seu saber, que deixa de ser centrado na doença, nos doentes, na exceção, para se voltar para a totalidade dos homens, através da psiquiatrização da infância, que é um atributo universal, através da psiquiatrização do comportamento, da psiquiatrização da desadaptação, da incongruência social; da psiquiatrização do instinto e da sexualidade, de uma forma que, agora, é o conjunto da espécie humana que diz respeito à psiquiatria, e não apenas o seleto grupo dos doentes mentais, da loucura.

Em terceiro lugar, acompanhamos a mudança nos instrumentos técnicos que viabilizam e solidarizam com as outras duas, e a psiquiatria já não se restringe mais ao espaço asilar, com suas tecnologias de funcionamento, mas encontra-se agora na família, na escola, difusamente no tecido social, em mecanismos jurídicos, pedagógicos e 
terapêuticos, mas já sem seu antigo compromisso com a cura, uma vez que, não tem mais seu antigo compromisso com a doença.

Em sua nova dimensionalidade, a psiquiatria, já muito além do poder disciplinar, apresenta de forma cada vez mais forte, seu compromisso com a segurança pública, seu compromisso com a proteção social, seu compromisso com o planejamento estatal, com a regulamentação governamental, estabelecida na Idade Clássica, como explica Foucault:

"A Idade Clássica, portanto, elaborou o que podemos chamar de uma "arte de governar", precisamente no sentido em que se entendia, nessa época, o 'governo' das crianças, o 'governo' dos loucos, o 'governo' dos pobres e, logo depois, o 'governo' dos operários. E por 'governo' cumpre entender, tomando o termo no senso lato, três coisas. Primeiro, é claro, o século XVIII, ou a Idade Clássica, inventou uma teoria jurídico-política do poder, centrada na noção de vontade, na sua alienação, na sua transferência, na sua representação num aparelho governamental. O século XVIII, ou a Idade Clássica, implantou todo um aparelho de Estado, com seus prolongamentos e seus apoios em diversas instituições. E depois - é nisso que gostaria de me deter um pouquinho, ou deveria servir de pano de fundo para a análise da normalização da sexualidade - ele aperfeiçoou uma técnica geral de exercício do poder, técnica transferível a numerosas e diversas instituições e aparelhos." ${ }^{\prime 1}$

Neste curso, vai ficando cada vez mais transparente a generalização da psiquiatria como poder social, uma vez que:

$\overline{{ }^{91} \text { Foucault, } 2001,}$ p. $60-61$. 
"Essa transformação permitiu, no fundo, um
intenso processo que não está concluído em
nossos dias, o processo que fez que o poder
psiquiátrico intramanicomial, centrado na
doença, pudesse se tornar uma jurisdição
geral intra e extramanicomial, não da loucura,
mas do anormal e de toda conduta anormal."92

Após este curso seguiram-se os cursos "Em Defesa da Sociedade" de 1975-1976, e "Segurança, Território, População", de 1977-1978 (portanto, depois de um ano sabático), já comentados acima, por serem os mais diretamente relacionados à formulação da governamentalidade.

Em seguida, temos o curso "Nascimento da Biopolítica", 1978-1979, no qual Foucault dará seguimento e desdobramento ao estudo da governamentalidade:

“O próprio termo 'poder' não faz mais que designar um [campo]* de relações que tem de ser analisado por inteiro, e o que propus de chamar de governamentalidade, isto é, a maneira como se conduz a conduta dos homens, não é mais que uma proposta de grade de análise para essas relações de poder.

Tratava-se portanto de testar essa noção de governamentalidade e tratava-se, em segundo lugar, de ver como essa grade da governamentalidade - podemos supor que ela é válida quando se trata de analisar a maneira como se conduz a conduta dos loucos, dos doentes, dos delinquentes, das crianças -, como essa grade da governamentalidade também pode valer quando se trata de abordar fenômenos de outra escala, como por exemplo uma política econômica, como a gestão de todo um corpo social, etc. O que eu queria fazer

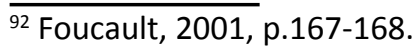


- e era esse o objeto da análise - era ver em que medida se podia admitir que a análise dos micropoderes ou dos procedimentos da governamentalidade não está, por definição, limitada a uma área precisa, que seria definida por um setor de escala, mas deve ser considerada simplesmente um ponto de vista, um método de decifração que pode ser válido para a escala inteira, qualquer que seja a sua grandeza." ${ }^{\prime 3}$

Esta definição preciosa nos ajuda, em primeiro lugar, a esclarecer, mais ainda, esta proximidade da governamentalidade com a condução da conduta dos homens, lançando então, uma conexão com o ensino de Foucault nos anos que se seguiram, e nos quais se dedicou muito ao governo dos vivos, de si, dos outros.

E, em segundo lugar, esta definição aponta para a governamentalidade como lançando uma particular visibilidade sobre a microfísica do poder, sobre a micropolítica e suas conexões com a macropolítica, que não seriam, como dito acima, uma questão de setores distintos de escala, ou seja, não referindo-se ao grande e ao pequeno; mas uma questão de ponto de vista, que diz respeito à escala inteira, qualquer que seja a sua grandeza.

É também neste curso que Foucault se debruça sobre a governamentalidade especificamente nos tempos do neoliberalismo, pós 1930:

"Trata-se, ao contrário, de obter uma sociedade indexada, não na mercadoria e na uniformidade da mercadoria, mas na multiplicidade e na diferenciação das empresas.

Eis a primeira coisa que eu queria lhes dizer. A segunda - acho que não vou ter tempo agora -, segunda consequência desta arte liberal de

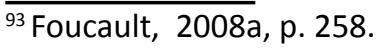


governar, [são] as modificações profundas no sistema da lei e na instituição jurídica."94

Desta forma, vamos descortinando as particularidades da governamentalidade no regime liberal contemporâneo, com sua "arte liberal de governar", com seu pressuposto de que "sempre se governa demais", constituindo a "Sociedade empresarial" descrita neste curso, andando passo a passo com a sociedade judiciária.

Desenvolve-se então a razão de estado mínimo:

“É essa multiplicação da forma 'empresa' no interior do corpo social que constitui, a meu ver, o escopo da política neoliberal. Trata-se de fazer do mercado, da concorrência e, por conseguinte, da empresa o que poderíamos chamar de poder enformador da sociedade."95

A governamentalidade neoliberal terá então, algumas peculiaridades, sendo cada vez mais regida pela racionalidade econômica, caminhando na direção de colocar a sociedade a serviço do mercado, tendo assim o:

\footnotetext{
"homo oeconomicus como parceiro, como vis-à-vis, como elemento de base da nova razão governamental tal como se formula no século XVIII." ${ }^{\prime 96}$
}

Em seguida, temos o curso "Do Governo dos Vivos", de 1979-1980, no qual Foucault dá prosseguimento às análises dos anos anteriores, sobre as "técnicas e procedimentos destinados a dirigir a conduta dos homens." 977 Contudo, observa-se um deslocamento importante na direção do resgate histórico do exame de consciência e da confissão, investigando-se os atos de obediência e de submissão, os "atos de verdade".

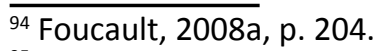

${ }^{95}$ Ibidem, p 203.

96 Ibidem, p. 370.

${ }^{97}$ Foucault, 1997, p. 101.
} 
Este deslocamento se aprofundará no curso seguinte, de 1980-1981, "Subjetividade e Verdade", no qual Foucault se debruça sobre as "técnicas de si", sobre as relações de domínio de si sobre si ou de conhecimento de si por si, recolocando o "conhece-te a ti mesmo", em um contexto mais amplo do "que fazer de si mesmo?"98

Foucault reconhece neste desvio a manutenção do tema da governamentalidade, agora em cruzamento com o tema da subjetividade:

"Um projeto como esse encontra-se no cruzamento de dois temas tratados anteriormente: uma história da subjetividade e uma análise das formas da 'governamentalidade'."'99

Deste cruzamento emergirá, gradualmente, a hermenêutica do sujeito, os processos de subjetivação:

\begin{abstract}
"Seria possível, assim, retomar num outro aspecto a questão da 'governamentalidade': o governo de si por si na sua articulação com as relações com o outro (como é encontrado na pedagogia, nos conselhos de conduta, na direção espiritual, na prescrição dos modelos de vida etc.)."100
\end{abstract}

Este mesmo tema do cuidado de si se desdobra, no curso seguinte, de 1981-1982, "A Hermenêutica do Sujeito", no tema da hermenêutica de si. Temos então um aprofundamento do afastamento dos temas anteriores, em direção à problemática entre subjetividade e verdade, e às técnicas de condução de si mesmo.

Mas, contudo, o tema da governamentalidade permanecerá sempre presente em seus cursos, ainda que

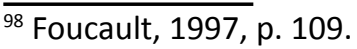

${ }^{99}$ Ibidem, p. 110.

${ }^{100}$ Ibidem, p. 111. 
com outros dimensionamentos, voltado cada vez mais para uma governamentalidade operante na relação consigo mesmo, nos processos constitutivos de subjetivações:

"Em outras palavras, se considerarmos a questãodo poder, dopoderpolítico, situando-a na questão mais geral da governamentalidade - entendida a governamentalidade como um campo estratégico de relações de poder, no sentido mais amplo do termo, e não meramente político, entendida pois como um campo estratégico de relações de poder no que elas têm de móvel, transformável, reversível -, então, a reflexão sobre a noção de governamentalidade, penso eu, não pode deixar de passar, teórica e praticamente, pelo âmbito de um sujeito que seria definido pela relação de si para consigo. Enquanto a teoria do poder político como instituição refere-se, ordinariamente, a uma concepção jurídica do sujeito de direito, parece-me que a análise da governamentalidade - isto é, a análise do poder como conjunto de relações reversíveis - deve referir-se a uma ética do sujeito definido pela relação de si para consigo. Isto significa muito simplesmente que, no tipo de análise que desde algum tempo busco lhes propor, devemos considerar que relações de poder/governamentalidade/governo de si e dos outros/relação de si para consigo compõem uma cadeia, uma trama e que é em torno destas noções que se pode, a meu ver, articular a questão da política e a questão da ética." 101

Este tema da relação consigo, da fabricação de si mesmo, enquanto espaço também de intervenção da governamentalidade, continuará em seus dois últimos cursos, "O Governo de Si e dos Outros", de 1982-1983, e "O

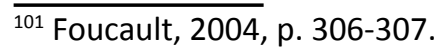


Governo de si e dos Outros II - A Coragem da Verdade", de 1983-1984.

Temos nestes últimos desdobramentos da governamentalidade, uma fundamental abertura, que permite repensar a questão da política e da ética como dito acima, mas também de uma ética-estética da existência, enquanto fabricação de si mesmo como campo de ação política, uma vez que:

“(...) afinal, não há outro ponto, primeiro e último, de resistência ao poder político senão na relação de si para consigo." ${ }^{102}$

Chegamos aqui, então, ao caro tema da resistência, comoaçãopolítica precedente, comotambém especialmente pertinente ao conceito de governamentalidade, como fica ainda mais claro, no manuscrito de Foucault, citado por Michel Senellart:

"A análise da governamentalidade como generalidade singular implica que 'tudo é político'. Dá-se tradicionalmente dois sentidos e essa expressão:

- O político se define por toda a esfera de intervenção do Estado [...] Dizer que tudo é político é dizer que o Estado está em toda parte, direta ou indiretamente.

- O político se define pela onipresença de uma luta entre dois adversários [...]. Essa outra definição é a de k. [sic] Schmitt.

A teoria do camarada.

$[\ldots]$

Em suma, duas formulações: tudo é político pela natureza das coisas; tudo é político pela existência dos adversários.

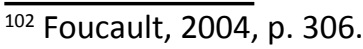


Trata-se, antes, de dizer: nada é político, tudo é politizável, tudo pode se tornar político. A política não é nada mais nada menos do que nasce com a resistência à governamentalidade, primeira sublevação, o primeiro enfrentamento." ${ }^{103}$

É justamente porque o estudo das formas de governamentalidade encontra-se indissociável da compreensão das formas de resistência que lhes correspondem, é que proponho avançar aqui na construção do conceito de tragicamentalidade.

Apesar de rápida e incompleta, acredito que esta passagem ao longo do ensino de Foucault no Collège de France é suficiente para demonstrar a importância capital deste conceito governamentalidade em seu pensamento, e a força de ligação que ele estabelece com os mais inúmeros temas que foram caros a Foucault ao longo de suas pesquisas.

Também considero suficientemente esclarecido o conceito de governamentalidade, tanto quanto sua ligação com uma série imensa de investigações que Foucault dedicou especificamente à psiquiatria, à medicina mental, que teve a sorte de ser um de seus objetos de estudo mais constantes.

Diante disto, cabe constatar que há uma prática clínica em saúde mental, há um exercício da psiquiatria enquanto prática social e discursiva, que está inserida em, participa de, certas formas de governamentalidade.

Ou ainda, a psiquiatria, a saúde mental é um dos subconjuntos de dispositivos, práticas, táticas, saberes que compõem a realização de certas formas de governamentalidade em ato.

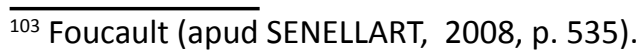


Este é, portanto, meu ponto de partida para o próximo passo na realização deste estudo, qual seja, a partir da governamentalidade, pensar um avesso possível, a tragicamentalidade. Para, em seguida, pensá-la referindose ao exercício da produção do cuidado, que, mesmo estando integrada ao exercício da clínica, não se limita, não se reduz a ela.

Em outras palavras, trata-se aqui de construir, não uma polarização maniqueista, mas o reconhecimento de uma dualidade possível, composta por dois referenciais, que estariam, de forma ambivalente, animando o trabalho vivo em ato, como apresentado acima, da produção do cuidado em saúde mental.

Estes dois referenciais sendo da ordem da dimensão ético-estética do agir em saúde. São eles a governamentalidade, como descrita por Foucault, e a tragicamentalidade, como tentarei descrever em seguida.

Antes, contudo, me permito ainda um comentário neste tópico, que diz respeito diretamente a esta aproximação, que acabo de fazer, da governamentalidade e as práticas de saúde.

É que, em sua aula de 10 de janeiro de 1979, portanto dentro do curso intitulado "Nascimento da Biopolítica", Foucault retoma o tema da "razão de Estado", que já havia trabalhado em seu curso um ano antes.

Nesta retomada, ele descreve a emergência de um certo tipo de racionalidade na prática governamental, que permitiria regrar a maneira de governar com base em algo que se chama Estado, e que, em relação a este cálculo governamental, exerce, ao mesmo tempo, o papel de um já dado, pois é verdade que o que se governará é um Estado que se apresenta como já existente; mas o Estado será, ao mesmo tempo, um objetivo a construir. 
Ou seja, o Estado é, ao mesmo tempo, o que já existe, e o que precisa ser construído. E, a razão de Estado será precisamente, uma racionalização de uma prática que vai se situar entre o Estado apresentado como dado e o Estado a ser construído.

A arte de governar então opera neste ínterim, racionalizando suas maneiras de fazer, de modo a, fazer 0 dever-ser do Estado tornar-se ser. $O$ dever-ser do governo deve se identificar com o dever-ser do Estado.

Ou ainda, a razão governamental é o que deverá possibilitar, de maneira calculada, que o Estado possa passar ao seu máximo de ser.

Retomo este ponto, por julgá-lo útil para pensarmos, seguindo um raciocínio equivalente, como o trabalho em saúde funciona dentro desta lógica da governamentalidade.

Então, construindo uma analogia com o que acabou de ser dito a propósito da razão de Estado, gostaria de pensar a razão da Clínica, e a produção da Saúde.

Analogamente, portanto, o que seria clinicar com a razão governamental?

Podemos pensar assim, a Saúde ocupa este lugar em relação a este cálculo governamental, no caso cálculo da Clínica, e exerce, ao mesmo tempo, o papel de um já dado, pois é verdade que o que se governará é a Saúde, que se apresenta como já existente; mas a Saúde será, ao mesmo tempo, um objetivo a construir.

Ou seja, a Saúde é, ao mesmo tempo, o que já existe, e o que precisa ser construído. E, a razão da Clínica será precisamente, uma racionalização de uma prática que vai se situar entre a Saúde apresentada como dado e a Saúde a ser construída. 
A arte de governar a Clínica opera neste ínterim, racionalizando suas maneiras de fazer, de modo a, fazer o dever-ser da Saúde tornar-se ser. O dever-ser da Clínica deve se identificar com o dever-ser da Saúde.

Ou ainda, a razão governamental-Clínica é o que deverá possibilitar, de maneira calculada, refletida, ponderada, que a Saúde possa passar ao seu máximo de ser.

De forma distinta, funcionará a produção do cuidado referida a uma tragicamentalidade. 



\section{III - Tragicamentalidade}

Passo agora ao desenvolvimento deste conceito tragicamentalidade, que figura neste estudo, como protagonista.

Ou talvez seja mais exato dizer que o papel da tragicamentalidade é aqui o de deuteragonista.

Deuteragonista enquanto 0 interlocutor, que permite ao protagonista revelar-se em sua distinção, em sua diferença. Ou seja, é através do deuteragonista, com sua função reveladora segunda, em geral em oposição ao protagonista, que podemos reconhecer o protagonismo do primeiro, e suas propriedades de herói trágico. ${ }^{104}$

Incluirei ainda, mais adiante, um tritagonista, que em sua função terceira, contracenando com os dois primeiros, permita uma triangulação que seja mais reveladora do protagonismo primeiro e do deuteragonismo segundo, forjando uma terceiridade que torna mais favorável a compreensão e o pensamento. ${ }^{105}$

\footnotetext{
${ }^{104}$ Boal, 1991.

105 Ibidem. E também para uma análise da primeiridade, secundidade, terceiridade na formação do pensamento, ver Charles S. Peirce, (1995, p. 9): "Foi Kant, o rei do pensamento moderno, quem primeiro observou a existência, na lógica analítica, das distinções tricotômicas ou tripartidas. E realmente é assim; durante muito tempo tentei
} 
Sendo assim, podemos melhor dizer que o conceitoferramenta governamentalidade assume neste estudo um papel protagonista, e a tragicamentalidade um papel deuteragonista, por isto mesmo, não menos importante, mas segundo. E ao cuidado, caberá a função tritagonista, por último, mas não menos importante.

Trata-se da tentativa de sintetizar, neste neologismo, tragicamentalidade, duas ideias-força, que me parecem bastante úteis se aplicadas ao campo da produção do cuidado, em geral, e, mais ainda, quando aplicadas ao campo da produção do cuidado em saúde mental, em particular.

A primeira delas, como se deduz do que já foi escrito até aqui, é uma contraposição, ou, melhor dizendo, uma superposição, uma justaposição ao conceito revisto acima, de governamentalidade.

Apresento aqui, portanto, uma certa ousadia em tocar neste conceito, que, como já foi dito, é bastante complexo, nebuloso, incerto. E, tomo esta iniciativa, seguindo as próprias recomendações destes dois autores fundamentais para este trabalho, Nietzsche e Foucault:

\begin{abstract}
"Quanto a mim, os autores que gosto, eu os utilizo. O único sinal de reconhecimento que se pode ter para com um pensamento como o de Nietzsche, é precisamente utilizálo, deformá-lo, fazê-lo ranger, gritar. Que os comentaristas digam se se é ou não fiel, isto não tem o menor interesse." ${ }^{106}$
\end{abstract}

arduamente me convencer de que isso pertencia mais ao reino da imaginação, porém os fatos realmente não permitem este enfoque do fenômeno." E também, para uma mesma análise, ver Júlio Pinto (1995, p. 57-60).

${ }^{106}$ Foucault, 2001a, p. 143. 
Sendo assim, me dirijo ao conceito de governamentalidade, não simplesmente para conhecêlo, como algo definitivamente acabado, mumificado, que poderia ser, na melhor das hipóteses, venerado. Não, municiado por estes autores mesmos, me disponho a tomálo nas mãos, sacudi-lo, torcê-lo, fazê-lo gritar, extraindo seu suco se o tiver, e sentindo seu sabor amargo se puder.

Pois bem, nesse movimento, também quero seu avesso, escovando-o a contrapelo, como propõe Walter Benjamin, fazendo-o arrepiar.

É nesse seu desdobramento, ou rebatimento, que encontro aí, uma idéia do que seja um dos seus avessos. 0 que estaria afinal em sua dobra, pelo avesso?

Este é um conceito que funciona terrivelmente bem para revelar estes sistemas e mecanismos microfísicos ${ }^{107}$ que integram a dinâmica do biopoder (como explicitado acima). Mas, porém, nem tudo que está conectado nesta biomecânica funciona perfeitamente direcionado pela governamentalidade.

Há elementos, ou fatores, ou vetores de força, que mesmo que lhe pertençam, que estejam conectados nele, se encontram em seu avesso, e produzem, ou podem produzir, direcionamentos imprevistos, ou refluxos, resistência ${ }^{108}$, linhas de fuga. ${ }^{109}$

\footnotetext{
107 Refiro-me aqui à microfísica do poder: "O que Foucault chamou de microfísica do poder significa tanto um deslocamento do espaço de análise quanto do nível em que esta se efetua." Machado, 2001a, p. XII. ${ }^{108}$ Vide nota 103.

${ }^{109}$ Linhas de fuga no sentido que o confere Deleuze: "Acreditamos que as linhas são os elementos constitutivos das coisas e dos acontecimentos. Por isso cada coisa tem sua geografia, sua cartografia, seu diagrama. O que há de interessante, mesmo numa pessoa, são as linhas que a compõem, ou que ela compõe, que ela toma emprestado ou que ela cria. (...) Daí sua segunda observação: nós definimos a 'máquina de guerra' como um agenciamento linear que se constrói sobre linhas de fuga." Deleuze, 2007, p. 47.
} 
É assim, que estou ousando pensar esta parte integrante, mas que funciona ao avesso, simultaneamente, paradoxalmente, de forma ambivalente, e não dialética, nem necessariamente antagônica.

Mas para melhor pensar esta possibilidade é preciso nomeá-la, e, é aí que entra uma outra idéia, que trazia escondida em bolsos velhos de longa data, sem jamais me separar dela, mania de guardar coisas que parecem imprestáveis. Mas foi aí que emprestei uma à outra.

Trazia uma idéia do trágico, que encontrei em Nietzsche, um chiclete mágico que nunca perdia o sabor, por mais que eu o viesse ruminando e mastigando milhares de vezes. Certamente enfeitiçado nos poderosos caldeirões teóricos daquele bruxo imortal.

Esta era a idéia do trágico, da estética do trágico, que, como não desgrudava nunca de mim, já pretendia aplicála ao mundo do trabalho em saúde, dividindo-a com os outros, talvez na esperança de passá-la adiante.

Havia formado assim, o projeto "A Estética do Trágico na Produção do Cuidado". E sendo eu um operário da saúde mental, o projeto também poderia ser: "A Estética do Trágico na Produção do Cuidado em Saúde Mental".

Mas, aconteceu de eu me encontrar com este conceito de governamentalidade em Foucault, conceito escuro, forjado em noite de insônia sem lua. E ainda mais, de reencontrar o conceito de experiência trágica também em Foucault, e justamente, no choque das forças, que desde a Idade Clássica começaram a gestação dos desdobramentos que viriam a dar em governamentalidade.

Então achei onde grudar o trágico, e o colei às costas do outro, gerando tragicamentalidade, conseguindo ficar mais feia que sua irmã siamês, mais nebulosa e incerta 
ainda, como só as fêmeas conseguem ser.

Contudo, nesta incerteza, pude escapar do antigo título que, meio pomposo, meio enfadonho, lembrava os ricos de berço.

Apresento então esta Tragicamentalidade, que pode ser pensada de uma forma mais ampla, como no contexto próprio da Governamentalidade. Porém, o que almejo aqui, é tão somente conseguir sua aplicação aos cenários da produção do cuidado em saúde mental.

Ali, onde certamente atua, de forma inequívoca, a governamentalidade, como tão brilhante e exaustivamente demonstrado por Foucault. Que eu possa ter a destreza de fazer ver que, também ali, simultaneamente, poderá estar atuando a tragicamentalidade, no trabalho vivo em ato da produção do cuidado.

Passo então a esclarecer, mais detalhada e cuidadosamente, este trágico em Nietzsche, e de que estética se trata, para melhor me fazer entender. E começo do próprio encontro meu com este autor.

Seguia eu cego de tudo que ainda não vi. Ignorante de tudo que ainda não sei, e por não conseguir enxergar nem ao menos ao meu redor, por não compreender nem mesmo o que passa a minha volta, é que resolvi subir.

Como uma pulga que torceu sua patinha traseira, não conseguia sequer pular para ver o que passava um pouco mais a frente, e dediquei meus dias a escalar um galo de rica plumagem, que me parecia um gigante. Este, por sua vez, dizia ser mero anão cuja sombra assusta por estar em dorso de elefante.

É assim que resolvi escalar essa obra fabulosa de Nietzsche, para tentar, olhando por sobre as alturas de 
seus ombros, compondo surreal saltimbanco, enxergar um pouco mais do que se passa em meu cotidiano, nos novos serviços de saúde mental produzidos a partir da Reforma Psiquiátrica brasileira.

E nesta escalada encontrei uma extraordinária ideia do trágico, da trágica composição apolíneo-dionisíaca da vida em sua intensidade. Ideia por sinal inaugural e central na obra deste pensador, desde sua primeira publicação: “O Nascimento da Tragédia - Helenismo e Pessimismo".

Estamos em 1870, há um enfermeiro alemão nas trincheiras da Guerra Franco-Prussiana, integrante deste conjunto de exércitos germânicos liderados pela Prússia, conduzidos por Bismarck, rumo à fundação do II Reich, o segundo império alemão, pois a I Reich foi o Sacro Império Romano-Germânico fundado por Carlos Magno, o rei franco, e o III Reich foi a ambição nazista malograda.

Há um enfermeiro entre tantos outros que transportam e socorrem milhares de feridos estropiados, aleijados, moribundos, muitos deles condenados a morrer precocemente. $E$ este enfermeiro que nos interessa particularmente contrai a febre do tifo, fica gravemente adoecido, e será afastado dos campos de batalha. Mas é nestes campos que florescem suas ideias sobre a dimensão trágica da vida. É certo que já vinha pensando e produzindo bastante a este respeito, sobretudo sobre a tragédia em Sófocles, mas é na experiência febril da batalha e do tifo que se delineia melhor e mais, sua primeira obra: "O Nascimento da Tragédia - Helenismo e Pessimismo".

Ele próprio declara a este respeito:

“(...) ninguém sonharia que foi começado em meio aos estrondos da batalha de Wörth. Eu meditei sobre esses problemas diante dos muros de Metz, em frias noites de setembro, 
quando trabalhava na assistência aos feridos; seria antes de acreditar que ele fosse cinqüenta anos mais velho." ${ }^{110}$

Pois é esta ideia que floresceu no exercício da produção do cuidado, na condição de enfermeiro exercida por Nietzsche, que quero trazer de volta ao seu berço de origem, quero aplicar a ideia de uma estética do trágico à experiência, à vivência da produção do cuidado.

E como eu próprio dedico meus dias à produção do cuidado em saúde mental, no exercício da psiquiatria, em centros de atenção psicossocial e em outros serviços da rede pública, é a esta realidade que pretendo aplicar a idéia da estética do trágico. Portanto, trata-se aqui da estética do trágico na produção do cuidado em serviços públicos de saúde mental.

O fato é que, como se verá no transcorrer destas páginas, esta concepção trágica da vida encaixa-se de uma forma surpreendente com o trabalho cotidiano de produzir cuidado em saúde mental, funcionando como um conceitoferramenta operador, que permite uma leitura possível, funcionando como um potente analisador do que se vem operando no trabalho vivo em ato dos novos serviços substitutivos de saúde mental.

Mas, antes é preciso esclarecer algumas possíveis e plausíveis confusões que uma empreitada como esta que acabo de definir podem gerar. Sendo as primeiras delas os conceitos de estética, tragédia, o dionisíaco, o trágico em Nietzsche.

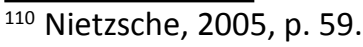


A Estética do Trágico:

A consideração de uma novidade estética, particularmente em referência aos Centros de Atenção Psicossocial, é freqüente na literatura sobre os mesmos, ainda que, de forma geral, os autores refiram-se a uma categoria mista ético-estética, sem maiores especificações, como nos três exemplos que tomo a seguir.

Para Amarante, o trabalho no CAPS é um processo permanente de invenção, gerando "competências em lidar com a loucura"111, construindo "novas formas de lidar, de escuta, de reprodução social dos sujeitos"112, acolhendo, cuidando, interagindo, inserindo, dentro de um "processo ético-estético", que envolve a produção de novos sujeitos de direito e novos direitos para os sujeitos.

Para Abílio da Costa-Rosa, o modo psicossocial de trabalhar em CAPS tem por objeto toda a existênciasofrimento dos sujeitos-cidadãos, causando uma "ampliação do conceito de tratamento e do conjunto de meios a ele dedicados"113, em um "verdadeiro exercício estético ${ }^{\prime 114}$, ou ético-estético, visando novas possibilidades de ser.

Estellita-Lins considera 0 processo terapêutico psicossocial uma experiência-acontecimento de criação estética, com o reconhecimento da legitimidade de modos de existir, mesmo que em singularidades extremas e trágicas. ${ }^{115}$

Como se pode ver, tais autores apontam uma novidade estética. Mas como pensar esta novidade estética

111 Amarante, 2003c.

112 Ibidem.

${ }^{113}$ Costa-Rosa, 2000.

114 Ibidem.

115 Estellita-Lins, 2000. 
em ação no CAPS? Será que simplesmente recordando da produção artística que acontece ali, em todas as oficinas de artes plásticas, teatro, dança, canto, etc; e da grande importância da criação artística nestes ambientes, inclusive como recursos terapêuticos?

Definitivamente não é disto que esses autores citados estão falando, mas sim tentam construir referência a algo bem mais amplo, que envolve todo o modo de produzir cuidado nestes serviços.

Creio que isto traz alguns problemas bem evidentes, sendo o primeiro deles o fato de que realizar uma oficina de teatro, ou do que seja, onde seja, com quem seja, não significa necessariamente nenhuma novidade estética, podendo muito bem ser uma absoluta repetição enfadonha.

Em segundo lugar, o fato de valorizar, ou de conferir "valor estético", no sentido trivial da expressão, ou de respeitar a produção artística daqueles considerados loucos, não representa nenhuma novidade. Afinal, não foi a Reforma Psiquiátrica que possibilitou o reconhecimento da obra de Van Gogh, Artaud, etc.

Em terceiro lugar, associar a estética meramente à produção artística é uma forma estreita de abordar a questão.

Retomo então a abordagem deste tema, partindo de alguma conceituação filosófica, certamente muito insuficiente e parcial, não me propondo aqui, de forma alguma, a pretensão de aprofundar filosoficamente 0 conceito de estética, que atravessa boa parte, senão toda a história da filosofia.

Retomo, para início de conversa, uma distinção bem importante, entre a estética 
"prática ou particular quando estuda as diferentes formas de arte"116, e a "Estética dita teórica ou geral, quando se propõe determinar qual a característica ou conjunto de características comuns que se encontram na percepção de todos os objetos que provocam a emoção estética." ${ }^{117}$

Esta emoção estética, por sua vez, seria:

“(...) um certo estado sui generis, análogo ao prazer, ao agrado, ao sentimento moral mas que não se confunde com nenhum deles e cuja análise é objeto da Estética enquanto ciência." 118

Uma primeira delimitação seria então a de que estou me referindo a esta segunda opção, à estética dita teórica ou geral, à que se refere ao mundo como plenamente sensível; e não à outra, que estuda as diferentes formas de arte.

Esta primeira delimitação seria a que envolve um:

“(...) deslumbramento ante a beleza e a Arte, que não é, senão, uma outra face do deslumbramento ante o mundo que já deve ter despertado, neles, o amor pela Filosofia." 119

Ora, a estética aqui vai ampliando seu leque e sua importância, envolvendo dimensões que vão muito além da arte estritamente dita, compondo o que seria o campo estético:

"A Estética é então, conforme vimos, essa espécie de reformulação da Filosofia inteira em relação à Beleza. Por isso, no

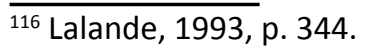

117 Ibidem, p. 343-344.

118 Ibidem, p. 344.

${ }^{119}$ Suassuna, 2007, p. 13. 
campo da Estética, estudamos, entre várias outras coisas, as relações entre a Arte, o conhecimento e a Natureza; a possibilidade de penetração filosófica do real; aproximamonos da essência da beleza, cujos fundamentos pressentimos, e assim por diante. É portanto, uma verdadeira visão do mundo em relação à beleza que temos de empreender, na Estética (...)."120

Temos aqui a beleza, já como um esforço conceitual de superação da relação da Estética com o Belo, já que este último se relaciona diretamente com a idéia de senso de medida, ordem, serenidade, harmonia, fruição tranqüila, equilíbrio. E a Estética, compondo uma visão de mundo, poderá incluir também a produção do horrível, do assustador, até do monstruoso, do terrificante. Poderá acolher assim, não apenas o prazer suave do Belo, mas também "o prazer do Trágico e do Sublime, misturados de sentimentos desagradáveis."121

A ruptura, portanto, com a exclusividade do Belo, com esse compromisso com a harmonia, dilatará o campo da Estética, ou o campo estético, possibilitando pensá-lo, posteriormente, como dimensão estética do existir:

\footnotetext{
"Registrando e oficializando o fracionamento do campo estético, e reservando o nome de Belo apenas para uma de suas categorias, os teóricos pós-kantianos trouxeram, desse modo, importante contribuição ao estudo da Estética. Foi graças a isso, por exemplo, que as Artes pré-clássicas, pós-clássicas e anticlássicas, mais dionisíacas do que apolíneas enfim, foram admitidas como legítimas no campo estético." ${ }^{122}$
}

120 Suassuna, 2007, p. 27.

${ }^{121}$ De Bruyne (apud SUASSUNA, 2007, p. 23).

122 Suassuna, 2007, p. 23-24. 
Já podemos ver então, na própria discussão a respeito do que seja a Estética ou o campo estético, o aparecimento do tema do dionisíaco, o tema do trágico, presente desde Aristóteles, mas de formas bem diferentes, ao longo da trajetória filosófica:

\begin{abstract}
“Desde Aristóteles há uma poética da tragédia; apenas desde Schelling, uma filosofia do Trágico. Sendo um ensinamento acerca da criação poética, o escrito de Aristóteles pretende determinar os elementos da arte trágica; seu objeto é a tragédia, não a idéia de tragédia." ${ }^{123}$
\end{abstract}

Vamos chegando, assim, à distinção entre uma filosofia estética que pensa a tragédia, e uma filosofia que pensa o trágico:

"Dessa poderosa zona de influência de Aristóteles, que não possui fronteiras nacionais ou temporais, sobressai como uma ilha a filosofia do trágico. Fundada por Schelling de maneira inteiramente não programática, ela atravessa o pensamento dos períodos idealista e pós-idealista, assumindo sempre uma nova forma." ${ }^{124}$

Será então com Schelling que se iniciará uma teoria do trágico, uma estética do trágico, que se refere não à produção das artes da tragédia, mas à condição humana trágica.

Neste sentido, proponho aqui um grande salto, me permitindo uma aproximação, guardadas as devidas proporções e pertinências; enfim, um salto que aproxima esta estética do trágico, da vida trágica humana, que vai surgindo com Schelling e encontrará ressonâncias no conceito de tragicidade e trágico "que domina a filosofia

$\overline{123}$ Szondi, 2004, p. 23.

${ }^{124}$ Ibidem, p. 24. 
posterior a 1800"125; enxergando aí algo aproximativo a uma estética da existência.

Refiro-me aqui, mais especificamente, à estética da existência em Michel Foucault.

Desta forma, espero construir, progressivamente, uma aproximação com o campo da produção do cuidado, pois, a estética da existência "marca em Foucault o retorno ao tema da invenção de si (fazer de sua vida uma obra de arte)"126, intimamente ligado ao cuidado de si, uma vez que "ocupar-se de si não é, portanto, uma simples preparação momentânea para a vida; é uma forma de vida."127

Com esta oferta de Foucault, estamos evidentemente neste campo amplificado do conceito de estética, contrapondo-a, inclusive, a uma moral, pois:

“(...) a ideia de uma moral como obediência a um código de regras está desaparecendo, já desapareceu. E a esta ausência de moral corresponde, deve corresponder uma busca que é aquela de uma estética da existência." ${ }^{128}$

E ao mesmo tempo, esta concepção aproxima a estética da política, da micropolítica, já que:

“(...) o sujeito se constitui através das práticas de sujeição ou, de maneira mais autônoma, através de práticas de liberação, de liberdade, como na Antigüidade - a partir, obviamente, de um certo número de regras, de estilos, de convenções que podemos encontrar no meio cultural." ${ }^{129}$

\footnotetext{
${ }^{125}$ Szondi, 2004, p. 24.

${ }^{126}$ Revel, 2005, p. 43.

${ }^{127}$ Foucault, 1997, p. 123.

${ }^{128}$ Foucault, 2004, p. 290.

129 Ibidem, p. 291.
} 
Com a estética da existência de Foucault abre-se uma leitura estética como validação das formas de existir, pelas técnicas de si, pois:

\begin{abstract}
“(...) trata-se de recolocar o imperativo do 'conhecer-se a si mesmo', que nos parece tão característico de nossa civilização, na interrogação mais ampla e que lhe serve de contexto mais ou menos explícito: que fazer de si mesmo? Que trabalho operar sobre si? Como 'se governar', exercendo ações onde se é o objetivo dessas ações, o domínio em que elas se aplicam, o instrumento ao qual podem recorrer e o sujeito que age?"130
\end{abstract}

Também em Nietzsche, observa-se uma perspectiva estética que declaradamente envolve a criação estética de si:

"A criação de si não supõe um modelo fixo de identidade, mas um conhecimento de si que se transforma continuamente. Dessa perspectiva, não há como traçar fronteiras bem delimitadas entre a arte e a vida; as duas esferas implicam a atividade de dar forma artisticamente, criar a si próprio, o que se pode denominar, em sentido amplo, uma 'invenção estética de si'.'

Isto tudo, me parece, vai promovendo uma aproximação, um deslocamento da estética em direção ao cuidado, às formas de produção do cuidado, sobretudo, às formas de produção do cuidado em saúde mental.

Neste mesmo sentido, mas de forma mais difusa, temos o "novo paradigma estético" proposto por Félix Guattari, que, na esteira da "produção maquínica de subjetividade" ${ }^{132}$, da concepção polifônica e transversalista e

\footnotetext{
${ }^{130}$ Foucault, 1997, p. 109-110.

${ }^{131}$ Nietzsche, 2009a, p. 31.

${ }^{132}$ Guattari, 1992, p. 15.
} 
heterogenética da subjetividade, valoriza o trans-subjetivo, "a criação, a invenção de novos Universos de referência"133, novos Territórios existenciais.

Guattari refere-se a um novo paradigma éticoestético, primeiramente em contraposição aos paradigmas cientificistas, de maneira que:

“(...) a questão não é mais saber se o inconsciente freudiano ou o inconsciente lacaniano fornecem uma resposta científica aos problemas da psique. Esses modelos só serão considerados a título de produção de subjetividade entre outros, inseparáveis dos dispositivos técnicos e institucionais que os promovem e de seu impacto sobre a psiquiatria, o ensino universitário, os mass mídia (......"134

Esta dimensão estética, ou de maneira equivalente ético-estética, está em Guattari vinculada á criatividade processual, ao criacionismo, insistindo para que:

“(...) fique bem claro que não assimilo a
psicose a uma obra de arte e o psicanalista,
a um artista! Afirmo apenas que os registros
existenciais aqui concernidos envolvem
uma dimensão de autonomia de ordem
estética." 135

Desta forma as máquinas de desejo, categoria primordial na obra deste autor, são convertidas nas "máquinas de criação estética"136, máquinas abstratas autopoiéticas engendrando "objetividades-subjetividades de um tempo que se instaura no cruzamento de componentes engajados em processos de heterogênese."137

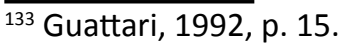

134 Ibidem, p. 21.

135 Ibidem. p. 24.

136 Ibidem. p. 67.

137 Ibidem. p. 71.
} 
Temos ainda neste autor uma profusão de estéticas, que desdobram-se em: perspectivas estéticas, práticas estéticas, desejo estético, potência estética, subjetividade estética, afetos estéticos, aspirações estéticas, componentes estéticos, pragmática ético-estética, dimensões estéticas.

Mas tudo isto sempre com:

“(...) implicações ético-políticas porque quem fala em criação, fala em responsabilidade da instância criadora em relação à coisa criada, em inflexão de estado de coisas, em bifurcação para além de esquemas pré-estabelecidos e aqui, mais uma vez, em consideração do destino da alteridade em suas modalidades extremas." ${ }^{138}$

Temos aqui uma estética ético-política fundada por "uma tensão para apreender a potencialidade criativa na raiz da finitude sensivel"139, com suas intensidades criadoras, ou melhor, seu "criacionismo mutante" ${ }^{140}$, suas constantes renovações de enquadramentos.

Também encontramos uma aproximação entre a estética e a política em Augusto Boal, que descreve possíveis poéticas-políticas, em particular aplicadas à realidade do fazer teatral, como por exemplo, "o sistema trágico coercitivo de Aristóteles" ${ }^{\prime 141}$, supostamente em ação nas fórmulas e concepções da tragédia clássica, em suas funções de purgação pela catarse, a partir da falha trágica, a harmatia, "única coisa que pode e deve ser destruída, para que a totalidade do ethos do personagem se conforme com a totalidade do ethos da sociedade."142

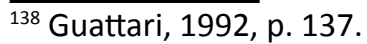

139 Ibidem, p. 142

140 Ibidem, p. 146.

${ }^{141}$ Boal, 1991, p. 15.

142 Ibidem, p. 49.
} 
Boal propõe, a partir de sua elaboração do conceito de catarse, que:

"Aristóteles constrói o primeiro sistema poderosíssimo poético-político de intimidação do espectador, de eliminação das "más" tendências ou tendências 'ilegais' do público espectador."143

Daí a necessidade do advento de novas estéticas, ou poéticas-políticas, que possam direcionar-se para a emancipação, através da transferência para o povo dos meios de produção teatral, em uma perspectiva evidentemente marxista.

Esta construção Aristotélica, à qual se refere Boal, estaria em sua "Arte Poética", texto que atravessou os tempos de forma bastante incompleta, fragmentada, e que formula a essência da tragédia como:

\begin{abstract}
“(...) a imitação de uma ação importante e completa, de certa extensão; num estilo tornado agradável pelo emprego separado de cada uma de suas formas, segundo as partes; ação apresentada, não com a ajuda de uma narrativa, mas por atores, e que, suscitando a compaixão e o terror, tem por efeito obter a purgação dessas emoções." ${ }^{144}$
\end{abstract}

É este ponto da purgação da compaixão e do terror que consiste na catarse, pela via privilegiada da ação, pois "os caracteres permitem qualificar o homem, mas é de sua ação que depende sua infelicidade ou felicidade."145

Uma perspectiva bastante ativista, que nos aproxima, no tema deste estudo em questão, de nosso agir em saúde.

E esta aproximação se dá, de forma cada vez mais ${ }_{143}$ Boal, 1991, p. 15.

${ }^{144}$ Aristóteles, 2007, p. 35.

${ }^{145}$ Ibidem, p. 36 
evidente, à medida que se desenrola o processo, relatado acima, da passagem de uma poética da tragédia, formulada por Aristóteles, ao nascimento, com Schelling, de uma filosofia do trágico:

"uma reflexão sobre o fenômeno trágico, sobre a ideia de trágico, sobre as determinações do trágico, sobre o sentido do fenômeno trágico, sobre a tragicidade."146

Segundo Machado, foi o filósofo Schiller o primeiro a elaborar uma teoria do trágico, na qual:

“(...) concebe o trágico, a partir do sublime, como um aspecto fundamental da existência humana e interpreta o gênero poético chamado tragédia como expressão dessa visão do homem, uma ideia moderna, estranha ao pensamento grego e a toda a história da humanidade até sua época." ${ }^{147}$

Schiller estabeleceu então, como condições necessárias para o trágico, uma representação viva do sofrimento, associada a "uma representação da resistência ao sofrimento, a fim de chamar à consciência a liberdade interior do ânimo"148, ou seja, a autonomia moral no sofrimento.

Entretanto, com suas reflexões, Schiller não chega a formular uma ontologia do trágico, restando em um ponto intermediário entre esta e a poética, daí caber a Schelling o nascimento de uma filosofia do trágico, formulada, pelo idealismo absoluto, seguido por "Hegel e o primeiro Hörderlin, e em seguida pelos próprios críticos do idealismo: o Hörderlin das "Observações" sobre Édipo e Antígona, Schopenhauer e Nietzsche." 149

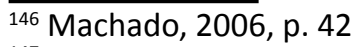

147 Ibidem, p. 72.

148 Ibidem, p. 72.

${ }^{149}$ Ibidem, p. 7.
} 
O percurso por estes autores é percorrido por Machado revelando a evolução desta construção ontológica do trágico, em direção a uma concepção de estética, neste contexto, que se aproxima surpreendentemente do campo da produção do cuidado, subsidiando uma possível reflexão sobre a dimensão estética do agir em saúde.

É assim que vai se delineando, em oposição a uma "poética da tragédia", esta nova "filosofia do trágico", entendendo a estética como a resposta humana à "questão da crueldade, procurando se proteger de um mundo sombrio, atroz, aterrador (...)."150

Neste sentido, contrapõem-se duas estéticas: uma que "desvia o olhar do que há de sombrio e tenebroso na vida cotidiana"151, negando estas dimensões do humano, uma estética unicamente apolínea, profundamente racionalista em sua pretensão de clareza, uma "estética socrática" nas palavras de Nietzsche ${ }^{152}$, propondo um caminhar progressivo na direção da consciência.

$E$, outra estética, que resgata as dimensões dionisíacas, em uma afirmação mais integral da vida, reconhecendo suas forças grotescas, cruéis, imprevisíveis, obscuras, uma estética do saber trágico.

Ora, é possível perceber facilmente a proximidade da estética apolínea ao tratamento moral da psiquiatria, sobretudo se analisarmos a concepção do efeito catártico para tal estética, que preconiza "um melhoramento moral do indivíduo"153, lembrando que o próprio termo catarse tem suas origens médicas de efeito terapêutico purificador, e que em tal estética:

\footnotetext{
${ }^{150}$ Machado, 2006, p. 203.

151 Ibidem, p. 205.

152 Nietzsche, 2006.

${ }^{153}$ Chaves, 2006.
} 
“(...) um poderoso processo de esclarecimento quer mudar o mundo de acordo com o pensamento; tudo o que existe sucumbe a uma crítica devastadora porque o pensamento ainda se desenvolve unilateralmente."154

Ao contrário, pensando balizar o agir em saúde mental por uma estética do trágico, teremos não mais "Édipo Rei", mas "Prometeu" como tragédia fundamental155, longe da "justiça poética"156, da poética dos tribunais, onde se possa ouvir o pathos e não apenas ver a ação, em "um grande acontecimento em suas conseqüências patéticolíricas"157, no qual "o artista nasceu, o homem com órgãos transfigurados."158

Não posso deixar de fazer uma aproximação entre este homem Nietzschiano com órgãos transfigurados, e o que Artaud denominou de Corpo Sem Órgãos.

Onde Nietzsche buscava resgatar a ligação permanente entre conhecimento e vida, Artaud buscará a ligação permanente entre arte e vida. Isto significa aprender também com Artaud, esta estética do trágico, que, podemos entender assim, era ao que ele se referia em seu chamado "teatro da crueldade".

Esta estética do trágico conhece, em Nietzsche, seu apogeu. Constituindo um tema fundamental e recorrente para este autor. Tema presente não só nas obras que se ocupam diretamente do trágico, compostas por "Introdução à Tragédia de Sófocles", e "O Nascimento da Tragédia ou Helenismo e Pessimismo"; mas de uma forma difusa, ao longo de toda sua produção.

\footnotetext{
$\overline{{ }^{154} \text { Nietzsche, } 2006 .}$.

${ }^{155}$ Chaves, 2006.

${ }^{156}$ Nietzsche, 2006.

${ }^{157}$ Ibidem.

${ }^{158}$ Ibidem.
} 
O projeto exposto por Nietzsche no "Nascimento da Tragédia" é, primeiramente, radicalmente estético, na medida em que "a existência do mundo só se justifica como fenômeno estético."159

Mas também poderia ser dito, com discreta modificação desta fórmula, que: "a existência e o mundo aparecem justificados somente como fenômeno estético."160

E esta estética, como justificação do mundo e da existência, se contrapõe à doutrina cristã, enquanto:

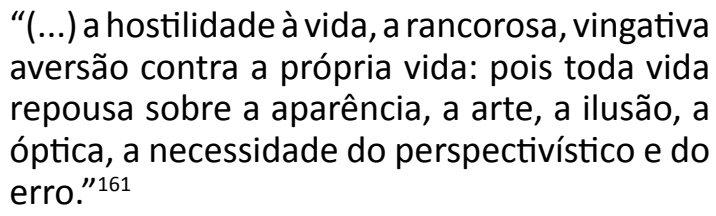

Uma exegese e justificação puramente estética do mundo, em contraponto ao "ódio ao 'mundo', a maldição dos afetos, o medo à beleza e à sensualidade "162; contraponto ao anseio pelo nada, pelo repouso constitutivos do cristianismo.

Essa justificação estética se estende inclusive ao "pior dos mundos", por ser este, juntamente com o melhor dos mundos, o humano:

"Se pudéssemos imaginar uma encarnação da dissonância - e que outra coisa é o homem? - tal dissonância precisaria, a fim de poder viver, de uma ilusão magnífica que cobrisse com um véu de beleza a sua própria essência." ${ }^{163}$

\footnotetext{
${ }^{159}$ Nietzsche, 2005, p. 18.

160 Ibidem. p. 141.

$161 \mathrm{Ibidem}$. p. 19.

162 Ibidem. p. 19.

${ }^{163}$ Ibidem. p. 143.
} 
Estética que resgata a dignidade de toda vida, em movimentos que "tornam de algum modo a existência digna de ser vivida e impelem ao momento seguinte."164

O trágico em Nietzsche faz, desta forma, coro ao seu projeto por uma transvaloração de todos os valores, por uma retomada da vida em sua plenitude, não mais apartada de si, reduzida pelo ressentimento, pelo remorso, constrangida por uma moral de escravos.

Nietzsche leva a dimensão estética às últimas conseqüências, considerando que cada ser humano é um artista consumado, sendo pelas "artes, mercê das quais a vida se torna possível e digna de ser vivida." ${ }^{165} \mathrm{Ou}$, ainda além, "o homem não é mais artista, tornou-se obra de arte: a força artística de toda a natureza, para a deliciosa satisfação do uno-primordial (...)."166

O trágico estará em sintonia com seu grande Sim à vida, com a superação do homem em direção a um além homem, da vida conectada consigo mesma, em uma "fantástica exaltação da vida." ${ }^{167}$

Trágico que denuncia incessantemente o projeto de um exclusivismo apolíneo, e que traz o reencontro de Apolo e Dionísio:

"E vede! Apolo não podia viver sem Dionísio! $O$ 'titânico' eo 'bárbaro' eram, no fim das contas, precisamente uma necessidade tal como o apolíneo!"168

Reencontro que se dá necessariamente pelo retorno do dionisíaco, banido no ocidente pelo socratismo:

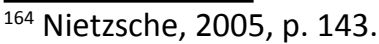

165 Ibidem, p. 29.

166 Ibidem, p. 31.

167 Ibidem, p. 36.

168 Ibidem, p. 41.
} 
"O indivíduo, com todos os seus limites e medidas, afundava aqui no autoesquecimento do estado dionisíaco e esquecia os preceitos apolíneos. $O$ desmedido revelava-se como a verdade, a contradição, o deleite nascido das dores, falava por si desde o coração da natureza." 169

O trágico, neste sentido, como crítica ao socratismo, representa todo um enfrentamento de uma longa tradição filosófica ocidental:

"Agora, junto a esse conhecimento isolado ergue-se por certo, com excesso de honradez, se não de petulância, uma profunda representação ilusória, que veio ao mundo pela primeira vez na pessoa de Sócrates aquela inabalável fé de que o pensar, pelo fio condutor da causalidade, atinge até os abismos mais profundos do ser e que o pensar está em condições, não só de conhecê-lo, mas inclusive de corrigi-lo." 170

E neste enfrentamento, pelo trágico, do "socratismo estético"171, da "roda motriz do socratismo lógico"172, do "único olho ciclópico de Sócrates"173 no qual "nunca ardeu o gracioso delírio de entusiasmo artístico"174; encontramos o enfrentamento da própria ciência, como critério de verdade:

"Quem se der conta com clareza de como depois de Sócrates, o mistagogo da ciência, uma escola de filósofos sucede a outra, qual onda após onda, de como a universalidade jamais pressentida da avidez de saber, no mais remoto âmbito do mundo

\footnotetext{
${ }_{169}$ Nietzsche, 2005, p. 41.

170 Ibidem, p. 93.

${ }^{171} \mathrm{Ibidem}$, p. 81.

${ }^{172}$ Ibidem, p. 86.

${ }^{173}$ Ibidem, p. 87.

${ }^{174}$ Ibidem, p. 87.
} 
civilizado, e enquanto efetivo dever para com todo homem altamente capacitado, conduziu a ciência ao alto-mar, de onde nunca mais, desde então, ela pôde ser inteiramente afugentada, de como através dessa universalidade uma rede conjunta de pensamentos é estendida pela primeira vez sobre o conjunto do globo terráqueo, com vistas mesmo ao estabelecimento de leis para todo um sistema solar; quem tiver tudo isso presente, junto com a assombrosamente alta pirâmide do saber hodierno, não poderá deixar de enxergar em Sócrates um ponto de inflexão e um vértice da assim chamada história universal."175

O trágico em Nietzsche condensa, portanto, seu enfrentamento do cristianismo, da compaixão, de toda a tradição filosófica do socratismo, do racionalismo, do iluminismo, do positivismo, e de seu mais ilustre opositor, a ciência:

"Quero falar apenas da oposição mais ilustre à consideração trágica do mundo, e com isso me refiro à ciência, otimista em sua essência mais profunda, com seu progenitor Sócrates à testa." ${ }^{176}$

Trágico que participa também de seu enfrentamento pela superação do próprio homem, entendido como ponte e não ponto de chegada, em direção ao "super-homem."177

Trágico como representante maior, como estética do amor fati, esse absoluto Sim à vida:

“(...) quero cada vez mais aprender a ver como belo aquilo que é necessário nas coisas: - assim me tornarei um daqueles que fazem belas as coisas. Amor fati [amor ao destino]:

$\overline{175}$ Nietzsche, 2005, p. 94.

${ }^{176}$ Ibidem, p. 97.

${ }^{177}$ Nietzsche, 2007, p. 236. 
seja este, doravante, o meu amor! Não quero fazer guerra ao que é feio. Não quero acusar, não quero nem mesmo acusar os acusadores. Que a minha única negação seja desviar o olhar! E, tudo somado e em suma: quero ser, algum dia, apenas alguém que diz Sim!"178

Trágico que se afigura também como desconstrução deste pressuposto tão caro a essa tradição, à qual Nietzsche pretende se opor: o indivíduo. Desconstrução que deve brotar da "alegria pelo aniquilamento do indivíduo."179

Aniquilamento necessário para dar passagem a uma multiplicidade que nos habita, amordaçada pelo preposto do indivíduo:

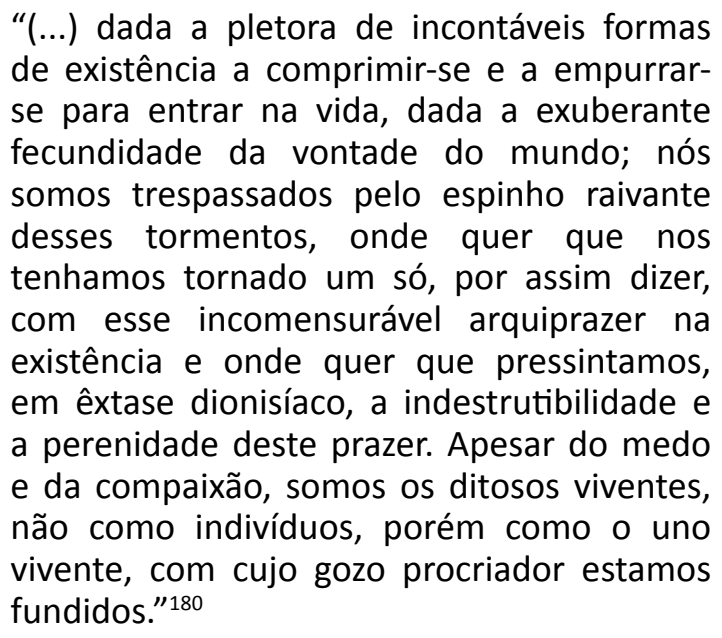

Trágico que permite uma nova visibilidade, desde a inclusão da dimensão dionisíaca, quando:

“(...) tudo o que chamamos agora de cultura, educação, civilização terá algum dia de comparecer perante o infalível juiz

$\overline{{ }^{178} \text { Nietzsche, } 2009}$, p. 187-188.

179 Nietzsche, 2005, p. 105.

180 Ibidem, p. 102-103. 


\section{Dionísio." $^{181}$}

Claro, que acrescentaríamos a esta lista de cultura, educação e civilização; também a saúde, como tendo de comparecer a este juízo.

Juízo que aponta para a "sabedoria dionisíaca"182, como transbordamento do império do equilíbrio calculista:

"A tragédia está sentada em meio a esse transbordamento de vida, sofrimento e prazer; em êxtase sublime, ela escuta um cantar distante e melancólico - é um cantar que fala das Mães do Ser, cujos nomes são: Ilusão, Vontade, Dor." ${ }^{183}$

O trágico em Nietzsche ganha o estatuto de uma fabulosa convocação à vida:

"O tempo do homem socrático passou: coroai-vos de hera, tomai o tirso na mão e não vos admireis se tigres e panteras se deitarem, acariciantes, a vossos pés. Agora ousai ser homens trágicos: pois sereis redimidos." 184

Desta forma, o trágico apresenta uma verdadeira luta contra o império apolíneo socrático que:

"Com a força descomunal da imagem, do conceito, do ensinamento ético, da excitação simpática, o apolíneo arrasta o homem para fora de sua auto-aniquilação orgiástica e o engana, passando por sobre a universalidade da ocorrência dionisíaca, a fim de levá-lo à ilusão de que ele vê uma única imagem do mundo (...)."185

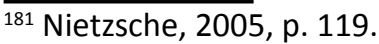

182 Ibidem, p. 119.

183 Ibidem, p. 123.

184 Ibidem, p. 123.

185 Ibidem, p. 127.
} 
Trágico como estética que não só justifica a vida, mas salva através da arte, a própria vida.

Como exemplo deste trágico, Nietzsche resgatará Prometeu em substituição a Édipo:

"À glória da passividade contraponho agora a glória da atividade, que o Prometeu de Ésquilo ilumina." ${ }^{186}$

Este trágico contrapõe-se a um:

"Socratismo estético, cuja suprema lei soa mais ou menos assim: 'Tudo deve ser inteligível para ser belo', como sentença paralela à sentença socrática: 'Só o sabedor é virtuoso'."

Nietzsche insistirá neste trágico que pressupõe a conexão entre o apolíneo e o dionisíaco, e não a exclusão total de um ou de outro; gerando um estado de necessária tensão impulsionadora, logo, uma difícil coalisão entre tensão e integração, que faz lembrar o conceito de tensigridade, oriundo da engenharia estrutural e desenvolvido por Carlos Castañeda ${ }^{187}$, para falar deste jogo de tensão e integridade.

Em sua crítica aos limites da visão exclusivista apolínea, Nietzsche aponta em primeiro lugar a "impossibilidade de o apolíneo se apresentar como alternativa à racionalidade." $188 \mathrm{E}$, em segundo lugar:

“(...) o fato de ela não ser uma afirmação
integral da vida. Como uma proteção contra
o terrível da dor, do sofrimento, da morte,
que funciona como encobrimento, o saber
apolíneo evidencia-se parcial, ao deixar
de lado algo que não pode ser ignorado e

$\overline{186}$ Nietzsche, 2005, p. 65.

${ }^{187}$ Autor de "A Erva do Diabo", "viagem a Ixtlan", entre outros.

${ }^{188}$ Machado, 2006, p. 210. 
fatalmente se impõe: a outra força artística da natureza, o dionisíaco." ${ }^{189}$

Ora, me parece que, não é preciso grande esforço para enxergar, a partir desta discussão, uma estética trágica, apolíneo-dionisíaca em defesa da vida, em respeito às multiplicidades da vida, aos "inumeráveis estados do ser", relembrando tal expressão de Antonin Artaud. ${ }^{190}$

A conexão com o mundo da produção do cuidado parece saltar aos olhos.

Nesta estética apolíneo-dionisíaca em defesa da vida, o homem:

“(...) sente-se, assim como Prometeu libertado, livre de todas as amarras da individualidade, movido por uma liberdade poderosa e ilimitada, transportado pela tempestade de uma alegria e de uma dor nunca antes experimentada." 191

Uma aposta que guarda semelhanças inegáveis com certo cuidado em saúde mental, que aposta na multiplicidade das subjetivações, já que:

“(...) em vez da consciência de si apolínea, o culto dionisíaco produz uma desintegração do eu, uma abolição da subjetividade até o total esquecimento de si: um desprendimento de si próprio (...)." ${ }^{192}$

Tal estética apolíneo-dionisíaca do trágico traria então a potência necessária para fazer barrar:

189 Machado, 2006, p. 211.

${ }^{190}$ Artaud busca uma aproximação entre arte e vida, em obras como "O Teatro e seu Duplo", entre outras; assim como Nietzsche busca essa aproximação entre conhecimento e vida.

${ }^{191}$ Machado, 2006, p. 213.

192 Ibidem, p. 214. 
“(...) a negação do querer, esse estado em que o desejo se cala, em que a vontade cessa de ter motivos, é o remédio ou, mais precisamente, o calmante - pois, como diz Philonenko, se não é possível curar uma doença metafísica, pode-se ao menos the receitar um calmante (...)."193

A metáfora psiquiátrica é aqui tão reveladora de uma opção estética, ainda hegemônica na disputa da produção do cuidado em saúde mental, que chega a assustar.

É desta composição trágica, desta estética apolíneodionisíaca, que posso pensar em tragicamentalidade, acopladamente à governamentalidade, e seu uso operatório gerador de visibilidades sobre o agir em saúde.

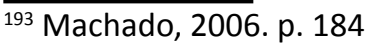





\section{IV - O Metódico}

Um método deve ser feito para nos livrarmos dele. Foucault, aula de 08 de fevereiro de 1978

O circunspecto, o comedido amanuense Belmiro, esse retrato fiel do eterno funcionário público, desenhado por Cyro dos Anjos, avisa:

"Bem agem aqueles que acorrentam os homens e lhes dão um duro trabalho. Deixemno folgado, e teremos o anarquista, o poeta, o céptico e outros seres que perturbam a vida do rebanho." ${ }^{\prime 194}$

A pena mordaz de Cyro dos Anjos vai desenhando este escrevente exemplar em sua vidinha, e suas exasperações e aflições diante da paixão ridícula que lhe assalta os afetos, em geral tão comezinhos.

O metódico funcionário fica interessante ali quando seu método não funciona. Daí seu vaticínio: acorrentem os homens antes que sobrevenham os seres que perturbam $o$ rebanho. Ora, temos no método uma das boas formas de acorrentar os homens, principalmente aqueles, talvez mais perigosos, que se arvoram a embrenhar pelos caminhos

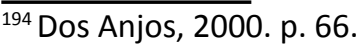


da produção dos saberes, correndo o grave risco de serem criativos, eaté de produzirem algo mais que um domesticado metódico conhecimento científico funcionário da repartição de alguma disciplina bem estabelecida e ordenada em uma hierarquizada instituição pública de saberes.

Mas e quando estamos procurando algo que possa perturbar a vida do rebanho?

Aí então temos que fazer desta procura um método que não seja metódico, que não gere um conhecimento anódino, mas pelo contrário que faça contrair os pêlos.

Um método tão peculiar que não seja para acorrentar os homens e lhes dar um duro trabalho, mas sim afirmar a alegria de conhecer e o prazer de descobrir, sem necessidade de transformar o trabalho naquele traço obsessivo descrito por Henry Ey:

“(...) um outro fato que deve ser considerado sempre foi observado pelos clínicos: é a mania de ordem e a meticulosidade. São indivíduos que têm uma necessidade irresistível de regulamentar tudo, de contar tudo e de se submeter aos imperativos ou às proibições rigorosas; são estritos e avaros."195

Um método menos restrito e menos avaro, que possa ser exigente e competente pela busca do saber, mas sem o "rigor mortis" dos métodos rigorosos. É este o desafio, com o risco de desafinar no coro das vozes da ciência, mas podendo fazer falar uma autêntica produção de saber implicado, interessado e interessante, em lugar do frio e distante desinteressado conhecimento.

Para começar é preciso então situar um lugar onde possam acontecer estas estranhas engenhocas metodológicas.

$\overline{195}$ Ey, 1981, p. 496. 
O Incrível Circo de Pulgas Amestradas de Monsieur Merhy:

Contam os lendários, que os fantásticos circos de pulgas atingiram o auge de sua popularidade percorrendo a Europa dos séculos XVIII e XIX, época em que haviam circos com até trezentos "insetos artistas", e que muitos deles fugiam, levando seus donos a espalharem cartazes oferecendo fortunas a quem indicasse o paradeiro de seu elenco.

Dentre as centenas de espécies de pulgas existentes, as preferidas eram as que atacam o homem, a Pulex irritans, e o treinador passava uns três meses adestrando as pulgas, que vivem em média dois anos, daí que a carreira artística dos micro-atores era bem curta, exigindo uma rotatividade do estrelato quase tão intensa quanto a do mundo dos humanos.

De toda forma, as pessoas ficavam cativadas pelo singelo espetáculo dos insetos andando na corda bamba, puxando engenhocas centenas de vezes seu próprio peso, levantando volumes dezenas de vezes maiores que seu próprio tamanho, saltando por obstáculos, sendo arremessados por um canhãozinho, mas principalmente, o que fascinava o público, era a ideia de que seres tão desprezíveis e pequenos pudessem ser treinados e amestrados.

Mas não demorou muito até que os cientistas viessem desencantar o espetáculo, explicando que as pulgas não são capazes de aprender como um cachorro, que seu sistema nervoso é muito pouco desenvolvido, que não existe adestramento de pulgas, e o que ocorre é, simplesmente, o aproveitamento dos reflexos próprios do inseto, suas reações naturais quando por exemplo colocados na corda bamba, ou atraídos pelo gás carbônico soprado pelo domador de pulgas. 


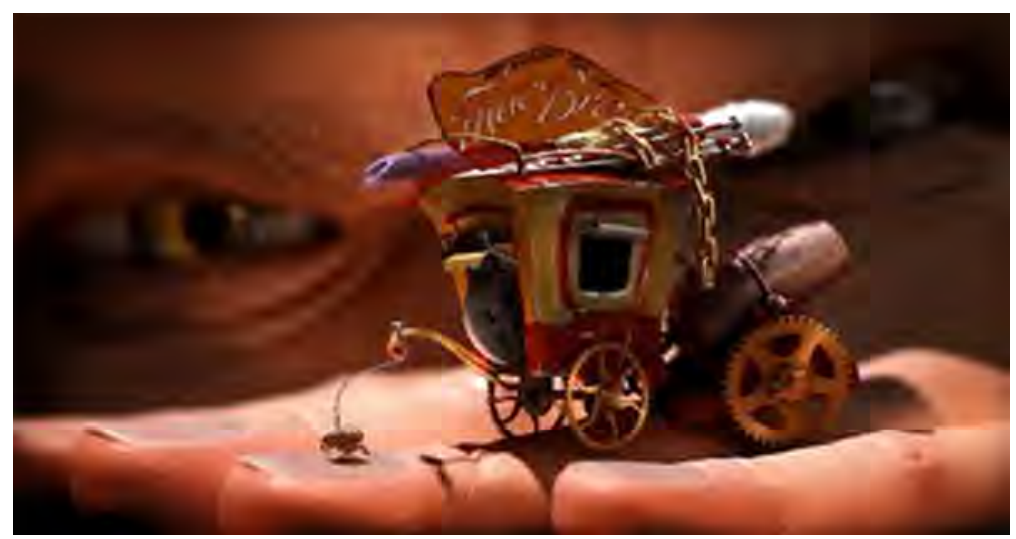

Fonte: Autor desconhecido. Disponível em: <http://www.mdig.com. br/?itemid=4435>. Acesso em: 06 out 2014.

Há também quem diga que os pequenos espetáculos apreciados por lupa entraram em decadência quando o higienismo varreu das cidades da Europa a imensa população de pulgas que servia de celeiro para os caçadores de micro-talentos.

Quero, entrementes tantas histórias curiosas que envolvem este capítulo tão peculiar das artes cênicas, aproveitá-lo como modelo explicativo de um certo modo metodológico operante no funcionamento do coletivo Micropolítica do Trabalho e o Cuidado em Saúde, do qual esta presente investigação é tributária.

Trata-se, portanto, do funcionamento do grupo de pesquisas e investigações sob o tema do trabalho em saúde, em um sistema que pode ser considerado circo de pulgas amestradas. Mas como é isto? Ou melhor, perguntando com Guattari, como é que isto funciona?

Consideremos aqui, para completar este paralelo, uma das versões das inúmeras tradições circenses, que descreve o dono do circo, o chamado monsieur, o senhor do circo, de um circo qualquer e não especificamente de um circo de 
pulgas. Pois bem, foi sempre envolto em muitas histórias fabulosas que circulavam esse singular personagem, e, sobretudo, suas qualidades sobrenaturais, pois monsieur era quem recrutava toda a trupe, era quem recebia a cada um, devendo reconhecer os talentos manifestos e ocultos de cada participante para um espetáculo de maior variedade e grande entusiasmo.

Portanto, monsieur trabalhava assim, cooperando talentos, apostando na diversidade, na pluralidade, formando muitas vezes um rico espetáculo integrado por várias raças, variadas etnias, absorvendo talentos ao longo de uma trajetória tradicionalmente nômade, mambembe, em uma busca não de sempre mais do mesmo, mas, ao contrário, uma procura pelo que ainda não há, um eterno devir ciganeando pelas paragens.

Acrescente-se ainda que monsieur, sendo dono de circo perambulante, sempre e por toda parte era abordado por interessados em seguir viagem com o circo, em muitos casos isto podia significar até fugir com o circo, sendo o circo então uma outra vida possível que vagava atravessando os cotidianos engessados, portando uma mítica carga de devir artístico em suas carroças.

$E$, em muitos casos, os pretendentes ao circo não eram artistas propriamente ditos, mas pessoas em geral, apenas dispostas ao sonho, sendo particularmente nestes casos que as enigmáticas qualidades de monsieur deviam se manifestar, pois era então sua misteriosa função "adivinhar" os talentos dos pretendentes. Claro que essa clarividência poderia estar baseada em sua experiência, em seu faro comercial, em seu tino empresarial, em inúmeras tentativas e erros, em treinamentos, ou até em hierarquias e servilismo, mas o efeito final podia ser a extração de um novo e insuspeitado talento, capacidade, aptidão que fosse 
extraordinária para a própria pessoa que agora o exercia.

Há quem diga que especialmente difícil era a descoberta dos verdadeiros palhaços. Isto porque a imagem do circo está tão intimamente ligada a este personagem, que até se confunde com ele, sendo mesmo o segredo e o tempero de cada circo. Daí o especial empenho de monsieur na descoberta de seus palhaços, já que ser palhaço é bem mais que fazer palhaçada.

Pode até parecer fácil e divertido, já que aprender algumas piadas, alguns truques, algumas brincadeiras, repetir alguns números, parece bem mais acessível que domar leões ou elefantes, ou arriscar-se no trapézio. Contudo, a busca por um verdadeiro palhaço incluía a procura de alguém que pudesse apostar aí todo seu jeito de ser gente, principalmente seu mais autêntico ridículo, colocando assim na corda bamba não só seu corpo, mas toda uma peculiar forma de existência, com suas dificuldades e fragilidades.

Estas sendo a matéria prima primordial do difícil picadeiro do palhaço, sua fragilidade, suas dificuldades, seu ser incongruente com o mundo vindo à tona e permitindo o risível, este desabafo necessário de toda uma platéia de colegas de infortúnio, que podem compartilhar secretamente incongruências que tais.

Dizendo de outro modo, o palhaço se utiliza de seus incômodos como ferramentas de trabalho, e quanto maior o incômodo tanto mais poderosas serão suas ferramentas e mais proveitosa sua produção.

É deste ponto que quero retornar ao coletivo Micropolítica do trabalho e o cuidado em saúde, donde foi gestado este estudo.

É que também ali, sob o desafio permanente da 
produção de saberes e investigações, faz-se a aposta de que seja a partir dos mais autênticos incômodos, presentes no mundo do trabalho em saúde, que se pode produzir saberes para aumentar a potência de produção de cuidado nestes ou noutros cenários.

Sendo assim, é preciso colocar na mesa as pulgas que trazemos atrás das orelhas, pois elas serão importantes ferramentas de trabalho, ou, afinal, elas é que nos farão trabalhar. Serão aquelas maiores e mais incômodas pulgas que exigirão de mim respostas que realmente preciso construir.

Mas quem pudesse assistir assim àquele picadeiro onde as pulgas são colocadas a trabalhar em malabarismos inimagináveis, poderia facilmente pensar que só podem ser pulgas amestradas e domesticadas. Mas reside aí a mesma ilusão de todos os circos de pulgas, pois, o que opera é simplesmente deixar com que as pulgas realizem seus reflexos naturais, apenas direcionando-os para certa produção.

No caso específico deste circo de pulgas, a contribuição primordial destas é fazer dançar seus portadores, é fazer com que se mexam, com que não se acomodem, com que mudem de lugar, se possível até desterritorializar, já que as pulgas não negociam, elas querem nada menos que nosso sangue servido à mesa.

É este difícil banquete que tem sido comandado por monsieur Merhy, em seu incrível perambulante circo de pulgas.

Banquete semelhante àquele outro descrito por Platão ${ }^{196}$, no qual a rodada de homenagens ao deus Eros vai girando e se encaminhando em direção a esta peculiar

196 Platão, 1999. 
paixão pelo saber, ao mesmo tempo em que os convivas louvando a Eros vão falando de si próprios e de seu pathos, do que a cada um move e toca, neste encontro em que estão o médico Erixímaco, o político Alcibíades, artistas como Agáton, poetas como Aristófanes, filósofos como Sócrates, em uma franca degustação que deixa a "contemporânea" ideia de transdisciplinaridade ruborizada.

Uma tal ideia de interdisciplinaridade, multidisciplinaridade ou mesmo de transdisciplinaridade não consegue de fato refletir suficientemente o funcionamento deste circo das pulgas hematófagas de monsieur Merhy. O que acontece ali não pode ser chamado de grupo transdisciplinar, mas talvez de coletivo indisciplinar, já que se trata justamente de colocar na mesa algumas disciplinas e suas teorias, mas para devorá-las de uma forma antropofágica, muitas vezes desconstruindo suas lógicas de funcionamento e não simplesmente multiplicando disciplinas. Temos aqui então um circo de pulgas hematófagas e antropofágicas.

Mas para além desta hemato e antropofagia, tratase substancialmente de um espaço criativo, gerativo, gestacional de saberes, no sentido mesmo a que se refere Sócrates no diálogo "Teeteto" de Platão:

"Sócrates - São dores de parto, meu caro Teeteto. Não estás vazio; algo em tua alma deseja vir à luz.

Teeteto - Isso não sei, Sócrates; só disse o que sinto.

Sócrates - E nunca ouviste falar, meu gracejador, que eu sou filho de uma parteira famosa e imponente, Fanerete?

Teeteto - Sim, já ouvi.

Sócrates - Então, já te contaram também 
que eu exerço essa mesma arte?

Teeteto - Isso, nunca.

Sócrates - Pois fica sabendo que é verdade; porém não me traias; ninguém sabe que eu conheço semelhante arte, e por não o saberem, em suas referências à minha pessoa não aludem a esse ponto; dizem apenas que eu sou o homem mais esquisito do mundo e que lanço confusão no espírito dos outros. A esse respeito já ouviste dizerem alguma coisa?

Teeteto - Ouvi.

Sócrates - Queres que te aponte a razão disso?

Teeteto - Por que não?

Sócrates - Basta refletires no que se passa com as parteiras, para apanhares facilmente $o$ que desejo assinalar. Como muito bem sabes, não servem para exercer o ofício de parteira as mulheres que ainda concebem e dão à luz, mas apenas as que se tornaram incapazes de procriar.

Teeteto - Perfeitamente.

Sócrates - Dizem que a causadora disso é Ártemis: por nunca haver dado à luz, recebeu a missão de presidir aos partos. As estéreis de todo, ela não concede a faculdade de partejar, por ser fraca em demasia a natureza humana para adquirir uma arte de que não tenha experiência. As que já passaram de idade foi que ela concedeu esse dom, para honrar nelas sua imagem.

Teeteto - Compreende-se.

Sócrates - E não é também compreensível e 
até mesmo necessário, que as parteiras

conheçam melhor do que as outras quando uma mulher está grávida?

Teeteto - Perfeitamente.

Sócrates - Sim, por meio de drogas e encantamentos, elas conseguem aumentar as dores ou acalmá-las, como queiram, levar a bom termo partos difíceis ou expulsar o produto da concepção quando ainda não se acha muito desenvolvido.

Teeteto - Isso mesmo.

Sócrates - E não observastes, outrossim, que são casamenteiras muito hábeis, por

conhecerem a fundo qual é a mulher mais indicada para este ou aquele varão, porque possam ter filhos perfeitos?

Teeteto - Disso nunca ouvi falar.

Sócrates - Pois fica sabendo que elas se envaidecem mais desse conhecimento do que de saber cortar o cordão. Basta refletires. És de parecer que compete à mesma arte cultivar e colher os frutos e também conhecer que planta ou semente irá melhor neste ou naquele terreno? Ou será diferente?

Teeteto - Não; é a mesma.

Sócrates - E para a mulher amigo, és de opinião que uma arte ensinará isso, e outra a colher os frutos?

Teeteto - É pouco provável.

Sócrates - Não; o certo seria dizer: nada provável. Mas por causa do comércio 
desonesto e sem arte de acasalar varão com mulher, denominado lenocínio, abstêm-se da atividade de casamenteiras as parteiras sensatas, de medo de no exercício de sua arte incorrerem na suspeita de exercerem aquelas práticas. Nada obstante, só às verdadeiras parteiras é que compete promover as uniões acertadas.

Teeteto - Parece.

Sócrates - Eis aí a função das parteiras; muito inferior à minha, Em verdade, não acontece às mulheres parirem algumas vezes falsos filhos e outras vezes verdadeiros, de difícil distinção. Se fosse o caso, o mais importante e belo trabalho das parteiras consistiria em decidir entre o verdadeiro e o falso, não te parece?

Teeteto - Sem dúvida.

Sócrates - A minha arte obstétrica tem atribuições iguais às das parteiras, com a

diferença de eu não partejar mulher, porém homens, e de acompanhar as almas, não os corpos, em seu trabalho de parto. Porém a grande superioridade da minha arte consiste na faculdade de conhecer de pronto se o que a alma dos jovens está na iminência de conceber é alguma quimera e falsidade ou fruto legítimo e verdadeiro." 197

Foi, portanto, neste incrível circo de pulgas hemato-antropofágicas que pari como tema específico de investigação ou também como objeto de pesquisa, a estética do trágico, a tragicamentalidade na produção do cuidado em saúde mental, que já trazia em mim, em longa gestação paquiderme de vários anos.

Mas ressalvo que me refiro a objeto de pesquisa, em ${ }^{197}$ Platão. 
uma particular concepção, explicitada por Michel Foucault, quando descreve um pouco de sua análise genealógica em relação à governamentalidade, esta noção que ele mesmo reconhece como problemática, artificial, obscura, fraca, difusa e lacunar, mas capaz de um tríplice deslocamento em direção à exterioridade.

Primeiro, buscando escapar do "institucionalcentrismo", para as tecnologias de poder, ou seja, "passar por fora da instituição para substituí-la pelo ponto de vista global da tecnologia de poder."198

Segundo, substituindo o ponto de vista funcional pelo das estratégias e táticas numa economia geral de poder.

Terceiro, sendo, finalmente, o ponto que nos interessa mais propriamente aqui, a procura por uma exterioridade que recusa adotar um objeto já pronto, mas propõe-se a "apreender o movimento pelo qual se constituía através dessas tecnologias movediças um campo de verdade com objetos de saber." ${ }^{\prime 199}$

Neste sentido, a tragicamentalidade é mesmo este tipo de objeto, que não está já pronto, sendo igualmente uma noção problemática, artificial, obscura, fraca, difusa e lacunar.

Da mesma forma que Foucault propõe a noção fraca de governamentalidade para abordar as noções fortes e consistentes de Estado e população, exatamente para desestabilizar estas últimas; é que também proponho esta fraca noção de tragicamentalidade, para desestabilizar, não chega a tanto minha pretensão, mas, ao menos, para estremecer a noções bastante fortes e consistentes de Clínica e saúde.

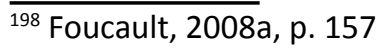

199 Ibidem, p. 158
} 
Mas que método seria possível para abordar então objetos não prontos, mas em construção processual ao longo da própria trajetória investigativa?

É Foucault ainda a propor que:

“(...) é verdade que nenhum método deve ser, em si, uma meta. Um método deve ser feito para nos livrarmos dele. Mas trata-se menos de um método do que de um ponto de vista, de um acomodamento do olhar, uma maneira de fazer o [suporte(?)] das coisas girar pelo deslocamento de quem as observa. Ora, parece-me que tal deslocamento produz certo número de efeitos que merecem, se não ser conservados a qualquer preço, pelo menos mantidos o máximo que se puder."200

É um método como tal, como ponto de vista em deslocamento, que Foucault utiliza para demonstrar justamente como uma experiência de método - que esta sua análise da governamentalidade não é a única possibilidade de análise, mas uma das possibilidades suficientemente fecundas e promissoras.

Comecei, portanto, esta investigação, tendo gerado este quase objeto que inicialmente chamei "a estética do trágico". Mas, logo de início, a discussão nestes termos foi demonstrando sua formidável capacidade de gerar mal entendidos. Isto porque, a referência ao trágico na produção do cuidado em saúde mental, suscitava logo a ideia pré-concebida do trágico como o desastre do adoecimento, como o catastrófico do sofrimento do adoecer e morrer. E como não era a isto que intencionava me referir quando utilizo o trágico na produção do cuidado, me pareceu bastante oportuno adotar a obscura noção de tragicamentalidade na produção do cuidado.

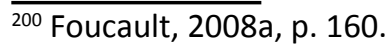


Esta noção tragicamentalidade desfrutando, por sua vez, da vantagem de ser tão obscura que não suscitava mais os mal entendidos pré-concebidos, mas restando em total desentendimento. Dando-me assim, a oportunidade de esclarecer que construo esta noção a partir do conceito de trágico como estabelecido especificamente na obra de Nietzsche, desde seus textos inaugurais "Introdução à Tragédia de Sófocles" e "O Nascimento da tragédia ou Helenismo e Pessimismo".

Falar em tragicamentalidade me permite, além de construir a referência ao trágico como dimensão paradoxal dionisíaca e apolínea inerente ao humano, também uma construção conceitual como uma referência direta, ainda que pelo avesso, à governamentalidade.

Isto considerando a governamentalidade como, repito aqui novamente:

“(...) o conjunto constituído pelas instituições, os procedimentos, análises e reflexões, os cálculos e as táticas que permitem exercer essa forma bem específica, embora muito complexa, de poder que tem por alvo principal a população, por principal forma de saber a economia política e por instrumento técnico essencial os dispositivos de segurança."201

Neste sentido, é que procuro abordar uma estética, que podemos chamar, com Nietzsche, de socrática, reinante na clínica hegemônica em saúde mental, como parte integrante da governamentalidade; contrapondo a esta, uma outra estética, a da tragicamentalidade na produção do cuidado, que estaria atuando simultaneamente, na ambivalência do agir em saúde.

Parti, portanto, desta noção obscura, deste objeto-

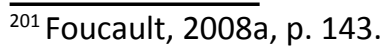


quase, a ser constituído processualmente, com uma metodologia que é, apenas, um olhar em deslocamento permitindo outras visibilidades.

Tal situação compõe, ao mesmo tempo, uma fragilidade e uma flexibilidade metódica, de forma que me sinto numa posição de pesquisador simultaneamente fortemente potente, mas altamente vulnerável.

Para ilustrar esta condição recordo da magnífica série acerca do Minotauro produzida por Pablo Picasso desde 1928, mas, sobretudo, a fase de 1934, em que encontramos o sobrepotente e aterrador Minotauro, agora cego, sendo docilmente conduzido por uma menina.

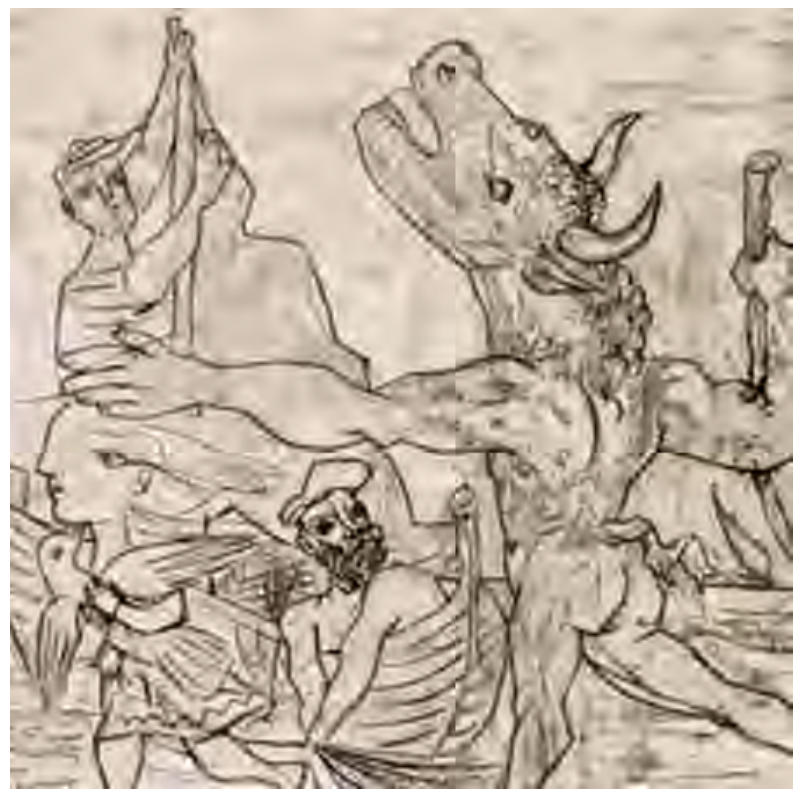

Fonte: Minotauro cego guiado por uma menina (3). PICASSO, Pablo. Gravura, 1934. (Foto: Google) 


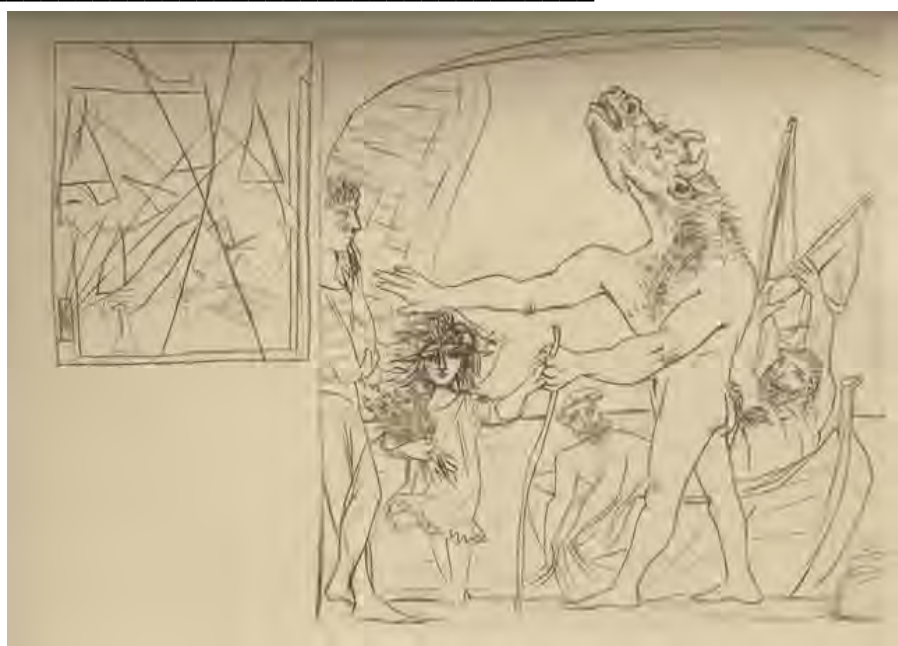

Fonte: Minotauro cego guiado por uma menina (2). PICASSO, Pablo. Gravura, 1934. (Foto: Google)

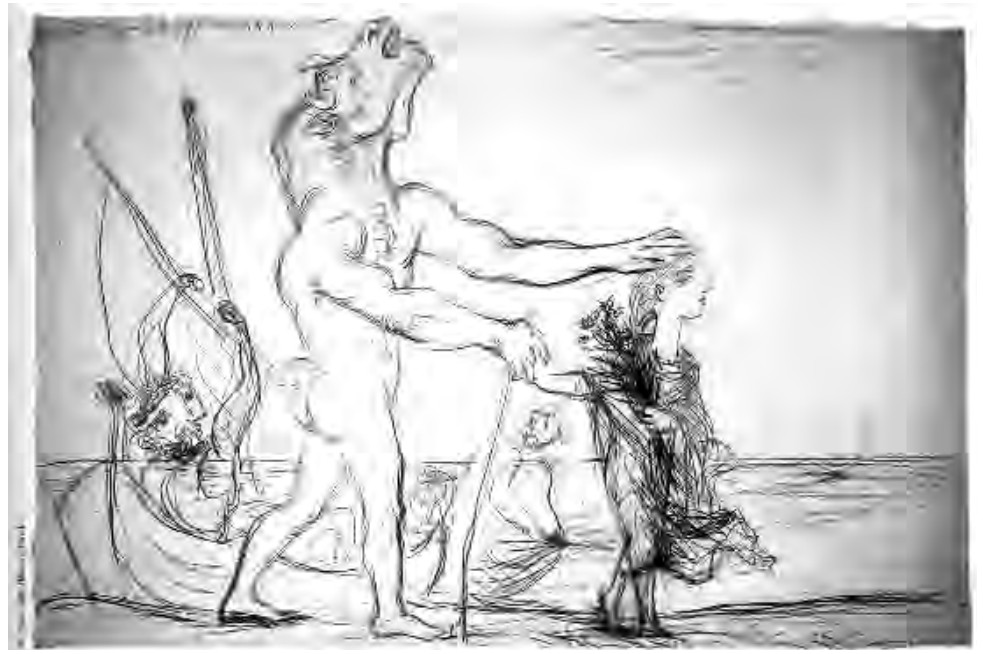

Fonte: Minotauro cego condizido por uma criança. PICASSO, Pablo. Gravura, 1934. (Foto: Google) 

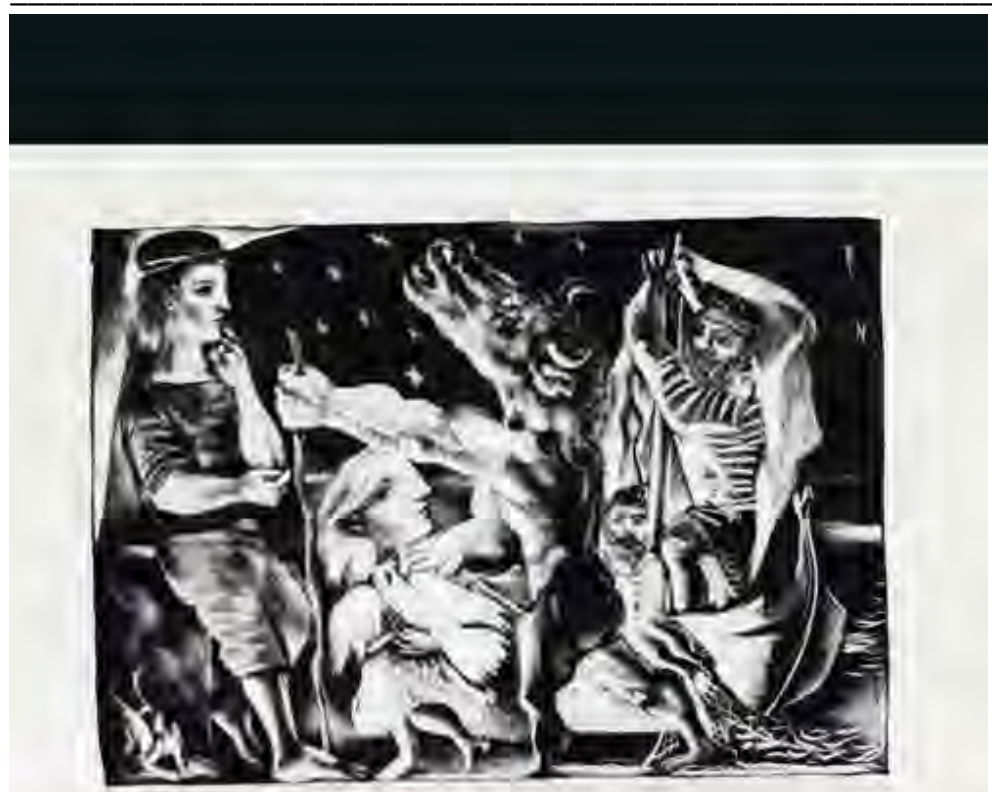

Fonte: Minotauro cego guiado por uma menina com pomba. PICASSO, Pablo. Gravura, 1934. (Foto: Museu Britânico/EFE)

Recorro a esta iconografia como forma incomparável de demonstrar um posicionamento metodológico que pode parecer à deriva, mas que simplesmente se deixa guiar por outras possibilidades que não a recomendada visibilidade científica tradicional que exige a previsibilidade, ou seja, a pré-visibilidade de tudo que concernirá àquele objeto de pesquisa, criando uma impossibilidade de surpreender-se, já denunciada por Thomas Kuhn ${ }^{202}$ como o encarceramento metódico, que permite avançar mais em sua falha que em sua perfeição aplicada.

Ao mesmo tempo, esta mesma iconografia já fala $\overline{202}$ Stengers, 2002. 
deste objeto tragicamentalidade na produção do cuidado, ao insinuar esta necessidade de uma condução pelo cuidado-menina, desta potência criadora, mas também devastadora, deste ser meio homem, meio touro, dionisíaco e apolíneo, que certamente faz lembrar os Centauros citados por Nietzsche, mas vai além, porque neste Centauro invertido é justamente a cabeça que está perdida nesta minotauromaquia, enquanto no Centauro restava esta possibilidade racional, aqui só a terrível cegueira detém a fúria e a deixa sob os cuidados da menina que agora pode comandar a fera. Sendo assim, é a sensível delicadeza e não a razão que pode orientar e conduzir a besta humana.

É comum associarem esta cena, obsessivamente reproduzida por Picassso, com a condição do próprio Édipo sendo conduzido cego por sua filha Antígona para além dos portões de Tebas, consumando seu desfecho final; ou, também, com a própria condição de Picasso em suas difíceis e tumultuadas relações com as mulheres. Mas, a força expressiva desta produção encontra uma universalidade da condição humana inegavelmente aterradora e reveladora.

Reveladora também da possibilidade de construção do saber, tendo no pesquisador esta menina que deve emprestar seus olhos possibilitando aos objetos exercerem suas potências e apresentarem suas possibilidades, que sem seus olhos emprestados ficariam perdidas ou omitidas.

Ainda um último tema iconográfico me auxilia nesta definição metodológica. Um tema clássico da pintura Sumiê japonesa, que apresenta repetidamente um homem cego, ou, em alguns pintores, três homens cegos atravessando uma ponte. 


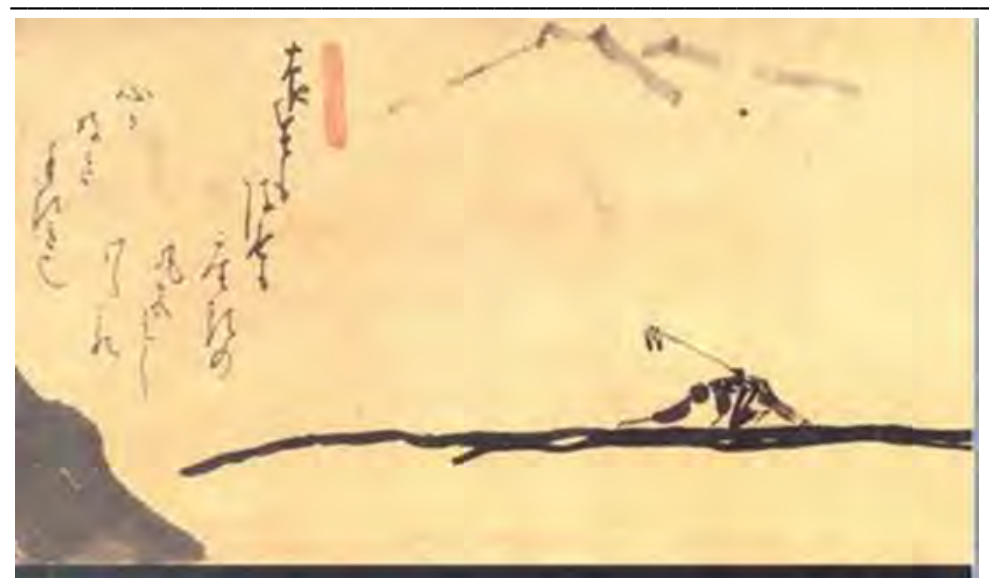

Fonte: Arte Sumiê Homem Cego Atravessando a Ponte - Mestre Zen Rinzai, Hakuin

Que síntese fabulosa é esta do desafio e, ao mesmo tempo, da inexorável necessidade do conhecimento. Uma vez que precisa o homem seguir em frente, retirando humildemente suas sandálias, e cuidadosamente apalpando esta ponte precária do saber, que não o levará ao outro lado sobre o abismo, mas ainda assim precisa ser trilhada.

Parto então em busca de alguns marcos teóricos que possam me direcionar, marcas neste tronco que me deem pistas por onde seguir com alguma segurança, que me permitam seguir adiante.

E neste sentido, um marco teórico decisivo para esta investigação é a produção de Isabelle Stengers, a propósito da invenção e validação das ciências modernas.

Esta autora retoma o debate das ciências desde o II Congresso Internacional de História da Ciência e da Tecnologia, de 1931, com seus desdobramentos sobre "a função social das ciências", cujo defensor típico teria sido John D. Bernal, influenciado pelo marxismo, apostando "(...) em que a produção científica e os interesses sociais 
e econômicos são mostrados como solidários de fato e de direito." 203

Stengers vai acompanhando este debate que passa, na década de cinqüenta e sessenta, pela reivindicação de autonomia da ciência, através da extraterritorialidade desta e pela competência dos cientistas, submetidos ao controle de seus pares, posição representada pelos escritos de Michael Polanyi, e problematizada por Thomas Kuhn, com suas proposições de ciência normal e revolução paradigmática, e confrontada pela corrente "demarcacionista, cuja origem está associada ao nome de Karl Popper"204, com suas investigações sobre a lógica da descoberta científica, seus critérios de verificabilidade e falseabilidade.

Mas o propósito de Stengers é chegar às críticas desconcertantes da "antropologia das ciências", de Bruno Latour e Michel Callon, ousando escandalosamente "estudar a ciência à maneira de um projeto social como outro qualquer, nem mais descolado das preocupações do mundo, nem mais universal ou racional do que qualquer outro."205

Não se trata mais de denunciar as infidelidades ou irregularidades cometidas contra as sacrossantas regras da objetividade, da imparcialidade, da autonomia, mas de considerá-las "puramente" vazias em seu ideal. Instituindo, como método investigativo o princípio da simetria, que consiste em "tirar as conseqüências do fato de que nenhuma norma metodológica geral pode justificar a diferença entre vencedores e vencidos criada pelo encerramento de uma controvérsia." 206

\footnotetext{
203 Stengers, 2002, p. 15.

${ }^{204}$ Ibidem, p. 38.

${ }^{205}$ Ibidem, p. 11.

${ }^{206}$ Ibidem, p. 17.
} 
Desta forma, temos um aprofundamento crítico desvelando o cientista não mais apenas como "produto de uma história social, técnica, econômica, política como qualquer ser humano"207, mas ator de sua época, não apenas produto, tomando partido, buscando recursos e estratégias para fazer prevalecer suas posições nas controvérsias de seu tempo, dissimulando-se detrás da objetividade ou da racionalidade.

Ao longo desta proveitosa revisão, esta autora vai alinhavando a construção conceitual das "testemunhas verídicas", "casos ilustrativos" que, "como se diz em matemática: eles não estão aí para provar e sim para explorar a maneira pela qual descrevemos as situações" ${ }^{\prime 208}$, ou, enfim, das "testemunhas fidedignas".

É esta categoria conceitual que tomo de empréstimo, por aproximação e de forma imprecisa, sobretudo sem entrar na polêmica da fidedignidade das testemunhas criadas no percurso das ciências ${ }^{209}$, para a construção metodológica deste estudo, construindo testemunhos fidedignos que possam explorar e demonstrar os acontecimentos na produção do cuidado em saúde mental, preservando ou respeitando sua complexidade, e apontando a tragicamentalidade em ato.

Se, por um lado, pode-se considerar que este recurso à testemunha fidedigna guarda semelhança estreita com a construção do caso clínico em saúde mental, como recurso demonstrativo da prática clínica operante em dado serviço de saúde, em um certo número de tratamentos acontecidos; por outro lado, guarda também importantes diferenças, por não estar centrado, como pretendo demonstrar, na estrutura tradicional da descrição patológica ou psicopatológica, da

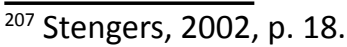

${ }^{208}$ Ibidem, p. 29.

${ }^{209}$ Stengers, 1990. 
classificação nosológica ou diagnóstica, e muito menos ainda, das definições etiológicas, que caracterizam, em geral, a elaboração de casos clínicos.

Outro ponto decisivo para a metodologia deste estudo é, considerando minha participação na construção prática de produção de cuidado, a definição do conhecer militante do sujeito implicado, como proposto por Emerson Merhy. ${ }^{210}$

Em um verdadeiro manifesto metodológico, Merhy defende não só a possibilidade e a validade dos saberes produzidos, acerca das formas de produção de cuidado no campo da atenção à saúde, ou da formulação das políticas públicas pertinentes a este mesmo campo, pelos próprios atores dos processos estudados; mas, inclusive a pertinência e a amplitude das possibilidades que se abrem neste processo de implicação íntima e até de miscigenação entre o sujeito epistêmico e os seus objetos de pesquisa.

Ora, esta é bem a posição em que me encontro neste estudo, a de ser um dos construtores de um processo de produção de cuidado que se pretende interessante, e que, agora, intenciona a posição de sujeito epistêmico frente a, ou nesta produção de saberes emergentes deste mesmo processo, no sentido da:

\footnotetext{
“(...) produção de um conhecer militante de um sujeito implicado que quer este saber para perceber a si, enquanto um coletivo em ação transformadora, com êxitos mudancistas ou não, procurando mapear como isto é possível e, ao mesmo tempo, socializar estes seus saberes e agires transformadores." 211
}

${ }^{210}$ Merhy, 2004.

${ }^{211}$ Ibidem, p. 30. 
Desta contribuição de Merhy quero destacar três pontos que já ressaltei anteriormente em minha dissertação de mestrado ${ }^{212}$, sendo os que se seguem.

O primeiro refere-se ao fato de que:

“(...) o sujeito que interroga é ao mesmo tempo o que produz o fenômeno sob análise e, mais ainda, é o que interroga o sentido do fenômeno partindo do lugar de quem dá sentido ao mesmo, e neste processo cria a própria significação de si e do fenômeno. Ou mais, ao saber sobre isso mexe no seu próprio agir, imediatamente e de maneira implicada; chegando ao ato de intencionar o conhecimento através de um 'acontecer nos acontecimentos' $(. . .)^{\prime 213}$

Neste aspecto, o foco deste estudo sobre a produção do cuidado em saúde mental, sobretudo como operada por mim em minha prática, me coloca inevitavelmente no centro das interrogações que me proponho a fazer, com a possibilidade real de implicações diretas no meu próprio agir cotidiano, correndo riscos e abrindo oportunidades auto-analíticas.

O segundo aspecto é que:

"Neste tipo de estudo o mais importante do ponto de vista metodológico é a produção de dispositivos que possam interrogar o sujeito instituído no seu silêncio, abrindo-o para novos territórios de significação, e com isso, mais do que formatar um terreno de construção do sujeito epistêmico, aposta-se em processos que gerem ruídos no seu agir cotidiano, pondo-o sob análise. Aposta-se na construção de dispositivos auto-analíticos que os indivíduos e os coletivos em ação

${ }^{212}$ Moebus, 2008.

${ }^{213}$ Merhy, 2004. p. 31. 
possam operar e se auto-analisar."214

Nesta perspectiva, este estudo intenciona construir uma categoria conceitual a propósito da estética do trágico, a tragicamentalidade, que possa exatamente servir como geradora de ruídos, abrindo novas significações sobre a produção do cuidado em análise.

O terceiro aspecto é o paralelo:

“(...) à vivência que temos no plano individual com o sonho, que muitas vezes aparece para nós como um outro, como algo que é ruidoso, mostrando 'falhas' no nosso mundo da identidade, das significações, em que construímos nosso território existencial como o lugar de uma certa referência identitária e de desempenho de certos papéis, onde achamos que ali sabemos quem somos e onde capturamos estes processos diferentes, estranhos. Aí, em um sonho, percebemos que um outro em nós se revela, mostrando que aquele mundo de significações onde nos encontramos, definindo-nos e aos outros, pode ser 'esburacado', pois tudo que já tinha um sentido pode começar a se revelar sem sentido, ou mesmo a mostrar outros sentidos e, em alguns casos, este outro vem com tal força que a 'captura' mostra-se difícil."215

Nesta direção, tentar abrir esta verdadeira "caixa preta" das escolhas estéticas em ação na produção do cuidado, buscando uma leitura que não se identifique clínica, eviscerando acontecimentos terapêuticos, já seria suficientemente arriscado.

Mas, tentar uma condensação disto na noção de tragicamentalidade, pode mesmo vir a ser um

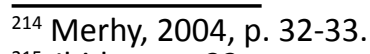

${ }^{215}$ Ibidem, p. 33. 
verdadeiro recurso onírico gerador de estranhamento, do tipo indispensável para permitir descobertas de novos territórios, novas visibilidades, novos enunciados sobre si e os outros; como, por exemplo, não mais "o que pode a clínica?", mas agora: o que podemos além da clínica? 



\section{V - Cuidado}

O que nos move na vontade de produzir cuidado?

Quero retomar aqui, esta mesma pergunta feita por Luiz Fuganti, em seu texto "Biopolítica e produção de saúde - um outro humanismo?"216

Mas, se por um lado, essa me parece uma pergunta preciosa, que interessa intensamente a este estudo, por outro, quero retomá-la aqui, de forma bastante distinta daquela construída por Fuganti.

Essa pergunta se desdobra em algumas outras que, como se verá aqui, encontram ressonância com este trabalho, mas de uma forma certamente não coincidente, como nos questionamentos abaixo, ainda com Fuganti:

"Não haveria um biopoder radicalmente diferente de uma biopotência? Não deveríamos apreender o que comanda na vida? Em qual vida? Cultivamos a vida reativa em nós? Queremos dar saúde à vida reativa? Queremos dar saúde e vida longa à vontade que se nega ao negar, que se arrasta e prolifera modos tristes de existir? Queremos que esse homem produzido essencialmente em sua forma reativa se conserve? ${ }^{217}$

${ }^{216}$ Fuganti, 2008.

217 Ibidem. 
Tais perguntas, sobretudo porque lançadas aos trabalhadores da saúde, podem obter efeitos bastante interessantes, entre eles, o de oferecer esta diferença entre biopoder e bipotência, diferença entre vida ativa/criativa e vida reativa, diferença entre modos tristes de existir e modos alegres de existir.

Mas qual seria o marcador destas diferenças? Sobretudo destas diferenças nos outros, porque em mim mesmo, sinto-me mais à vontade para defini-las. Posso definir com mais propriedade os meus modos tristes e os meus modos alegres de existir.

Mas, quando se trata desta definição nos outros; por exemplo, desta definição ser feita por mim, enquanto trabalhador, operário da saúde, nos usuários da saúde; aí as coisas ficam bastante delicadas, diria até arriscadas. Porque isto pode querer dizer, em última instância, que eu defina quais as vidas que valem a pena, porque são modos alegres de existir, e quais as que não valem a pena, porque são modos tristes de existir, segundo critérios meus.

Sei, outrossim, que esta diferenciação é proposta de uma maneira responsável por Fuganti, dentro de um contexto, inclusive teórico, que condena todo moralismo, que desconfia de todo julgamento do bem e do mal, afiliando-se a uma crítica que inclui Nietzsche, com sua genealogia da moral ${ }^{218}$, e seu projeto de superação do bem e do mal. ${ }^{219}$

Sei, também, que esta diferenciação, apóia-se em Espinosa, referindo-se à Ética - Demonstrada à Maneira dos Geômetras ${ }^{220}$, com sua perspectiva de potência da vida como grande fiel da balança das afecções, dos bons e maus encontros; sobretudo, com a leitura apresentada por

\footnotetext{
218 Nietzsche, 2009.

219 Nietzsche, 2008a.

${ }^{220}$ Espinosa, 1983.
} 
Deleuze, em seu, Espinosa ${ }^{221}$.

Também percebo que esta diferenciação baseia-se nos conceitos de biopoder ${ }^{222}$ e bipolítica ${ }^{223}$, como os pensou Foucault; e que sugere uma referência ao conceito "vida nua"224, como o esclareceu Agamben; e que trabalha ainda com a possibilidade de se pensar uma biopotência ${ }^{225}$.

Mesmo assim, reconheço aí dois pontos fundamentais de discordância com a maneira como a pergunta sobre o cuidado se fará aqui.

E tomo a liberdade de me valer deste texto, de um autor que me é muito caro, para, partindo desta diferenciação, poder explicitar melhor minha própria posição.

Em primeiro lugar, mesmo com as ponderações que fiz acima, e apesar delas, discordo da proposta de que uma vida reativa - com seus modos tristes de existir, com sua vontade que se nega ao negar - não merece ser cuidada, ou preservada.

Ainda que, se deixe bem explicado que, ao dizer que uma vida reativa não deve ser conservada, tem-se em mente não a idéia de eliminá-la, mas que, apenas ela não deve ser conservada nesta sua forma, ou seja, ela deve ser mudada, ou transmutada em uma vida ativa/criativa, mais potente.

Mesmo assim, acho preocupante e temerário, uma proposta que se autorize, seja pelas melhores referências éticas, estéticas ou políticas que forem, a discernir entre as vidas que devem e as que não devem ser conservadas. Ou ainda, que preconize modos válidos e inválidos de viver, a

\footnotetext{
${ }^{221}$ Deleuze, 2002.

${ }^{222}$ Foucault, 2005.

${ }^{223}$ Foucault, 2008b.

${ }^{224}$ Agamben, 2007.

225 Pelbart, 2003.
} 
partir de algum critério.

Então, nesta primeira diferenciação, quero esclarecer que este estudo não tem nenhuma pretensão de estabelecer um julgamento sobre, ou de apontar uma solução para, ou de determinar ou de estabelecer quais seriam os modos corretos, ou os modos melhores, ou os modos mais legítimos de se produzir saúde, de se trabalhar em saúde.

Claro que, muito menos ainda, pretende-se aqui, fazer o julgamento sobre os modos de se viver, sejam eles mais tristes, mais alegres, mais fecundos ou iracundos.

Isto não quer dizer, por outro lado, uma posição relativista, que considere que tudo vale a pena, ou que tudo vai dar no mesmo, ou, dizendo a mesma coisa pelo outro lado, que nada vale a pena, e que seja ou não o mesmo, vai dar em nada; correndo o risco de um niilismo do tanto faz como tanto fez, cada um tem sua vez, e cada signo o seu mês.

Tampouco, pretendo uma postura de lassidão, que impede a tomada de decisões e não permite assumir posições.

Que não se trata disto, que não se encontra aqui um niilismo e uma lassidão, serão testemunhas estas próprias páginas, esforço real de apresentar, com uma postura perspectivista ${ }^{226}$, e decidida, visibilidades acerca do agir em saúde, e as tomadas de decisões que estas visibilidades nos exigem, como compromisso ético-estético-político.

Então, o que pretendo aqui, ao navegar pelas práticas de produção do cuidado, que compõem meu agir em saúde, é construir uma perspectiva que ofereça novas visibilidades

\footnotetext{
${ }^{226}$ Refiro-me aqui à idéia, muito cara a Nietzsche, de um perspectivismo que possa combater a idéia de verdade absoluta, sem, contudo, cair no niilismo. Ver Souza (2009, p. 339): “(...)que não existem fatos ou verdades, apenas interpretações ou perspectivas."
} 
sobre elas, e que permitam sim a elaboração de opiniões e a tomada de decisões. Mas, sem querer revelar uma "verdade", que pretenda ser "a verdade" das práticas de saúde, sem pretender estabelecer um critério, que seja o julgamento das boas e das más práticas de saúde.

Sem pretensões de verdades universais ou últimas, por um lado, e, esperando que isto sirva, que isto faça nexo, faça sentido, para além de mim, por outro. Desta maneira, me disponho a apresentar os instrumentos com os quais trabalho em saúde mental, atravessando três clínicas: a psiquiátrica, a psicanalítica, a psicossocial; vistas aqui pela perspectiva do trágico.

O segundo ponto fundamental de discordância entre a maneira como se pergunta aqui sobre o cuidado, e a maneira perguntada por Fuganti, diz respeito propriamente ao cuidado.

Quando Fuganti pergunta: o que nos move na vontade de produzir cuidado? O que ele traz para cena referindo-se a cuidado, me parece ser, fundamentalmente, um equivalente dos fazeres e saberes clínicos e epidemiológicos.

Quando ele diz - produzir cuidado - está se referindo a algo que poderia ser perfeitamente substituído pela pergunta: $\mathrm{O}$ que nos move na vontade de clinicar? $\mathrm{Na}$ vontade de fazer clínica? Ou, na vontade do fazer clínico? Ou ainda, na vontade de planejar ou gerir serviços ou sistemas de saúde? Ou na vontade de ofertar serviços e atendimentos de saúde?

Pois bem, a interrogação dirigida aqui ao cuidado, não coincide com isto. $O$ que quero trazer para cena, referindome ao cuidado, é algo que, sendo a alma dos serviços de saúde, ao mesmo tempo, não coincide com eles, não se resume a eles, não se restringe aos fazeres e saberes clínicos e epidemiológicos. 
Ou seja, o cuidado "vaza" a clínica, a epidemiologia, o planejamentoemsaúde, a prevençãoea promoçãoemsaúde; o cuidado, a produção do cuidado é um acontecimento, que pode ter lugar ou não nas práticas clínicas, no agir em saúde, mas que extrapola sua intencionalidade, sua racionalidade, sua técnica, sua previsibilidade.

Quando interrogo o cuidado, portanto, estou criando uma alteridade em relação aos saberes e fazeres clínicoepidemiológicos. Uma alteridade que não se rende, que não se deixa aprisionar à clínica, seja ela clínica ampliada ${ }^{227}$ ou não.

O cuidado interrogado aqui é, desta forma, bastante outro que o interrogado por Fuganti. É também, uma peça chave, que pretendo articular com os conceitos de tragicamentalidade e governamentalidade, como explicitados acima.

É com esta tríade, que pretendo montar um trinóculo, que me permita outras visibilidades que possam estar além do "olho ciclópico" dos racionalismos socráticos ${ }^{228}$, como descrito por Nietzsche, e além dos binóculos, sejam psicossociais, sejam das clínicas ampliadas.

Para entendê-lo melhor, o cuidado, recorro aqui à produção de Emerson Merhy, que tem se debruçado sobre o tema em textos como "O ato de cuidar: alma dos serviços de saúde?" 229 e "O ato de cuidar como um dos nós críticos 'chaves' dos serviços de saúde" ${ }^{230}$, dentre outros.

É a partir das ofertas de Merhy que podemos pensar a dimensão cuidadora, como pertinente aos serviços de saúde, pertinente aos atos de saúde, pertinente ao processo

\footnotetext{
227 Campos e Amaral, 2007.

${ }_{228}$ Nietzsche, 2005a, p.87.

${ }^{229}$ Merhy, 1999.

${ }^{230}$ Merhy, 1999a.
} 
de produção da saúde, mas não coincidente com estes.

Em particular, a dimensão cuidadora aparece em contraposição à geração, execução de procedimentos, que podem muitas vezes restringir o agir em saúde a um mero trabalho repetitivo, esvaziado de sua dimensão de encontro.

Então, o cuidado traz para cena uma variedade de questões em relação ao processo de produzir saúde. Primeiro, que a produção no campo da saúde coincide com seu consumo. Segundo, que o trabalho em saúde apresenta uma prerrogativa de ser eminentemente trabalho vivo em ato. Terceiro, que o trabalho em saúde é um trabalho baseado no encontro, e que o cuidado é um acontecimento, que pode ter lugar nesse encontro.

O cuidado então, estando no coração do agir em saúde, do trabalho em saúde, vai se delineando como algo que se obtém, ou que acontece, ou que opera simultaneamente, mas não coincidindo com os procedimentos, com o que se executa neste agir em saúde.

Podemos pensar, imprecisa e analogamente, no cuidado como uma "mais-valia" do trabalho em saúde. No sentido de ser algo que se viabiliza a partir do processo de trabalho, que resulta do processo de trabalho, que pode existir no processo de trabalho como um excedente, como uma produção de riqueza deste processo de trabalho, mas que não é evidente, não é palpável à primeira vista, pertencendo às materialidades incorpóreas ${ }^{231}$, às linhas de fuga ${ }^{232}$.

Cabem aqui alguns esclarecimentos necessários, sendo o primeiro que, quando faço esta analogia com a "mais-valia", é preciso dizer que não me refiro ao aspecto

${ }^{231}$ Deleuze; Guattari, 2008.

${ }^{232}$ Deleuze; Guattari, 2008a. 
exploratório que a mais-valia representa. Ou seja, o cuidado não é um resultado de uma exploração do trabalhador. Pelo menos, não no sentido corriqueiro a que se refere uma exploração.

Mas podemos dizer, explorando um pouco mais este sentido de exploração, que sim, que o cuidado resulta da exploração do trabalhador de saúde, e do usuário de saúde também.

Isto, no sentido que, o cuidado seria uma resultante, necessariamente quando o agir em saúde constitui um encontro. Sendo assim, para que um encontro aconteça, é preciso que o trabalhador de saúde saia de si mesmo e vá explorar os territórios desconhecidos oferecidos pelo usuário. E, da mesma forma, é preciso que o usuário saia de si mesmo, e vá explorar os territórios desconhecidos oferecidos pelo trabalhador.

Então, o cuidado pode acontecer quando temos trabalhador e usuário que sejam exploradores, que sejam desbravadores de terras desconhecidas, e também que sejam, simultaneamente, territórios explorados.

Para o cuidado vir a ser, este acontecimento singular e plural, é preciso que trabalhador e usuário sejam exploradores e explorados.

Nestes termos, posso dizer: o cuidado é a "mais-valia" resultante da exploração dos trabalhadores de saúde, e dos usuários também.

Perdoem-me os Marxistas, mas vejamos se este conceito mais-valia serve aqui, funciona aqui, de uma forma certamente retorcida.

Marx explica a produção de valor no processo de trabalho, a produção de valor-de-uso e valor-de-troca, 
a transformação em mercadorias, a produção de um excedente:

"Além de um valor-de-uso, quer produzir mercadoria; além de valor-de-uso, valor, e não só valor, mas também valor excedente (mais-valia)." ${ }^{233}$

Marx então descortina o segredo da mais-valia:

"Comparando o processo de produzir valor com o de produzir mais-valia, veremos que o segundo só difere do primeiro por se prolongar além de certo ponto. $O$ processo de produzir valor simplesmente dura até o ponto em que o valor da força de trabalho pago pelo capital é substituído por um equivalente. Ultrapassando esse ponto, o processo de produzir valor torna-se processo de produzir mais-valia (valor excedente)."234

E Marx explica a conexão da mais-valia com a produção do capital, quando faz uma pequena ironia, fazendo uma conta na qual alguns quilos de fio fossem vendidos por seu valor "real":

\begin{abstract}
"Nosso capitalista fica perplexo. O valor do produto é igual ao do capital adiantado. $\mathrm{O}$ valor adiantado não cresceu, não produziu excedente (mais-valia); o dinheiro não se transformou em capital." 235
\end{abstract}

Tomo a liberdade, ou a licença poética, se preferirem, de pensar, a partir deste conceito de mais-valia, o cuidado.

É que a mais-valia depende fundamentalmente de que, primeiramente, o produto do trabalho com seu valor-de-uso, seja convertido em uma abstração, em uma

233 Marx, 2004. p. 220.

${ }^{234}$ Ibidem, p. 228.

${ }^{235}$ Ibidem, p. 224. 
materialidade incorpórea, a mercadoria, com seu valor-detroca.

E depende, em segundo lugar, que haja a produção de um valor excedente, que significará produção de capital.

Ora, no processo de trabalho da produção dos atos de saúde, temos também a produção de valor-de-uso, por exemplo, produção de um curativo em uma ferida de um pé diabético, que terá grande valor-de-uso para o usuário da saúde. E também produção de valor-de-troca, ou seja, quanto vale aquela prestação de serviço, fazer um curativo, com seu caráter de serviço especializado, ou diferenciado, ou qualificado, com o valor agregado dos materiais utilizados, em certo contexto sócio-cultural, em dada sociedade comercial, em um certo momento histórico, num dado cenário de oferta e procura no mercado, etc. E também, a produção de uma mais-valia, stricto sensu, digamos assim, se, a partir daquele trabalhador há a produção de uma acumulação financeira por outro além dele.

Convém lembrar que as relações que envolvem a produção de saúde e o funcionamento dos mecanismos capitalistas, com a reprodução de força de trabalho, com a produção de corpos dóceis, com a normalização da sociedade, com a mercantilização da vida, com a medicalização, com a medicamentalizaçao, etc, etc, etc; são muito mais complexos, do que estou analisando.

Mas, não é este meu objetivo aqui. O ponto é, tão somente, lançar mão desta analogia, para dizer que, no processo de trabalho da produção da saúde, além do valorde-uso, do valor-de-troca, da mais-valia stricto sensu, há ainda a produção de um outro excedente.

É que, pode acontecer neste processo de trabalho em saúde, a produção deste outro excedente, a produção 
do cuidado, produção dessa mais-valia geradora de vida, vida capital. ${ }^{236}$

Este foi um primeiro esclarecimento, sobre maisvalia e cuidado. Preciso ainda fazer um segundo e terceiro, sobre o que disse acima, do cuidado como materialidade incorpórea e como linha de fuga.

Utilizo a idéia do cuidado como materialidade incorpórea ou incorporal, na concepção ofertada por Deleuze e Guattari:

\begin{abstract}
"Mas, se o agenciamento não se reduz aos estratos, é porque nele a expressão tornase um sistema semiótico, um regime de signos, e o conteúdo, um sistema pragmático, ações e paixões. É a dupla articulação rostomão, gesto-fala, e a pressuposição recíproca entre ambos. Eis, portanto, a primeira divisão de todo agenciamento: por um lado, agenciamento maquínico, por outro, e ao mesmo tempo, agenciamento de enunciação. Em cada caso é preciso encontrar um e outro: o que se faz e o que se diz? E entre ambos, entre o conteúdo e a expressão, se estabelece uma nova relação que ainda não aparecia nos estratos: os enunciados ou as expressões exprimem transformações incorporais que se atribuem como tais (propriedades) aos corpos ou aos conteúdos." 237
\end{abstract}

Então, o cuidado, como transformação incorpórea ou incorporal, resultante de uma nova relação, a partir de agenciamentos - entre trabalhador e usuário da saúde capazes de disparar novos regimes semióticos na vida de ambos.

\footnotetext{
${ }^{236}$ Pelbart, 2003. Desenvolve este conceito de "vida capital" para pensar as relações entre o poder sobre a vida e a potência da vida.

${ }^{237}$ Deleuze; Guattari, 2008, p.218-219.
} 
Como terceiro esclarecimento, dizer que o cuidado opera como uma linha de fuga, ou, em linha de fuga, também é trazer uma referência deleuziana:

"Do ponto de vista da micropolítica, uma sociedade se define por suas linhas de fuga, que são moleculares. Sempre vaza ou foge alguma coisa, que escapa às organizações binárias, ao aparelho de ressonância, à máquina de sobrecodificação: aquilo que se atribui a uma 'evolução dos costumes', os jovens, as mulheres, os loucos, etc." 238

Neste sentido, o cuidado funcionaria como linha de fuga que vaza a clínica, para além da molaridade médica, na possibilidade molecular do encontro, escapando à máquina de sobrecodificação da medicalização da vida.

Convém esclarecer, neste ponto, que Deleuze e Guattari procuram estabelecer duas dimensões que estariam compondo, de forma integrada, a existência, que são a molaridade e a molecularidade, com certo grau de equivalência com a macropolítica e a micropolítica:

"Toda sociedade, mas também todo indivíduo, são pois atravessados pelas duas segmentaridades ao mesmo tempo: uma molar e outra molecular. Se elas se distinguem, é porque não tem os mesmos termos, nem as mesmas correlações, nem a mesma natureza, nem o mesmo tipo de multiplicidade. Mas, se são inseparáveis, é porque coexistem, passam uma para a outra, segundo diferentes figuras como nos primitivos ou em nós - mas nem sempre uma pressupondo a outra. Em suma, tudo é político, mas toda política é ao mesmo tempo macropolítica e micropolítica." ${ }^{239}$

$\overline{238}$ Deleuze; Guattari, 2008a, p. 94.

${ }^{239}$ Ibidem, p. 90. 
O cuidado então estaria nesta perspectiva de linha de fuga, micropolítica do encontro trabalhador - usuário em saúde, viabilizando possibilidades imprevistas, incalculáveis, a partir de "bons encontros" que possam ampliar a "latitude" dos envolvidos:

"Entendemos por latitude o conjunto dos
afetos que preenchem um corpo a cada
momento, isto é, os estados intensivos de
uma força anônima (força de existir, poder de
ser afetado)." ${ }^{240}$

Podemos pensar ainda, no cuidado como uma terceira margem da clínica, como um limite à clínica, que permita à vida acontecer para além da clínica, não se submetendo à racionalidade, à praticidade, à tecnologia clínica.

O efeito "terceira margem" cunhado por João Guimarães Rosa em seu texto "A Terceira Margem do Rio" 241 aponta para o permanecer entre, inter, um deslizamento que não se interrompe como previsto, nem onde previsto, uma desterritorialização, uma intensidade, um envolvimento em-movimento, uma permanência, um fluxo em corte em fluxo, um prolongamento, algo que, como os "Platôs" de Deleuze, viabiliza um estado que não se ancora nas duas margens habituais, mas que não diz apenas de um alargamento, de uma ampliação, mas de um mais ainda margeado; a terceira margem apresenta uma dimensão insuspeitada sim, um há mais do que se pensava, mas para por margem, delimitar, circunscrever esta novidade, ali mesmo onde nem havia, é preciso que haja com limite.

Assim, uma terceira margem para uma clínica que seque seu curso pluridimensional, mas deve ser limitada em todas suas dimensões, para não ser absolutista, para não colonizar a vida em todos os seus aspectos, para não ${ }^{240}$ Deleuze, 2002, p. 132-133.

${ }^{241}$ Guimarães Rosa, 1988. 
fazer da vida uma clínica, para não colocar a vida a serviço da clínica, mas no seu devido incerto lugar colocar a clínica a serviço do viver a própria vida, entendendo que deve ser ampliada a vida, antes que a clínica; pois, se clinicar é preciso, viver é impreciso e mais.

Sobretudo, se pensarmos a clínica, as tecnologias clínicas, como estratégias ou táticas componentes da governamentalidade, ou seja, a serviço da regulamentação da vida. Aí então, podemos pensar o cuidado como aquilo que não está submetido a esta lógica de regulação da vida, que não está a serviço desta lógica, mas que acontece no momento e no processo mesmo que esta lógica faz operar.

Para entender isto será necessário romper esta visão do campo da saúde que habitualmente cria uma homogeneização de seus processos, buscando enxergar suas ambivalências, paradoxos, duplicidades, heterogeneidades, complexidades.

Para tanto, recorro a alguns conceitos, que vem sendo construídos e ofertados por Emerson Merhy, para pensar o campo da saúde, e que permitem ampliar sobremaneira a visibilidade sobre este campo:

"Pode-se dizer que todo processo de trabalho em saúde produz "atos de saúde", que perseguem a "produção do cuidado". E que este, conforme as linhas de interesses que the dão sentido, impostas pelos vários atores em ação na sua concretude, permitirá a realização de distintos resultados, mais ou menos comprometidos com os interesses dos usuários, mais ou menos como dispositivos liberadores ou castradores de processos autonomizantes." 242

242 Merhy, 2001. 
Merhy vem possibilitando pensar o trabalho em saúde, em suas dimensões de encontro-acontecimento, que extrapolam em muito a perspectiva tradicional, quanto a sua possibilidade criativa, quanto a sua fundamentação tecnológica, quanto ao seu grau de liberdade.

Para tanto, Merhy tem criado um campo de visibilidade sobre o agir em saúde que o considera, fundamentalmente como centrado no trabalho vivo em ato:

“TESE 7 - o trabalho em saúde é centrado no trabalho vivo em ato permanentemente, um pouco à semelhança do trabalho em educação. Além disso, atua distintamente de outros processos produtivos nos quais o trabalho vivo em ato pode e deve ser enquadrado e capturado globalmente pelo trabalho morto e pelo modelo de produção;"243

Neste ponto é preciso distinguir trabalho vivo, trabalho morto, trabalho vivo em ato:

"TESE 2 - a ação intencional do trabalho realiza-se em um processo no qual o trabalho vivo em ato, possuindo de modo interessado instrumentos para a ação, "captura" intencionalmente um "objeto/natureza" para produzir bens/produtos (as coisas/ objetos); e que pode ser esquematicamente visualizado no desenho, exemplificado a partir do trabalho de um artesão-sapateiro, que antes da realização do próprio ato produtivo já sabia aonde queria chegar, isto é, a que tipo de produto, que valor de uso estaria produzindo e, com isso, opera um ato produtivo que é amarrado por uma intenção posta anteriormente a ele; no qual o trabalho em si atua como trabalho vivo em ato e os instrumentos usados, bem como a organização do processo, como trabalho

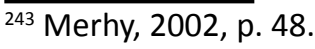


morto;"244

E esta perspectiva permitirá também pensar as dimensões tecnológicas do agir em saúde, como leves, leve-duras, e duras:

"TESE 9 - por isso as tecnologias envolvidas no trabalho em saúde podem ser classificadas como: leves (como no caso das tecnologias de relações do tipo produção de vínculo, autonomização, acolhimento, gestão como uma forma de governar processos de trabalho), leve-duras (como no caso de saberes bem estruturados que operam no processo de trabalho em saúde, como a clínica médica, a clínica psicanalítica, a epidemiologia, o taylorismo, o fayolismo) e duras (como no caso de equipamentos tecnológicos do tipo máquinas, normas, estruturas organizacionais);" 245

Essa abordagem também ressalta o grau de liberdade do agir em saúde:

"TESE 8 - o trabalho em saúde não pode ser globalmente capturado pela lógica do trabalho morto, expresso nos equipamentos e nos saberes tecnológicos estruturados, pois o seu objeto não é plenamente estruturado e suas tecnologias de ação mais estratégicas configuram-se em processos de intervenção em ato, operando como tecnologias de relações, de encontros de subjetividades, para além dos saberes tecnológicos estruturados, comportando um grau de liberdade significativo na escolha do modo de fazer essa produção;" ${ }^{246}$

${ }^{244}$ Merhy, p. 47.

245 Ibidem, p. 49.

${ }^{246}$ Ibidem, p. 49. 
Ressalta também a centralidade das tecnologias leves neste processo:

"TESE 14 - a efetivação da tecnologia leve do trabalho vivo em ato na saúde expressa-se como processo de produção de relações interseçoras em uma de suas dimensões-chave, que é o seu encontro com o usuário final, que "representa", em última instância, necessidades de saúde como sua intencionalidade, e, portanto, o que pode, com seu interesse particular, "publicizar" as distintas intencionalidades dos vários agentes em cena, do trabalho em saúde;

E ainda neste mesmo sentido:

“TESE 15 - é neste encontro do trabalho vivo em ato com o usuário final que se expressam alguns componentes vitais da tecnologia leve do trabalho em saúde: as tecnologia articuladas à produção dos processos interseçores, as das relações, que se configuram, por exemplo, por meio das práticas de acolhimento, vínculo, autonomização, entre outras;",247

E, por fim, esta abordagem do agir em saúde, que estou pegando emprestado de Emerson Merhy, ressalta a dimensão política dessa prática social:

"TESE4-nessemodo depossuir, otrabalhovivo em ato opera como uma máquina de guerra política, demarcando interessadamente territórios e defendendo-os; e, como uma máquina desejante, valorando e construindo um certo mundo para si (dentro de uma certa ofensiva libidinal);" ${ }^{248}$

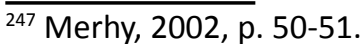

${ }^{248} \mathrm{Ibidem}$, p. 48. 
Esta abordagem ampliada do agir em saúde oferece a oportunidade de pensarmos o fazer clínico de uma forma bastante complexa, que inclui em seu processo o encontro entre trabalhador e usuário, como um acontecimento único, e aberto a inúmeras possibilidades, inclusive imprevistas pelos saberes estruturados.

Isto permite reconhecer no agir em saúde sua dimensão criativa e inventiva, e também seu jogo complexo de forças atuantes que resultará em variadas equações de exercícios de poder.

Esta perspectiva, ainda que possamos reconhecer aí uma amplificação do olhar sobre o agir em saúde, é bastante distinta do que se convencionou chamar de uma "clínica ampliada." 249

Mas, como também ressalta essa análise tecnológica do agir em saúde, a intencionalidade bastante marcada desse agir, seu compromisso com a produção de produtos/ bens, alimenta seu vínculo umbilical com o que podemos relembrar como governamentalidade:

\begin{abstract}
"TESE 11 - o trabalho vivo em ato opera com tecnologias leves como em uma dobra: de um lado, como um certo modo de governar organizações, de gerir processos, construindo seus objetos, recursos e intenções, de outro lado, como uma certa maneira de agir para a produção de bens/produtos; sendo uma das dimensões tecnológicas capturantes que dá a "cara" de um certo modelo de atenção;"250
\end{abstract}

Com isto, nosso debate vai se aproximando deste ponto no qual, se pensa não mais em uma clínica ampliada, mas em uma não clínica, em uma produção de cuidado que esteja não toda dentro da clínica. Sendo importante

${ }^{249}$ Campos; Amaral, 2007.

${ }^{250} \mathrm{Ibidem}, \mathrm{p} .50$. 
ressaltar que não se trata de nenhum antagonismo entre clínica e cuidado, mas em um extra, possível ao agir em saúde, uma dimensão extraordinária do agir em saúde.

É possível pensar nessa dimensão extraordinária do agir em saúde justamente a partir dessas visibilidades dos encontros-acontecimentos na produção do cuidado, que a perspectiva do trabalho vivo em ato e das tecnologias leves atuantes em saúde criam.

Isto ganha importância na medida em que a concepção de uma clínica ampliada apresenta um paradoxo. Por um lado é um avanço na tentativa de superar as formas tradicionais, restritas, limitadas, muitas vezes até empobrecidas, de se realizar a produção da saúde, buscando inclusive ressaltar a ética em defesa da vida.

Mas, por outro lado, esta ética em defesa da vida apresenta um risco importante, de se apropriar da vida para defendê-la. É interessante lembrarmos aqui do que esclarece Foucault em seu curso "Em Defesa da Sociedade"; o curso que antecede imediatamente o que irá definir a governamentalidade, "Segurança, Território, População".

Nestes dois cursos que relembro agora, Foucault ressalta a estratégia da segurança, o discurso da defesa, como fundamentais para o processo de expansão das intervenções governamentais que vão ampliando seu campo de intervenção, criando cada vez mais a regulamentação das formas de viver.

Este é um risco bem real apresentado pela clínica ampliada, porque a governamentalidade é um movimento de ampliação do campo disciplinar que o antecede.

A passagem da anátomo-política, com seu controle disciplinar dos corpos, para a biopolítica, com seu controle sobre toda a vida, é um movimento expansivo, não sendo 
difícil enxergar aí uma clínica ampliada. Sobretudo, se lembrarmos que um dos movimentos da clínica ampliada é levar em consideração os saberes epidemiológicos, ou seja, mais uma vez, coincidindo com o movimento de instauração da governamentalidade, que é subsidiário da invenção da população, e de sua localização no território.

Então, no limite deste raciocínio, este título: "Segurança, Território, População", que diz respeito à invenção da governamentalidade, também poderia ser usado em um manual de clínica ampliada.

É importante deixar bem claro que não estou desqualificando, muito menos desconsiderando a importância real e prática, e todos os benefícios que muito concretamente estão sendo produzidos por milhares de praticantes da clínica ampliada, junto a outros milhares de usuários de serviços de saúde.

Mas, reconhecendo seu valor, sua importância, seu mérito, seus avanços, suas qualidades, seus benefícios; quero apontar, mesmo assim, para a necessidade de se pensar no cuidado para além da clínica, na vida ampliada e na clínica restrita.

Após esta definição deste terceiro elemento, o cuidado, passo então à abordagem das práticas clínicas em saúde mental, irei agrupá-las, de forma um tanto simplificadora, e certamente imprecisa, e sobretudo injusta com a multiplicidade que constitui este campo de práticas, mas, enfim, agruparei em três grandes grupos de saberes/práticas, constituídos pelas clínicas psiquiátrica, psicanalítica e psicossocial. 
Clínica Psiquiátrica

Esta é a base que participa da constituição de quase todos ou todos os saberes/práticas do campo da saúde mental. De uma forma ou de outra, as variadas clínicas presentes na saúde mental se referem a ela, ainda que seja para negá-la.

A formação dos saberes e práticas psiquiátricas foram objeto particularmente freqüente dos estudos de Michel Foucault, e constituem justamente um certo modelo exemplar de demonstração da formação ou da genealogia do poder disciplinar, em um primeiro momento, referente especialmente ao texto "História da Loucura", já citado exaustivamente acima.

E também modelo exemplar de formação da biopolítica, da governamentalidade, do biopoder, como detalhadamente demonstrado em "O Poder Psiquiátrico" e "Os Anormais", de Michel Foucault, também citados acima.

Todavia, como estas demonstrações já foram explicitadas acima, não serão retomadas novamente aqui.

Cabe dizer, no entanto, de minha prática no exercício da psiquiatria, e neste sentido, reconheço a importância das tecnologias leve-duras (vide acima) compostas pelos saberes da psicopatologia, da nosologia, e da psicofarmacologia, e das tecnologias duras concretizadas nos medicamentos psicotrópicos.

Reconheço estes instrumentos como fundamentais e indispensáveis de minha caixa de ferramentas, enquanto operário da produção do cuidado em saúde mental.

Isto não quer dizer que desconheça a imensa e justificada quantidade de críticas sobre os excessos cometidos pela psicopatologia e nosologia, ferramentas 
que se prestam de forma excelente para a regulação, regulamentação da vida e dos comportamentos, através da psicopatologização dos afetos e dos estados do ser, que escapem à programação societária; assim como, também não desconheço os excessos cometidos pela farmacologização do sofrer e da dor de existir, gerando uma pasteurização da vida, uma sedação do desconforto, uma vida regida pela passividade, pela impotência, pela inércia, ou simplesmente, gerando consumidores dependentes.

São essas mesmas ferramentas, que gostaria de consideraralém do bem e do mal, como não necessariamente nocivas ou benéficas em si mesmas.

Cabendo ainda a ressalva que, estas ferramentas estariam no rol das mais perigosas e suscetíveis de estarem a serviço de um "afastamento da vida do que ela pode."

O que quero dizer é que, se considerarmos as tecnologias, sejam leve-duras ou duras, como não condenáveis ou louváveis em si mesmas, mas dependentes do uso que se faz delas, não significa desconhecer seus maquinismos que também são indicadores ou tendências.

Como por exemplo, se comparamos um bisturi e uma granada de mão, podemos, por um lado, considerar que qualquer um dos dois pode ser usado para matar, mas, por outro lado, não podemos também desconsiderar que a possibilidade de uma granada de mão ser utilizada para ferir alguém, para causar danos a alguém, é bem maior do que a de um bisturi, já que a granada de mão foi pensada, desenvolvida em seu design para esta intencionalidade de causar danos.

Neste sentido, acredito ter apresentado no capítulo referente a governamentalidade algo dos maquinismos que foram compondo estas tecnologias psicopatologia e 
nosologia, em suas conexões com o poder disciplinar e com o biopoder.

Mas, por outro lado, não posso ignorar uma série de dezenas de encontros meus com usuários da saúde mental, nos quais o uso de um psicofármaco foi possibilitado pela formação de um diagnóstico, e este uso trouxe um imenso alívio para um sofrimento atroz, e sua não utilização teria sido uma desconsideração pela intensidade do sofrimento alheio.

Tomoaliberdade de trazer otestemunhode "Asdrúbal", que me contava viver recriminações terríveis, por vozes que Ihe atacavam a cabeça, Ihe invadiam o pensamento quase todo o tempo, com insultos e humilhações.

E diante do uso do potente antipsicótico haloperidol, me conta que este medicamento é "anticoncepcional", porque com ele não consegue conceber mais nada, e eram muitas suas invenções mirabolantes, mas que o mesmo Ihe trouxe um descanso tamanho de seu sofrimento, que recusa as minhas tentativas de redução da dose, tentativas que atribui ao meu desconhecimento da intensidade do que acontecia com ele.

Mas, por outro lado, para lembrar a pertinência das críticas apresentadas por Michel Foucault, retomo alguns casos clínicos que me parecem representativos da situação lastimável que muitas vezes envolve a clínica psiquiátrica.

Para tanto, a título de exemplo, reproduzo casos clínicos descritos por Pinel, portanto, no alvorecer da psiquiatria, e dois casos clínicos descritos por Glen $\mathrm{O}$. Gabbard (2009), sendo representante, portanto, de uma forma clínica atual, como formulada e praticada em uma dinâmica americana; tributária, portanto, do que poderíamos considerar, com as devidas ressalvas, de uma 
visão científica americana de mundo. Passemos aos casos.

Inicio com alguns casos descritos no tratado MédicoFilosófico Sobre a Alienação Mental ou a Mania, De Philipe Pinel (2007), primeiramente com um conjunto de comentários rápidos sobre inúmeros casos, reunidos sob o surpreendente título que parece uma verdadeira ironia mórbida:

"Todos os maníacos são igualmente capazes de suportar os graus extremos de fome e frio?"251

Como se pode acompanhar a seguir ao longo dos comentários de Pinel, o trecho constitui exemplo do exercício disciplinar, com sua coação física, mas também com indícios do funcionamento da racionalidade dos riscos e da segurança:

"Uma das características notáveis da excitação nervosa própria à maior parte dos acessos de mania é a de levar ao mais alto grau a força muscular e de fazer suportar com impunidade os extremos da fome e do frio rigoroso; verdades já conhecidas, mas muito genericamente aplicadas a toda espécie de mania e a todos seus períodos. Vi exemplos de desenvolvimento prodigioso de forças musculares, pois as amarras mais fortes cediam aos esforços do maníaco com facilidade surpreendente, considerandose o grau de resistência vencido. Quantas vezes o insano torna-se ainda mais temível, se os seus membros estiverem livres, pela forte impressão que ele adquire quanto à sua superioridade? Mas esta energia da contração muscular está longe de ser notada em alguns acessos periódicos, em que se sobressai um estado de estupor, também ${ }^{251}$ Pinel, 2007, p. 89. não se encontrando muito, em geral, nos 
intervalos dos acessos. Não se tem menos que desconfiar das proposições muito genéricas sobre a facilidade que apresentam os alienados de suportar a fome mais extrema, já que alguns acessos, ao contrário, são marcados por uma voracidade singular, e nos quais o desfalecimento segue-se prontamente à redução da alimentação. Falase de um hospital de Nápoles em que uma dieta rígida e própria a extenuar o alienado é um dos fundamentos do tratamento. Seria difícil remontar à origem deste princípio singular ou antes, desse preconceito destruidor. Uma mal-sucedida experiência, que foi consequência dos recentes tempos de miséria, não ensinou a Bicêtre senão que a falha da alimentação serve unicamente a exasperar e a prolongar a mania, quando não chega mesmo a torná-la mortal. Por outro lado, um dos sintomas mais perigosos e que se deve temer durante alguns acessos é a recusa obstinada de toda comida, recusa que vi algumas vezes prolongar-se por quatro, sete ou mesmo quinze dias seguidos, sem perda da vida, visto que era fornecida uma bebida abundante e freqüente. Que meios morais, que expediente não são precisos então empregar para triunfar contra essa obstinação cega! A constância e a facilidade com a qual alguns insanos suportam o frio mais rigoroso e prolongado parece supor um grau singular de intensidade no seu calor animal, e que seria interessante registrar no termômetro, se a experiência fosse possível em outro momento que não o da calma. No mês de nivoso do ano III, e durante alguns dias em que o termômetro indicava 10, 11 e até 16 graus negativos, um alienado não conseguia manter seu cobertor de lã, ficando sentado no chão de sua cela vestindo somente uma camisa; pela manhã, quando 
se abria sua porta, ele saia correndo pelo interior do hospício, pegava um punhado de neve ou de gelo para jogá-los contra seu peito com uma espécie de deleite, como se respira ar fresco durante a canícula. Mas, por outro lado, quantos insanos são vivamente afetados pelo frio, mesmo durante seus acessos? Com que rapidez geral não os vemos precipitaremse no inverno sob suas cobertas quentes? $\mathrm{E}$ não acontecem acidentes, a cada ano, pelo congelamento dos pés ou das mãos, quando a estação é muito rigorosa?"252

Vejamos agora propriamente uma descrição de um caso clínico, intitulado: "Feliz expediente empregado para a cura de um maníaco":

"Um dos mais famosos relojoeiros de Paris apaixona-se pela quimera do movimento perpétuo e, para aí chegar, entrega-se ao trabalho com ardor infatigável; a seguir, ocorrem a perda de sono, a exaltação progressiva da imaginação e, dentre em pouco, um verdadeiro delírio, em função dos terrores renascentes que os tumultos da revolução excitavam. A derrocada da sua razão é marcada por uma singularidade particular. Ele acreditava que sua cabeça tinha caído sobre o patíbulo, e que fora colocada misturada a cabeças de várias outras vítimas, e que os juízes, por um arrependimento tardio de sua sentença cruel, teriam ordenado resgatar essas cabeças e recolocálas em seus corpos respectivos; mas que, por uma espécie de descaso, teria sido colocada sobre seus ombros a cabeça de um de seus colegas de infortúnio. Essa ideia da troca de sua cabeça ocupa-o dia e noite, fazendo com que seus pais se decidam a submetê-lo ao tratamento dos maníacos no Hôtel-Dieu; e

${ }^{252}$ Pinel, 2007, p. 89-90. 
ele foi em seguida transferido ao hospício dos alienados de Bicêtre. Então, nada se igualava à sua extravagência e às ardentes explosões de seu humor jovial; ele canta, grita, dança; e como sua mania não o levava a atos de violência, deixava-se que errasse livremente pelo hospício, a fim de que este efervescente alvoroço se dissipasse. "Vejam meus dentes - repetia ele sem parar -, eu os tinha muito bonitos e eis que agora estão podres; minha boca era são, agora infecta. Que diferença entre esses cabelos e os que eu tinha antes da troca de cabeça!" O mais violento acesso e furor sucede, enfim, a essa jocosidade delirante: segue-se uma rígida reclusão em sua cela, com violentos transportes de cólera e um instinto destruidor que o faz deixar tudo em pedaços. Com a proximidade do inverno, seus transportes coléricos se apaziguam e, ainda que sempre extravagante em suas ideias, não é mais perigoso, restituindo-seIhe então a liberdade no interior do hospício. A ideia do movimento perpétuo renovase em meio às suas divagações insanas; ele rabisca sem parar as paredes e as portas com desenhos do mecanismo adequado para operá-lo. Como arrancá-lo desta quimera senão mostrando a inutilidade de seus múltiplos esforços e por uma espécie de saciedade? Comprometemos os pais a enviar-lhe alguns utensílios de relojoaria, com objetos próprios ao trabalho, como lâminas de cobre e de aço, correias de relógios, etc. $\mathrm{O}$ vigilante do hospício fez mais: permitiuIhe que fizesse um tipo de ateliê à frente de seus quarto, para lá trabalhar à vontade; trabalha então com ardor e zelo redobrados, concentrando ali toda sua atenção, a ponto de esquecer-se das horas de suas refeições. Após aproximadamente um mês de trabalho, mantido com constância e digno dos melhores 
sucessos, nosso artista acredita ter seguido um caminho errado; desmonta todo o seu mecanismo novo, recomeçando com um outro plano; mais quinze dias de aplicação; articula então todas as suas peças, acreditando ter ali um ajuste perfeito, ainda melhor por dele resultar um movimento contínuo que ele julga próprio à auto-reprodução. A partir de então, mostra alegria exaltada e uma espécie de triunfo. Corre então com apressados passos pelo o interior do hospício, gritando como um outro Arquimedes: "Eis enfim este célebre problema resolvido, este que fora obstáculo dos homens mais hábeis!". Mas um incidente o desconcerta em meio à sua marcha triunfante. Os maquinismos cessam e o pretendido movimento perpétuo não dura senão alguns minutos. A confusão sucede-se à embriaguez da alegria; mas, para salvar seu amor próprio de uma confissão humilhante declara poder facilmente vencer o obstáculo e que, no entanto, cansado de suas tentativas, não deseja mais ocupar-se com trabalhos de relojoaria. Restava ainda uma ideia delirante para ser combatida e destruída: era a da sua pretensa mudança de cabeça, que aliás renovava-se no meio de seus trabalhos. Uma brincadeira inteligente e sem réplica pareceu adequada para corrigilo. Combina-se com outro convalescente, muito engraçado e de humor jovial, o papel que ele tinha a desempenhar, e arma-se uma conversa entre o doente e o nosso artista; este traz habilmente à baila o famoso milagre de São Denis, o qual, caminhando levava sua cabeça entre mãos, dando-lhe beijos incessantes. O relojoeiro sustenta fortemente a possibilidade do fato e procura confirmálo por seu próprio exemplo. Seu interlocutor dá então uma risada estrondosa, replicandoIhe em tom zombeteiro: "Que insano és 
tu! Como São Denis teria podido beijar sua testa? Teria sido com seu calcanhar?". Essa réplica inesperada e sem resposta toca vivamente o alienado, fazendo com que ele se retire confuso em meio aos risos que lhe dirigem, e não falou mais sobre sua troca de cabeça. A séria ocupação com os trabalhos de relojoaria, continuada durante alguns meses, restitui-Ihe a razão. Ele foi restituído à família e há mais de cinco anos exerce sua profissão, sem experimentar recaídas." 253

Faço questão de reproduzir alguns poucos casos aqui, mantendo integralmente o texto, até porque, muitas vezes, lendo comentários ou críticas de autores como Michel Foucault, a propósito dos tratamentos dos primeiros psiquiatras, por vezes pensava que não deveria ser possível que os tratamentos fossem realmente de tal maneira.

Reproduzo ainda um último caso de Pinel, que apenas repete um mesmo modo operante, trata-se da "História de um alienado muito violento e curado por uma repressão sábia e enérgica":

"No tratamento moral - dizem os redatores da Biblioteca Britânica - não se consideram os loucos como absolutamente privados de razão, isto é, como inacessíveis aos motivos de temor, de esperança, de sentimentos de honra... É preciso subjugá-los antes, encorajando-os a seguir.' Essas proposições gerais são certamente muito verdadeiras e fecundas em aplicações úteis; mas, para sentilas vivamente, são necessários exemplos, e é neste ponto que os ingleses mantêm silêncio. Ainda uma história dessa natureza acrescida às precedentes, e ficaremos mais convencidos de que este segredo é conhecido na França: um pai de família, muito recomendável,

${ }_{253}$ Pinel, 2007, p. 114-115. 
perde sua fortuna e quase todos os recursos em função dos acontecimentos da revolução, e uma tristeza profunda o conduz logo a um estado maníaco. Recebe tratamento rotineiro e comum da mania por meio dos banhos de imersão, das duchas, das sangrias repetidas e dos meios de repressão mais desumanos; os sintomas, longe de ceder, pioram, fazendo com que fosse transferido para Bicêtre, como incurável. O vigilante, sem paralisar-se frente aos avisos que lhe davam informando que o alienado é muito perigoso, entrega-o um pouco a ele mesmo, para estudar seu caráter. Nunca um alienado havia dado curso mais livre a seus atos de extravagância: volta-se a si inflado de orgulho, acredita ser o profeta Maomé, golpeia todos que se encontram em sua passagem, ordenando-lhes que se prostrem e lhe prestem homenagem. Passa o dia todo pronunciando supostas sentenças de proscrição e de morte: não são senão ameaças, proposições ultrajantes contra as pessoas de serviço; a autoridade do vigilante é desdenhada e desconhecida. Um dia em que sua esposa implora para visitá-lo voltase contra ela, e talvez teria lhe batido se não fosse a assistência imediata em seu socorro. O que poderiam produzir as vias de brandura e as mais moderadas advertências sobre um alienado que olhava os outros homens como átomos de poeira? Intima-se-lhe que fique tranqüilo $e$, frente a sua recusa em obedecer, é punido com colete de força e com reclusão de uma hora, para lhe fazer sentir sua dependência. $O$ vigilante logo o retira de sua cela, falando-lhe em um tom amigável, reprime-o quanto à sua desobediência, expressando-lhe o quanto lamenta ter sido forçado a usar com ele medidas rigorosas. Dá-se o retorno de seus transtornos insensatos no dia seguinte, seguidos pelos 
mesmos meios de repressão; e pelas mesmas promessas ilusórias de ser mais tranqüilo no futuro. Nova e terceira recaída, seguida, como punição, de um dia inteiro de detenção, e de calma mais marcada nos dias seguintes. Uma explosão, pela quarta vez, de seu humor altivo e turbulento, fez sentir ao vigilante a necessidade de produzir sobre este alienado uma impressão durável e profunda. Ele o interpela com veemência, procura fazer com que abandone toda esperança de reconciliação, e prendê-lo faz bruscamente, declarando que seria, a partir de então, inexorável. Dois dias se passam e, durante sua ronda, o vigilante não responde senão por um riso irônico às instâncias reiteradas que o alienado lhe fazia. Mas, por um acordo entre o vigilante e sua esposa, esta entrega a liberdade ao detento ao fim do terceiro dia, recomendando-lhe expressamente que contenha seus transtornos furiosos, e que não a exponha a recriminações por ter sido indulgente demais com ele. $\mathrm{O}$ alienado parece calmo durante vários dias e, nos momentos em que ele apenas pode conter seus desvarios delirantes, um único olhar da vigilante é suficiente para trazê-lo de volta à ordem, e ele logo corre à sua cela, por medo de incorrer em falta. Esses combates interiores, frequentemente repetidos, entre o retorno automático dos desvarios maníacos e o temor de uma detenção indefinida o habituam cada vez mais a dominar sua vontade e a se administrar. Ele sente-se, aliás, penetrado de afeição e de estima por aqueles que a ele se dirigiam com tanta consideração e condescendência, e foi dessa forma que todos os antigos traços de sua mania foram pouco a pouco dissipados; depois, seis meses de prova são suficientes para alcançar a cura completa, e este respeitável pai de família 
ocupa-se agora, com atividade infatigável, em reparar sua fortuna."254

Pode-se obstar, todavia, que estes relatos, que apresentam uma visão ingênua ou simplista diante dos transtornos mentais, são do ano de 1800, de um período no qual a ciência psiquiátrica ainda engatinhava, e que não apresentam absolutamente nada em comum com a psiquiatria atual, contemporânea. Vejamos então alguns casos clínicos publicados em livro atual, de reconhecida importância e confiabilidade pelos meios psiquiátricos.

Trata-se de dois casos clínicos, dentre bem poucos que são apresentados por Glen O. Gabbard, apesar das 910 páginas de seu livro "Tratamento dos Transtornos Psiquiátricos":

"A Sra. Cera uma mulher destra de 58 anos que tinha uma longa história de depressão maior recorrente. Após diversos testes malsucedidos com vários medicamentos antidepressivos, usados isoladamente e em combinação, seus três episódios anteriores haviam levado a encaminhamentos para ECT bilateral. Esses tratamentos foram bem-tolerados e associados a uma melhora notável, com exceção de um comprometimento moderado e transitório da memória. Depois de cada curso de ECT, com o último terminando cinco meses atrás, ela recebeu farmacoterapia de continuação e apenas teve benefícios transitórios. Não foram observados riscos médicos na avaliação pré-ECT durante os últimos três episódios.

Devidoà sua história recentede boas respostas, exceto pela perturbação da memória com ${ }^{254}$ Pinel, 2007, p. 136-138. 
ECT prévia, a sra. C foi encaminhada a um tratamento com aplicações de ECT unilateral direita para reduzir o risco de morbidade cognitiva cumulativa. Contudo, foi observada pouca resposta terapêutica após a sexta aplicação, ao contrário do que havia sido observado em seus tratamentos anteriores com ECT bilateral. Após uma discussão com a sra. C e seu marido, foi feita mudança para ECT bilateral e ela começou a apresentar melhoras depois de duas aplicações. Durante a décima aplicação, foi observado que a duração das convulsões havia caído para 22 segundos, apesar de ser usada estimulação elétrica máxima. A partir da décima primeira aplicação, seu agente anestésico foi trocado de metoexital para cetamina, levando a um aumento de $100 \%$ na duração das convulsões. A sra. C continuou a melhorar e alcançou um platô terapêutico após 13 aplicações.

Em consequência de sua história de recaídas rápidas, a sra. $\mathrm{C}$ foi encaminhada a ECT $\mathrm{C} / \mathrm{M}$, para a qual forneceu $\mathrm{O}$ consentimento necessário. As aplicações iniciaram com freqüência de uma por semana durante as primeiras quatro semanas, seguidas de uma a cada duas semanas por quatro semanas, uma a cada três semanas pelas próximas seis semanas e mensalmente depois disso. Durante esse período, ela permaneceu em remissão clínica sem ter efeitos adversos. Após 12 meses em ECT C/M, as aplicações foram interrompidas, sendo mantido um acompanhamento minucioso. Em sua consulta mais recente, 18 meses após o último tratamento, a sra. C permanecia sem usar medicamentos psicotrópicos e se mantinha eutímica." 255

O que acontece neste tratamento? O que opera aí?

${ }^{255}$ Gabbard, 2009, p. 446. 
Mesmo com as devidas ressalvas de que esta descrição é apenas uma vinheta clínica, e não tem a intenção de descrever o tratamento, ainda assim, é impossível não ver aí uma tecnociência que simplesmente parece desconhecer ou desconsiderar a trajetória de vida da pessoa em questão, restringindo-se e centrando-se em procedimentos técnicos, seus possíveis resultados e prováveis efeitos colaterais.

Vejamos ainda outro exemplo:

“Carlos tinha 14 anos e Q.I de 122. Morava com sua mãe e com uma irmã mais velha em um contexto de classe média baixa. Seu pai tinha morrido depois de uma longa doença quando ele estava com 9 anos. Carlos tinha histórico de comportamento de identificação com o sexo oposto desde a infância (p. ex., afiliação com um grupo feminino, travestismo) e de evitação de brincadeiras mais brutas e esportes coletivos. Retrospectivamente, não pareceu que ele tivesse diagnóstico formal para TIG. Assim que entrou na adolescência, seu grupo de relações se tornou mais problemático. Ele ficou consciente de sentimentos sexuais por outros meninos, e suas antigas amigas tornaram-se menos interessadas em socializar com ele, uma vez que estavam agora saindo com outros meninos. Carlos alternava entre descrever a si mesmo como "transexual" e "gay". A ideia de que pudesse ser gay era muito sofrida para ele e manteve o pensamento de que, se mudasse de sexo, seria normal, porque sua orientação sexual seria, então heterossexual. Sua mãe concordou com a ideia de mudança de sexo porque, conforme sua visão religiosa, a homossexualidade era contra a 'vontade de Deus'."256

Este caso relembra algumas considerações feitas por

${ }^{256}$ Gabbard, 2009, p. 668. 
Foucault a propósito de uma invasão dos assuntos da vida pela psiquiatria, uma psiquiatrização da vida, no movimento que leva a psiquiatria do campo da doença mental para o campo da normalização da vida, que se dá por inúmeras vias, mas com privilégio de duas, pela via da psiquiatrização da infância, e pela via da sexualidade, como descrito mais detidamente por Foucault nos cursos "Os Anormais"257, e "O Poder Psiquiátrico"258, repetidamente referidos acima. Ou ainda, psiquiatrização das duas, infância e sexualidade concomitantemente, como neste último caso clínico.

É preciso ressaltar que não procurei escolher alguns casos especialmente criticáveis; e que, ao contrário, quando os casos clínicos, cada vez mais raros, aparecem nos tratados psiquiátricos, são exatamente nestes termos, daí me permito restringir as descrições clínicas a apenas estas, entendendo que a inclusão de outros exemplos dos casos clínicos publicados nos moldes da psiquiatria tradicional, seria redundante.

Porém, é preciso retomar uma indispensável ressalva. É que, ao apresentar estes pouquíssimos casos, ainda que bastante representativos da literatura psiquiátrica, passada e presente, não tenho a pretensão de fazer uma crítica totalizante, a respeito das inumeráveis práticas psiquiátricas.

Com isto quero dizer, em primeiro lugar, que acontecem inúmeras práticas psiquiátricas que são muito mais interessantes do que o que aparece nestes poucos casos clínicos.

Poderia dizer até que, a multiplicidade de práticas psiquiátricas é equivalente à multiplicidade de psiquiatras, pois cada profissional acaba desenvolvendo uma forma peculiar de arregimentar o conjunto de ferramentas que a 257 Foucault, 2001. ${ }^{258}$ Foucault, 2006. 
psiquiatria coloca à disposição.

É, além disto, além da forma peculiar como usa as ferramentas psiquiátricas, o próprio psiquiatra que entra em jogo na prática psiquiátrica. É também as inúmeras outras ferramentas que o profissional agrega às próprias da psiquiatria, em interação com os usuários, que vai sublinhando assim, a multiplicidade de formas de se exercer a psiquiatria.

Contudo, os exemplos valem bem aqui, sobretudo considerando os propósitos deste estudo, para demonstrar que, valendo-se apenas das ferramentas que a psiquiatria disponibiliza, e utilizando-as de forma técnica, buscando uma "frieza científica", o que se pode construir é justamente uma impossibilidade de se produzir cuidado.

Em todos os exemplos fica bem evidente uma visão técnico-científica, representante de uma estética socrática, racionalista, finalista. Esta visão limita muito as chances de uma linha de fuga, de uma tragicamentalidade estar operando simultaneamente.

Apesar das descrições clínicas psiquiátricas estarem cada vez mais objetivantes, restritivas, centradas em detalhes orgânicos ou biológicos ou psicométricos, como nesta última descrição, que inicia dizendo que o rapaz tinha 14 anos e QI 122; apesar disto, é preciso dizer que estas descrições não fazem justiça às ferramentas operatórias que os saberes psiquiátricos oferecem para as práticas em saúde mental.

Posso por exemplo, recordar aqui a utilidade que se pode obter em inúmeras situações com a utilização desta caixa de ferramentas respeitável e consistente, constituída pela psicopatologia, em sua vertente fenomenológica, desenvolvida, sobretudo por Karl Jaspers. Com inúmeros 
conceitos-ferramenta preciosos, como, a título de exemplo, o de empatia:

"Estas descrições já demonstram que os objetos não eram percebidos apenas com os sentidos. Atribui-se-lhes um caráter afetivo. $\mathrm{O}$ caso mais importante, de se ver no sensível não apenas o sensível, mas de nele se apreender também o psíquico, é a empatia (Einfuehlung) com as outras pessoas. Os fenômenos patológicos residem em fracasso da empatia - os outros parecem mortos, os doentes pensam vê-los apenas externamente, mas já não tem consciência da vida psíquica dos outros - ou em empatia torturantemente insistente - a vida psíquica alheia se impõe com extraordinária vivacidade à passividade sem defesas do enfermo - ou em empatia ilusória, fantástica - percebe-se um psíquico que não é em nada real."259

Jaspers, em sua monumental obra "Psicopatologia Geral", cria uma perspectiva fenomenológica que possa oferecer uma abordagem do homem e seu adoecer:

"Nosso tema é o homem todo em sua enfermidade. Trata-se de enfermidade psíquica ou psiquicamente determinada.

Quem soubesse o que é a alma humana, de que elementos se compõe, quais as forças que, em última instância, a movem, partiria de um projeto da estrutura psíquica. Anteciparia, em suas grandes linhas, o que depois seria elaborado em seus pormenores. Para quem a alma é algo de infinitamente vasto, porém, cuja totalidade não se pode abarcar de maneira alguma, na qual se penetra, investigando por várias vias, para este não haverá nenhum projeto de totalidade. Não conhecemos nenhum conceito

259 Jaspers, s/d, p. 82. 
fundamental que possa conceber o homem exaustivamente. Nenhuma teoria em que se possa apreender, como um acontecimento objetivo, toda a sua realidade."260

Como se pode perceber, temos aqui um posicionamento bem distante de uma prepotência em definir a totalidade do outro, ou até mesmo, de reduzi-lo a sua doença. E ainda:

"O psicopatologista depende do alcance, da abertura e plenitude de sua capacidade de vivenciar e perceber. Há uma grande diferença entre as pessoas que andam cegas de olhos abertos pelo mundo dos doentes e a segurança que a sensibilidade da participação confere a uma percepção clara.

A repercussão na própria alma do que acontece no outro, exige, então, do pesquisador que objetive pelo pensamento suas experiências. Comover-se ainda não é conhecer, mas apenas a fonte das intuições que trazem o material indispensável ao conhecimento. O psicopatologista, que realmente percebe, é uma alma vibrante, que domina constantemente suas experiências, elaborando-as racionalmente." 261

Temos aqui, portanto, uma psicopatologia que, em sua melhor tradição - antes da decadência promovida pelos manuais diagnósticos, que chegaram, na atualidade, ao DSM IV ${ }^{262}$, DSM V e a CID $10^{263}$ - apesar de reconhecer a alma vibrante, faz sua aposta inteiramente na racionalidade dominante, em uma perfeita "estética socrática", como descrita acima.

\footnotetext{
260 Jaspers, s/d, p. 17.

${ }^{261}$ Ibidem, p. 35.

${ }^{262}$ American Psychiatric Association, 1995.

${ }^{263}$ Organização Mundial de Saúde, 1993.
} 
Mas, ainda assim, uma psicopatologia que tenta captar a vivência, ainda que atrelada e submetida à consciência:

"Um dos fenômenos da alma é a vivência. Numa imagem, denomina-se a corrente da consciência, a corrente única de um processo indivisível, que, em inúmeros indivíduos, corre de um modo sempre diverso. O que fazemos dela, quando a conhecemos? Os processos sempre em fluxo se estratificam para nós, numa objetivação fenomenológica, em formas fixas. Falamos de uma percepção falsa, de um afeto, de um pensamento como se possuíssemos com isso determinados objetos, que, assim como os pensamentos, existiriam ao menos por algum tempo. A fenomenologia apresenta estas vivências internas subjetivas dos pacientes, aquilo que existe e ocorre em suas consciências." ${ }^{264}$

Esta obra de Jaspers é repleta de casos clínicos que desenvolvem seus conceitos, vejamos um exemplo:

"Certo casal faz, marido e mulher ao mesmo tempo, um processo esquizofrênico, formando em comum suas imagens delirantes e desenvolvendo com os filhos (normais que são, apenas apresentam-se 'induzidos') um delírio familial de conteúdo comum; donde resulta a prática em comum de certos atos. Todos desenvolvem concepção comum sobre a origem e as fases da perseguição que se acha dirigida contra eles; conversa-se a respeito deles, os jornais trazem alusões ao que fazem, estão mandando gente para espionálos. Há um aparelho que zumbe, lançando nuvens e vapores malcheirosos para dentro de casa, formando figuras e desenhos no teto. O marido tem alucinações mais ópticas; a mulher, mais auditivas; aquele relata roubo de pensamento; a mulher, vivências

${ }^{264}$ Jaspers, s/d, p. 69. 
esquizofrênicas de cativeiro. A coincidência não está na funcionalidade, mas no conteúdo do distúrbio. Os doentes chegam a formar a compreensão de certo conhecimento cósmico comum, pelo qual as peculiaridades das vivências individuais vêm a constituir um todo que lhes é comum: estamos sendo perseguidos, onde quer que estejamos nos perseguem, Daí viverem os doentes, mais os filhos, alienados do mundo; por assim dizer, acometidos em comum. A perseguição, as ameaças não cansam de ampliar-se: as autoridades, o povo em geral, os católicos etc., todos agem contra eles; as perseguições não vem de um lado só, mas de toda a parte, do mundo inteiro que os cerca, de perto e de longe; perseguições que se caracterizam pelo fato de os perseguidores serem secretos, encobertos. As alusões dissimuladas, o escárnio que se ouviu ao passar, o que se diz, controlando-os e criticando-os, avoluma-se cada vez mais. Um mundo hostil envolve os doentes, que o entendem comunitariamente sempre em renovação, a partir de vivências sempre novas; daí, a prática em comum de certos atos, como medida de defesa contra os 'aparelhos', alterações na estrutura da casa, planos para descobrir os perseguidores etc.; o que tudo termina na internação do casal." ${ }^{265}$

Como se vê, também aqui, na psicopatologia fenomenológica, ferramenta que pode ser de grande utilidade em dadas ocasiões, se conduzida como recurso compreensivo absoluto, gera uma racionalização que não propicia aberturas para produzir cuidado, não incentiva o encontro franco entre trabalhador e usuário, ainda que se fundamente, teoricamente, na empatia.

Também os saberes da psicofarmacologia, e, logicamente, seus psicofármacos, apresentam utilidade e 265 Jaspers, s/d, p. 343. 
validade imensa, em variadas circunstâncias, constituindo uma caixa de ferramentas das mais importantes, apesar de freqüentemente hipertrofiada, supervalorizada, e que não cessa de crescer.

Um grande risco da predominância da psicofarmacologia na clínica psiquiátrica é o reducionismo do adoecer psíquico ao orgânico, à neuroquímica, ao neurobiológico, à neurotransmissão, com suas sinapses, dendritos, axônios, enzimas, receptores, membranas e trans-membranas:

"A psicofarmacologia moderna é em grande parte a história da neurotransmissão química. Para entender as ações das drogas no cérebro, compreender o impacto das doenças sobre o sistema nervoso central (SNC) e interpretar as conseqüências comportamentais dos medicamentos utilizados em psiquiatria, deve-se ter fluência na linguagem e nos princípios da neurotransmissão química."266

Ou ainda, com este mesmo autor, referência inquestionável em psicofarmacologia:

"A psicose possivelmente apresenta algumas
analogias com a crise convulsiva, uma vez
que a transmissão excessiva de dopamina nas
áreas mesolímbicas do cérebro pode levar
a sintomas tais como delírios, alucinações
e distúrbios do pensamento em vários
transtornos psiquiátricos." ${ }^{267}$

Apesar de, em geral, neste e em outros livros de psicofarmacologia não encontrarmos casos clínicos propriamente ditos, as referências sumariamente aos critérios diagnósticos dos manuais como o DSM-IV, e as indicações de algum manejo dos pacientes, deixa perceber ${ }^{266}$ Sthal, 1998, p. 1.

267 Ibidem, p. 103. 
a rigidez deste contato, conduzido por uma racionalidade absolutamente pragmática, onde cabe ao usuário aprender para concordar:

"A eficiência de qualquer tratamento depende do esforço cooperativo do paciente e do médico.

O paciente deve ter conhecimento de seu diagnóstico, prognóstico e opções de tratamento, incluindo custos, duração e efeitos colaterais potenciais. Na realização da abordagem educativa do paciente $\mathrm{e}$ sua família acerca do tratamento clínico da depressão, é útil enfatizar as seguintes informações: (...)." ${ }^{\prime 268}$

É oportuno relembrar que este estudo não tem a pretensão de produzir uma avaliação da utilidade ou não dos procedimentos psiquiátricos, de suas ferramentas conceituais ou práticas; ou de realizar (de novo?) as críticas de suas posições excessivamente biologizantes, etc.

A que me propus aqui, foi submeter essas situações clínicas, ao crivo da tragicamentalidade, considerando para tanto, a governamentalidade e a produção do cuidado.

Neste aspecto, não é difícil afirmar a possibilidade remota de se perceber produção de cuidado, como um excedente da clínica, como um acontecimento fruto de um encontro intercessor ${ }^{269}$ entre usuário e trabalhador, nos casos clínicos relatados por Pinel, por Gabbard, por Jaspers, e nas recomendações de Stahl.

Temos nestes casos apresentados uma visão que se encontra inteiramente sob a ótica ciclópica de um socratismo absolutamente racionalizante, que impera, sem 268 Sthal, 1998, p. 118.

269 Deleuze, 2007, p. 156. Deleuze expõe a produção de potência a partir dos intercessores: "o essencial são os intercessores 
a possbilidade de surgir um cuidado e, por conseguinte, sem muito espaço para o exercício de uma tragicamentalidade.

O que não quer dizer, volto a esta ressalva, que isto não ocorra, ou não possa ocorrer em inúmeras práticas psiquiátricas. O que posso apontar, a partir dos casos apresentados, é como esta estrutura discursiva não é facilitadora, não é promovedora das possibilidades de uma tragicamentalidade.

Passo então, para uma tentativa de abordagem da clínica psicanalítica.

\section{Clínica Psicanalítica}

A primeira dificuldade para a abordagem de uma clínica psicanalítica é: qual clínica psicanalítica? Pois existe uma variedade de psicanálises, com várias particularidades técnicas e até divergências intensas em suas clínicas.

Em segundo lugar, o comentário que fiz, de que na verdade talvez haja tantas psiquiatrias quantos psiquiatras houver, é ainda mais pertinente no que se refere à psicanálise, pois seu exercício envolve também a análise pessoal do analista.

Em terceiro lugar, certamente não apresento aqui uma análise exaustiva da psicanálise, ou de sua técnica clínica, mas antes, pretendo apenas, apresentá-la em linhas gerais, para aplicar ao seu funcionamento esta dupla conceitual analisadora, a governamentalidade e a tragicamentalidade.

Se para representar a clínica psiquiátrica recorri a casos clínicos relatados por Pinel, faço agora, de forma equivalente, uma apresentação de casos clínicos de Sigmund Freud. 
Contudo, a extensão da descrição clínica dos casos freudianos inviabiliza a reprodução de seu texto integral aqui, pois cada um deles é um verdadeiro livro em si.

Farei então alguns comentários, com citações de trechos apenas, dos cinco principais casos clínicos publicados por Freud, que permitam uma visão geral dos casos, como abordados pelo pai da psicanálise.

\section{Dora}

Começo, portanto, abordando o texto "Fragmento da análise de um caso de Histeria", de 1905 [1901], o "Caso Dora", primeiro caso clínico publicado após a fase considerada pré-psicanalítica dos "Estudos sobre Histeria".

E neste caso, Freud indica que sua técnica de análise mudou enormemente desde aqueles "Estudos Sobre Histeria", e tal mudança consiste em que:

"Naquela época, o trabalho [de análise] partia dos sintomas e visava esclarecê-los um após o outro. Desde então, abandonei essa técnica por achá-la totalmente inadequada para lidar com a estrutura mais fina da neurose. Agora deixo que o próprio paciente determine o tema do trabalho cotidiano, e assim parto da superfície que seu inconsciente ofereça a sua atenção naquele momento. Mas desse modo, tudo o que se relaciona com a solução de determinado sintoma emerge em fragmentos, entremeado com vários contextos e distribuíd o por épocas amplamente dispersas. Apesar dessa aparente desvantagem, a nova técnica é muito superior à antiga, e é incontestavelmente a única possível."270

${ }^{270}$ Freud, 1989 [1901-1905], p. 20-21. 
Temos neste ponto a declaração de Freud do abandono de uma condução sistemática a partir do sintoma, centrado no sintoma, para a técnica da associação livre, certamente se desvencilhando de um hábito ou de um vício comum à clínica em geral, de conduzir a entrevista ou o diálogo, uma técnica de anamnese. Bem, Freud está, neste tratamento, rompendo com a longa tradição da anamnese, permitindo ao paciente a livre associação, que representa, na perspectiva que nos interessa aqui, certamente uma grande abertura para a possibilidade de encontros imprevisíveis, para o acontecimento do cuidado.

Mas logo em seguida, Freud refere-se a uma supressão, neste seu relato clínico, do "trabalho interpretativo a que as associações e comunicações da paciente tiveram de ser submetidas, expondo apenas seus resultados."271

Com isto, perdemos a oportunidade de acompanhar, de perto, o processo interpretativo, mas podemos perceber aí, nesta interpretação à qual deve ser submetida a palavra da paciente, um dos pontos críticos de criação de barreiras ao processo intercessor (descrito acima).

Freud aponta ainda, que a análise foi interrompida após curtos três meses, e não atingiu o ponto que ele esperava:

"o tratamento não prosseguiu até alcançar a meta prevista, tendo sido interrompido por vontade da própria paciente depois de chegar a certo ponto. Nessa ocasião, alguns dos enigmas do caso não tinham sequer sido abordados, e outros se haviam esclarecido de maneira incompleta, ao passo que, se o trabalho tivesse prosseguido, teríamos sem dúvida avançado em todos os pontos até o mais completo esclarecimento possível.".272

271 Freud, 1989 [1901-1905], p. 21.

272 Ibidem, p. 20. 
Temos então que a meta a ser alcançada é o mais completo esclarecimento possível de todos os pontos, um projeto interpretativo de solucionar enigmas, esclarecendo pontos obscuros. Mais adiante, Freud dirá que o objetivo do tratamento é eliminar os sintomas, substituí-los por pensamentos conscientes, reparar a memória do paciente.

Ainda nos preliminares do caso, Freud aponta que:

"justamente a parte mais difícil do trabalho
técnico nunca entrou em jogo com essa
paciente, pois o fator da 'transferência',
considerado no final do caso clínico (p.110
e ss.), não foi abordado durante o curto
tratamento."273

Ora, é justamente este fator, a transferência, que pode permitir uma conexão bastante interessante, com 0 que estamos chamando aqui de encontro intercessor.

Logo no início da descrição clínica, Freud admite que este seu caso Dora é, sobretudo, uma demonstração da utilidade da "interpretação dos sonhos", método que havia divulgado alguns anos antes, em 1900, e que estaria agora sendo constatado por este exemplo:

"Com esta publicação tão incompleta, eu quis alcançar duas coisas. Em primeiro lugar, como um complemento a meu livro sobre a interpretação dos sonhos, mostrar como essa arte, que de outro modo seria inútil, pode ser proveitosa para a descoberta do oculto e do recalcado na vida anímica; (...)."274

Freud, por um lado, afasta-se do sintoma da clínica tradicional das doenças nervosas, que possui significado intrínseco, relativo apenas como relacionado a um grupo de outros sintomas que definirão o quadro mórbido, mas

273 Freud, 1989 [1901-1905], p. 21.

${ }^{274}$ Ibidem, p. 108. 
sempre um fim em si mesmo. Estabelece em contrapartida o sintoma freudiano que possui um significado "emprestado", que em cada caso é diferente segundo a natureza dos pensamentos reprimidos. O sintoma freudiano não é um fim em si mesmo, é um meio de expressão escolhido com base nas relações entre os pensamentos inconscientes, podendo se conhecer, a priori, apenas algumas formas típicas de como estas relações geralmente ocorrem.

Se o sintoma na clínica tradicional era encarado como um fato em si mesmo, e falava-se em esclarecimento de um sintoma apenas no sentido de que ele aponta para a possibilidade de que outros sintomas estejam ocorrendo, caracterizando uma patologia determinada; já na clínica freudiana, o esclarecimento dos sintomas é alcançado buscando-se sua significação psíquica.

Isto abre uma possibilidade imensa de diálogos, de encontros entre o terapeuta e o paciente. Mas, por outro lado, o que podemos constatar neste relato clínico é que, ao mesmo tempo que faz este movimento de abertura, Freud parece aprisionar os sintomas em uma nova grade interpretativa.

Certamente os sintomas não são mais referidos a entidades nosológicas pré-estabelecidas pela clínica psiquiátrica, como por exemplo, quando se diz que uma vivência delirante pode significar que trata-se de um caso de paranóia, por exemplo. Mas, agora, são referidos a modelos explicativos, que, pelo menos neste relato clínico, se vêem plenamente confirmados.

Ou seja, o caso Dora confirma, através das interpretações de Freud, o que este já havia postulado antes, que:

“O sonho não é um propósito que se representa como executado, mas um 
desejo que se representa como realizado e precisamente, além disso, um desejo proveniente da vida infantil.".275

E que:

"Chamo de atos sintomáticos as funções que as pessoas executam, como se costuma dizer, de maneira automática e inconsciente, sem reparar nelas, como que brincando, querendo negar-lhes qualquer significação e, se inquiridas, explicando-as como indiferentes e casuais." 276

E ainda, que:

"Esse amor pelo pai, portanto, fora recentemente reavivado e, sendo esse o caso, podemos perguntar-nos com que finalidade isso ocorreu. Obviamente, como sintoma reativo para suprimir alguma outra coisa que, por conseguinte, ainda era poderosa no inconsciente." 277

E que:

"Aprendi a ver nessas relações amorosas inconscientes entre pai e filha ou entre mãe e filho, conhecidas por suas conseqüências anormais, uma reivindicação de germes infantis. Expus em outros lugares em que tenra idade a atração sexual se faz sentir entre pais e filhos, e mostrei que a lenda de Édipo provavelmente deve ser considerada como a elaboração poética do que há de típico nessas relações." 278

E ainda:

275 Freud, 1989 [1901-1905], p. 85.

276 Ibidem, p. 77.

277 Ibidem, p. 60.

${ }^{278}$ Ibidem, p. 59. 
"Todos os psiconeuróticos são pessoas de inclinações perversas fortemente acentuadas, mas recalcadas e tornadas inconscientes no curso de seu desenvolvimento." 279

E também:

"Desde então tenho visto inúmeros casos de histeria, ocupando-me de cada um por vários dias, semanas ou anos, e em nenhum deles deixei de descobrir as condições psíquicas postuladas nos Estudos, ou seja, o trauma psíquico, o conflito dos afetos e, como acrescentei em publicações posteriores, a comoção na esfera sexual."280

E, portanto:

"Quem tem olhos para ver e ouvidos para ouvir fica convencido de que os mortais não conseguem guardar nenhum segredo. Aqueles cujos lábios calam denunciam-se com as pontas dos dedos; a denúncia lhe sai por todos os poros. Por isso, a tarefa de tornar consciente o que há de mais secreto no anímico é perfeitamente exeqüível."281

E por fim:

"Empenhava-me também em mostrar que a sexualidade não intervém simplesmente como um deus ex machina que se apresentasse uma única vez em algum ponto da engrenagem dos processos característicos da histeria, mas que fornece a força impulsora para cada sintoma singular e para cada manifestação singular de um sintoma. Os fenômenos patológicos são, dito de maneira franca, a atividade sexual do doente." 282

${ }^{279}$ Freud, 1989 [1901-1905], p. 54.

$280 \mathrm{Ibidem}, \mathrm{p} .31$.

${ }^{281} \mathrm{Ibidem}, \mathrm{p} .78$.

${ }^{282}$ Ibidem, p. 109. 
$\mathrm{O}$ que estou procurando salientar, como de interesse para este estudo, não é, em absoluto, se os pressupostos freudianos estão plenamente corretos, ou até que ponto o pansexualismo freudiano excede a realidade dos fatos, ou, se de fato, os sonhos funcionam pelos mecanismos de condensação, deslocamento e compromisso entre correntes opostas, ou ainda, se de fato, os sintomas histéricos só se apresentam quando as crianças param de se masturbar.

O que estou colocando em relevo, como de particular interesse aqui é que, Freud, ao encontrar em Dora uma masturbadora recalcada, com desejos inconscientes pelo seu pai, pelo Sr. K., pela Sra. K., com fantasias de ser deflorada, ou de ser desposada, com seu fundo polimorfo perverso infantil, não encontra absolutamente nada de novo.

Este é o ponto relevante aqui, que pode sinalizar para um movimento clínico que, apesar de sua fabulosa abertura para o funcionamento inconsciente da mente humana, acaba, neste caso em questão, não gerando um acontecimento que pudesse ter efeitos intercessores em Freud, e parece que também não em Dora, já que interrompeu prematuramente seu tratamento, e parece ter persistido francamente sintomática.

Todavia, é importante lembrar uma ressalva feita por Freud de que, neste caso não se desenvolveu a transferência, ferramenta fundamental de seu trabalho clínico, mais importante que a anterior ferramenta da interpretação.

Vejamos então os casos que se seguiram a este. 


\section{Pequeno Hans:}

Passarei agora ao caso clínico seguinte de Freud, que é, em grande medida, um caso supervisionado por Freud, em que ele indicava as intervenções a serem feitas pelo pai do paciente (Hans). Trata-se do texto "Análise de uma fobia em um menino de cinco anos", de 1909, conhecido como o caso "Pequeno Hans".

Freud já inicia este caso declarando que:

"É verdade que assentei as linhas gerais do tratamento e que numa única ocasião, na qual tive uma conversa com o menino, participei diretamente dele; no entanto, o próprio tratamento foi efetuado pelo pai da criança, sendo a ele que devo meus agradecimentos mais sinceros por me permitir publicar suas observações acerca do caso. Todavia, sua ajuda ultrapassa esta contribuição. Ninguém mais poderia, em minha opinião, ter persuadido a criança a fazer quaisquer declarações como as dela; (...)."283

Temos um caso aqui, portanto, que não foi um caso tratado por Freud, e sim o de uma criança "persuadida" pelo próprio pai a fazer tais declarações.

Se o caso Dora representava uma demonstração do que havia sido postulado na "Interpretação dos Sonhos", neste caso Hans, encontraremos as confirmações acerca da importância da infância na constituição dos variados estados, sejam neuróticos ou outros, e sobretudo, da sexualidade infantil, como Freud havia descrito em seu "Três ensaios sobre a sexualidade".

Confirmando este aspecto, de encontrar nos casos exatamente o que já sabia, Freud declara:

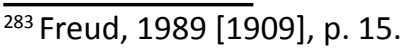


"Falando francamente, não aprendi nada de novo com essa análise, nada que eu já não tivesse sido capaz de descobrir (apesar de muitas vezes menos distintamente e mais indiretamente) em outros pacientes analisados numa idade mais avançada. Mas a neurose desses outros pacientes podia, em todos os casos, ser reportada aos mesmos complexos infantis que foram revelados por trás da fobia de Hans." 284

E o que Freud encontra, ou reencontra neste caso, é um menininho bastante esperto e saudável, sobre o qual seus pais - que eram seguidores de Freud - relatavam com freqüência sobre as descobertas sexuais desta criança, a pedido do próprio Freud, que incluía um vívido interesse pelo órgão sexual, seu e de outras crianças e dos adultos também.

Nesta fase dos três para quatro anos, a mãe inclusive o repreende, por estar manipulando seu próprio pênis, ameaçando-o de que cortaria fora seu pinto se continuasse fazendo isto, de maneira que, muitos meses depois, será reinterpretado como um complexo de castração.

“Contudo, foi essa a ocasião da aquisição do 'complexo de castração', cuja presença vemonos com tanta freqüência obrigados a inferir na análise de neuróticos, ainda que todos eles relutem violentamente em admiti-la."285

Acontece que a partir de aproximadamente quatro anos e meio, este filho de pais psicanalistas, começa a desenvolver uma fobia de cavalos, que gera uma série de constrangimentos e impedimentos na sua circulação social, já que os cavalos eram o meio de transporte geral, estando em toda parte.

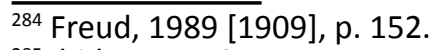

285 Ibidem, p. 18. 
É a partir daí que a análise se desenvolve, conduzida pelo próprio pai, que logo de saída atribui à mãe a piora da criança:

\begin{abstract}
"Sem dúvida, o terreno foi preparado por uma superexcitação sexual devida à ternura da mãe de Hans; mas não sou capaz de especificar a causa real da excitação. Ele receia que um cavalo vá mordê-lo na rua, e esse medo parece estar de alguma forma relacionado com o fato de ele vir-se assustando com um grande pênis." 286
\end{abstract}

A partir desta fobia, neste garoto assustado com um grande pênis, se desenrola uma sistemática investigação feita pelo pai, que não dará muita trégua até o desenlace do processo:

"Hans: 'acho que talvez eu tenha esquecido que ela não tirou as calças.' (e com impaciência:) 'Por favor, me deixe em paz.'"287

E também:

"O pai de Hans estava fazendo perguntas demais, e estava pressionando o inquérito através de suas próprias linhas, em vez de permitir ao garotinho que expressasse seus pensamentos." 288

E o que será encontrado, depois de muito inquérito, por trás desta fobia?

"Hans era realmente um pequeno Édipo que queria ter seu pai 'fora do caminho', queria livrar-se dele, para que pudesse ficar sozinho com sua linda mãe e dormir com ela." 289

\footnotetext{
${ }^{286}$ Freud, 1989 [1909], p. 33.

${ }^{287}$ Ibidem, p. 66.

${ }^{288}$ Ibidem, p. 73.

${ }^{289}$ Ibidem, p. 118.
} 
Claro que o caso não se resume apenas a isto, e o pequeno Hans consegue se sair muito bem, ao contrário de Dora. Primeiro melhora de sua fobia, consegue construir algumas fantasias que Ihe trazem um alívio significativo de sua ansiedade; e, além disso, procura Freud, anos mais tarde, então com dezenove anos, para dizer que está muito bem, apesar da separação dos pais psicanalistas, e que não reconhece em nada como dizendo respeito a si ao ler o caso publicado por Freud.

Este caso clínico, traz à baila, como não poderia deixar de ser, já que a análise é conduzida pelo pai de Hans, a importância que a relação transferencial assume nesta clínica. Além de reafirmar sua semiologia como reveladora principalmente para o paciente, ao contrário da clínica psiquiátrica, com sua semiologia reveladora para o médico.

É importante ressaltar também que nesse relato clínico, Freud deixa especialmente claro que não pretende fazer psicopatologia, descrever patologias, mas que, ao contrário, os acontecimentos referentes ao pequeno Hans constituem a propriedade comum de todos os homens, uma parte da constituição humana. O que ele pretende com seus casos clínicos é expor, demonstrar seu método e o campo a que este se aplica, o inconsciente.

Também no caso do Pequeno Hans, Freud insiste no novo estatuo que sua clínica concede ao sintoma como signo-enigma a ser revelado, definindo seu método como simultaneamente semiológico e terapêutico. Freud insiste, de forma aguda, na questão do desejo no desvendamento dos sintomas, estabelecendo definitivamente uma semiologia do desejo.

A esta altura da obra freudiana (1909), pode-se observar, portanto, já uma clínica completamente outra que não a tradicional psiquiátrica. Uma clínica que certamente 
traz uma abertura extraordinária para o encontro entre trabalhador e paciente. Mas, ainda assim, este encontro parece freqüentemente atravessado pela técnica psicanalítica, sobretudo pela interpretação psicanalítica.

O próximo caso clínico é também de 1909, tratase do texto "Notas sobre um caso de neurose obsessiva", conhecido como o "Homem dos Ratos". Nele, Freud, mais uma vez, retoma a diferenciação entre seu método e o da clínica psiquiátrica, reafirmando o método da clínica psicanalítica como um trabalho semiológico, e ao mesmo tempo terapêutico, de desvendar, revelar, traduzir os desejos e significados ocultos em funcionamento no inconsciente.

\section{Homem dos Ratos:}

É neste caso que Freud considera, com uma nitidez mais surpreendente que em seus outros casos clínicos, a importância decisiva da relação transferencial.

Até porque, com um pouco mais de atenção podemos recordar que, o pequeno Hans não era seu paciente, tampouco Schreber o era, e Dora encerrou seu tratamento antes que uma transferência pudesse se estabelecer.

Além disso, a transferência que se estabelece neste caso é uma transferência portadora de uma hostilidade e de uma agressividade, que representarão, para a condução de um caso clínico como este, certamente um grande desafio. Como se pode constatar em trechos como:

"Assim, somente pelo caminho doloroso da transferência é que foi capaz de se convencer de que sua relação com o pai realmente carecia da postulação desse complemento inconsciente. As coisas atingiram um ponto 
em que, em seus sonhos, em suas fantasias despertas e em suas associações, ele começou a acumular os mais grosseiros e indecorosos impropérios contra mim e minha família embora em suas ações deliberadas jamais me tratasse de outra forma senão com o maior respeito." ${ }^{290}$

E também:

"Assim, paulatinamente, nessa escola de sofrimento, o paciente logrou o sentimento de conviç̧ão que the faltava - embora a uma pessoa de fora a verdade fosse evidente quase por si mesma." 291

E ainda:

"Após atravessarmos uma série das mais severas resistências e das mais amargas injúrias de sua parte, ele não podia mais permanecer cego ao efeito esmagador da perfeita analogia entre a fantasia de transferência e o estado atual de acontecimentos passados. Repetirei um dos sonhos que ele teve nesse período, para fornecer um exemplo de sua maneira de tratar o assunto. Sonhou que ele via minha filha à sua frente; ela tinha dois pedaços de estrume em lugar dos olhos."292

Soma-se a esta preponderância da transferência neste caso, o fato, especialmente precioso para os propósitos desse estudo, que além do texto publicado por Freud, temos acesso também às anotações de sessões que serviram de

${ }^{290}$ Freud, 1989 [1909a], p. 209-210.

${ }^{291}$ Ibidem, p. 210-211.

292 Ibidem, p. 202. 
matéria bruta para a elaboração do artigo publicado.

Estas anotações, que de hábito eram destruídas por Freud, inexplicavelmente sobreviveram e foram encontradas em Londres, entre os papéis de Freud, após sua morte. Elas trazem descrições da relação transferencial que excedem em muito o exposto no material publicado, como nos trechos:

"Luta violenta, um mau dia. Resistência, porque ontem lhe pedi para trazer consigo um retrato da dama - quer dizer, para deixar de lado a sua reticência com respeito a ela. Conflito relativo a saber se ele abandonaria o tratamento ou cederia os seus segredos." ${ }^{293}$

E também:

"Enquanto ele colocar dificuldades em fornecer-me o nome da dama, seu relato será incoerente." 294

E ainda:

"Os temas são claros. Punição, à vista, pelo prazer que ele sentiu; ascetismo utilizando as técnicas da repulsa; raiva de mim por forçálo a [ficar ciente de] isso. Daí, o pensamento transferencial: 'Não há dúvida de que a mesma coisa acontece entre os seus flhos."'295

No mesmo sentido:

“'O senhor está se vingando de mim', ele disse. 'Está me forçando a fazê-lo, porque, por seu lado, deseja vingar-se de mim'."296

E também:

\footnotetext{
${ }^{293}$ Freud, 1989 [1909 a], p. 260.

294 Ibidem, p. 272.

295 Ibidem, p. 281-282.

296 Ibidem, p. 283.
} 
"Ele tinha um quadro de um dos juízes representantes, um sujeito sujo. Imaginou-o despido, e uma mulher praticava 'minette' [felação] com ele. De novo minha filha!"297

E ainda:

“'Agora o senhor irá me afastar.' Tratava-se de uma imagem minha e de minha mulher, na cama, e entre nós dois uma criança deitada, morta." 298

E também:

“Outra idéia horrível - a de ordenar-me que trouxesse minha filha até a sala, para que pudesse lambê-la, dizendo 'traga aqui a "Miessnick"'."'299

E continuando:

"Estava deitado de costas sobre uma jovem (minha filha) e copulava com ela pelas fezes que se desprendiam de seu ânus." ${ }^{300}$

Os diálogos transferenciais se sucedem ainda bem mais nesta mesma direção, com cenas macabras criadas pelo paciente, nas quais a mãe de Freud aparece em desespero enquanto seus filhos são enforcados, ou então, Freud e sua mãe surgem comendo excrementos, ou ainda, se imagina cuspindo no rosto de Freud, e também, realiza inúmeros insultos à mulher e à filha de Freud, e que o Prof. Freud "Ihe lamberia o cu", ou que o paciente mandaria o Prof. Freud "tomar no cu".

Como o próprio Freud repete algumas vezes, a situação neste tratamento era bastante difícil, com muitas lutas e assertivas, etc. E, é justamente esta possibilidade

${ }^{297}$ Freud, 1989 [1909a], p. 282.

298 Ibidem, p. 283.

299 Ibidem, p. 284.

300 Ibidem, p. 286. 
de acesso a esta intimidade do acontecimento terapêutico que torna este, certamente, o caso mais significativo para esse estudo, pois afora as notas dos atendimentos, o que temos no texto publicado é, mais uma vez, confirmações das teorias do Dr. Freud:

"Podemos considerar a repressão de seu
ódio infantil contra o pai como o evento que
colocou todo o seu modo de vida subseqüente
sob o domínio da neurose."

Então, fica bem evidente a dificuldade apresentada pelos casos publicados para se prestarem a uma abordagem do tipo que se pretende aqui, a de avaliar até que ponto, a partir do exercício clínico, há abertura para um acontecimento extra-clínico do cuidado.

De toda forma, também neste caso, Freud pode obter uma boa recuperação do paciente; e, ao mesmo tempo, boas confirmações de suas teorias do funcionamento do inconsciente, dos processos de formações sintomáticas:

"Quando achamos a solução descrita acima, o delírio que o paciente sofria sobre os ratos desapareceu." ${ }^{302}$

Assim, é retomando muitos pontos de sua teoria, que Freud delimita novamente seu método e seu campo de atuação, de uma forma que independe da patologia em questão, a neurose obsessiva. Mas, principalmente partindo das anotações das sessões, este caso apresenta uma importância toda especial para esse estudo. É que por ali, podemos vislumbrar melhor esse campo de batalha composto no encontro de Freud com esse paciente. Um encontro que, pelas anotações, parece mais franco e aberto que nas publicações.

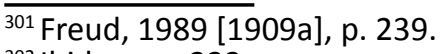

${ }^{302}$ Ibidem, p. 222. 


\section{Presidente Schreber:}

O texto "Notas psicanalíticas sobre um relato autobiográfico de um caso de Paranóia (Dementia Paranoides)", conhecido como o Caso Schreber, é o caso que Freud aborda em 1911.

Este caso não apresenta avanços no sentido da estruturação do método clínico freudiano. Na verdade, ele é um conjunto de considerações de Freud sobre a obra autobiográfica publicada por Schreber, quem jamais esteve em contado com Freud.

Neste sentido trata-se de uma tentativa de aplicar seu método clínico a um texto autobiográfico, tentando desvendar possíveis transferências de Schreber com seus médicos, e procurando desvendar, através destas prováveis transferências, os significados e desejos ocultos por trás da exuberante sintomatologia descrita com minúcias nas páginas desta autobiografia.

A contribuição desse caso, para esta discussão sobre a possibilidade de produção do cuidado a partir da psicanálise, é, em função destas características de ser um exercício puramente teórico de Freud, muitíssimo limitada.

Todavia, vale ressaltar três pontos bem interessantes deste caso.

O primeiro é que Freud, apesar de jamais ter atendido o paciente em questão, ressalta, mesmo neste caso, a importância da relação transferencial que Schreber estabelece com seus médicos, em particular o Dr. Flechsig.

Freud insiste, portanto, no caráter relacional dos tratamentos, na importância da tecnologia-leve (vide acima) que opera, para além dos conhecimentos psiquiátricos operantes, ou mesmo, apesar deles. 
O segundo ponto é que Freud, neste caso, lamenta suas limitações em poder abordar casos semelhantes a este, de psicose, em função também das possibilidades terapêuticas, e neste ponto, posteriormente acontecerá uma reviravolta, principalmente a partir de Lacan:

"Não podemos aceitar pacientes que sofram
desta enfermidade, ou, de qualquer modo,
mantê-los por longo tempo, visto não
podermos oferecer tratamento a menos
que haja alguma perspectiva de sucesso
terapêutico. Somente em cem circunstâncias
excepcionais, portanto, é que consigo
obter algo mais que uma visão superficial
da estrutura da paranóia - quando, por
exemplo, o diagnóstico (que nem sempre é
questão simples) é incerto o bastante para
justificar uma tentativa de influenciar o
paciente, ou quando, apesar do diagnóstico
seguro, submeto-me aos rogos de parentes
do paciente e encarrego-me de tratá-lo por
algum tempo."

Confirma-se, na abordagem freudiana deste caso, a necessidade da íntima relação terapêutica transferencial, onde o inconsciente se insinua, para que a clínica psicanalítica se realize. É por esta razão que neste caso clínico, apesar de serem extensas e suficientes as descrições psicopatológicas, os desvendamentos são modestos, restritos e com uma série de ressalvas e justificativas.

Esta ressalva que Freud coloca em relação à psicose, pode dar a entender, de certa forma, que a psicanálise se ocupa prioritariamente das neuroses. Este será um ponto bastante controverso no movimento psicanalítico, com posições absolutamente contrárias à impossibilidade de tratamento psicanalítico das psicoses, como a posição proposta pelo psicanalista francês Jacques Lacan.

$\overline{303}$ Freud, 1989 (1911]), p. 23. 
Abro aqui um parêntese, para explicitar esta posição de Lacan, dentro desta discussão do caso Schreber, por ser este caso o mote em torno do qual se constituirá a proposta lacaniana.

Lacan, em seu Seminário 3 - as psicoses, de 19551956, também trabalha sobre este caso do Presidente Schreber, igualmente a partir do livro deste engenhoso paciente "Memórias de Um Doente dos Nervos" 304 , e, claro, a partir da análise publicada por Freud.

Lacan, como referido em outra parte desse estudo, tem uma penetração importante na saúde mental em Minas Gerais, justamente em função de constituir-se em uma referência psicanalítica para o tratamento das psicoses. Sendo estas, por sua vez, o "público alvo" preferencial dos serviços substitutivos de saúde mental.

Neste seu Seminário 3, Lacan retomará a análise feita por Freud do livro de Schreber, primeiramente a partir da tríade, que lhe é cara, do simbólico, real, imaginário:

"Através desse lembrete, vocês já devem
ter reconhecido as três ordens sobre as
quais repiso para vocês o quanto elas são
necessárias a fim de compreender o que quer
que seja da experiência analítica - a saber: o
simbólico, o imaginário e o real."."

Em segundo lugar, tal retomada por Lacan, investe em um inconsciente estruturado como linguagem:

"Traduzindo Freud, dizemos - o inconsciente é uma linguagem. Que ela seja articulada nem por isso implica que ela seja reconhecida. A prova é que tudo se passa como se Freud traduzisse uma língua estrangeira, e mesmo a reconstituísse recortando-a. O sujeito está

$\overline{{ }^{304} \text { Schreber, } 1985}$ [1903].

${ }^{305}$ Lacan, 1988, p. 17. 
simplesmente, no que diz respeito à sua linguagem, na mesma relação que Freud. A se supor que alguém possa falar numa língua que lhe seja totalmente ignorada, diremos que o sujeito psicótico ignora a língua que ele fala." ${ }^{306}$

Em terceiro lugar, Lacan retoma a psicose a partir da "verwerfung" freudiana, fenômeno de exclusão também traduzido por foraclusão ou ainda forclusão - em contraposição ao recalque neurótico:

"Esse ponto é corroborado por outros textos, e especialmente por uma passagem tão explícita quanto possível, onde Freud admite um fenômeno de exclusão para o qual o termo Verwerfung parece válido, e que se distingue da Verneinung, a qual se produz em uma etapa muito ulterior. Pode acontecer que um sujeito recuse o acesso, ao seu mundo simbólico, de alguma coisa que no entanto ele experimentou e que não é outra coisa naquela circunstância senão a ameaça de castração. Toda a continuação do desenvolvimento do sujeito mostra que ele nada quer saber disso, Freud o diz textualmente no sentido do recalcado." 307

Em quarto lugar, essa retomada por Lacan passa pela relação entre o sujeito e o significante:

"No sujeito psicótico ao contrário, certos fenômenos elementares, e especialmente a alucinação que é a sua forma mais característica, mostram-nos o sujeito completamente identificado ao seu eu com o qual ele fala, ou o eu totalmente assumido através do modo instrumental. É ele que fala dele, o sujeito, o $\mathrm{S}$, nos dois sentidos equívocos do termo, a inicial S e o Es alemão. É

306 Lacan, 1988, p. 20.

307 Ibidem, p. 21. 
justamente o que se apresenta no fenômeno da alucinação verbal. No momento em que ela aparece no real, isto é, acompanhada desse sentimento de realidade que é a característica fundamental do fenômeno elementar, o sujeito fala literalmente com o seu eu, e é como se um terceiro, seu substituto de reserva, falasse e comentasse sua atividade." ${ }^{308}$

Em quinto lugar, a retomada lacaniana passa pela significação:

"Em oposição, há a forma que a significação toma quando não remete mais a nada. É a fórmula que se repete, que se reitera, que se repisa com uma insistência estereotipada. É o que poderemos chamar, em oposição à palavra, o ritornelo.

Essas duas formas, a mais plena e a mais vazia, param asignificação, é uma espécie de chumbo na malha, na rede do discurso do sujeito. Característica estrutural a que, já na abordagem clínica, reconhecemos a assinatura do delírio." ${ }^{309}$

Em sexto lugar, a retomada de Lacan passa pela estrutura:

"Mas, entretanto, graças a esse caso exemplar, e à intervenção de um espírito tão penetrante quanto o de Freud, nós nos vemos na posição de discernir pela primeira vez as noções estruturais cuja extrapolação é possível em todos os casos. Novidade fulgurante, e ao mesmo tempo iluminativa, que permite refazer uma classificação da paranóia em bases completamente inéditas." ${ }^{310}$

308 Lacan, 1988, p. 23.

${ }^{309}$ Ibidem, p. 44.

310 Ibidem, p. 37. 
Em sétimo lugar, retomada por Lacan a partir do Outro da linguagem:

“Na palavra verdadeira, o Outro, é aquilo diante do que vocês se fazem reconhecer. Mas vocês só podem se fazer reconhecer por ele porque ele é em primeiro lugar reconhecido. Ele deve ser reconhecido para que vocês possam fazer-se reconhecer." ${ }^{311}$

Em oitavo lugar, retomada lacaniana pelo discurso:

"Comecei por distinguir as três esferas da fala como tal. Vocês se lembram que podemos, no interior mesmo do fenômeno da fala, integrar os três planos, o do simbólico, representado pelo significante, 0 do imaginário, representado pela significação, e o do real, que é o discurso de fato efetuado realmente em sua dimensão diacrônica.

\section{(...)}

A noção de discurso é fundamental. Mesmo quanto ao que chamamos objetividade, 0 mundo objetivado pela ciência, o discurso é essencial, pois o mundo da ciência, que se perde sempre de vista, e acima de tudo comunicável, ele se encarna nas comunicações científicas." ${ }^{312}$

Em nono lugar, retomada lacaniana através do significante primordial Nome-do-Pai:

"Aí se encontra manifestamente o mecanismo do como se que a Sra. Helena Deutsch avaliou como uma dimensão significativa da sintomatologia dos esquizofrênicos. É um mecanismo de compensação imaginária verifiquem a utilidade da distinção dos três

311 Lacan, 1988, p. 63.

${ }^{312}$ Ibidem, p. 78. 
registros, - compensação imaginária do Édipo ausente, que lhe teria dado a virilidade sob a forma, não da imagem paterna, mas do significante, do nome-do-pai." ${ }^{313}$

Toda esta retomada feita por Lacan gira em torno deste mesmo caso Schreber, seu relato autobiográfico e a análise feita por Freud.

Fechando este parêntese aberto para me referir a Jacques Lacan, no contexto do caso Schreber, tendo a constatar que, seu posicionamento estruturalista abre um risco para uma nova rigidez diagnóstica - agora o diagnóstico estrutural - no encontro com o usuário, ainda que, por outro lado, possa ser geradora de aberturas, ao considerar os fenômenos psicóticos como questões concernentes à linguagem.

Mas, quero recuperar após este parêntese, o fio condutor que me levava a apontar três pontos relevantes neste caso, sendo o terceiro ponto, o fato de que este caso Schreber me parece absolutamente exemplar de uma produção extra-clínica.

Produção para além da clínica, não a partir da psiquiatria ou da psicanálise, freudiana ou lacaniana, mas produção de vida a partir da obra do próprio Schreber, sua magnífica "Memórias de um Doente dos Nervos", que está intimamente ligada a uma campanha pessoal, junto ao Real Tribunal de Dresden, pela recuperação de seus direitos de viver sua vida, de conviver com sua gente.

E esta produção é coroada de sucesso quando obtém vitória, graças aos seus próprios méritos, junto à Corte de Apelação de Dresden, recuperando sua própria vida, por assim dizer:

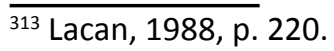


"No tempo decorrido desde o início do trabalho, modificaram-se essencialmente as condições externas de minha vida. Enquanto no início eu vivia em uma reclusão quase carcerária, excluído do contato com pessoas cultas e até mesmo da mesa familiar do diretor do sanatório (acessível aos chamados pensionistas), nunca saía fora dos muros do sanatório, etc., foi-me sendo pouco a pouco concedida maior liberdade de movimento e possibilitado cada vez mais o relacionamento com pessoas instruídas. Consegui finalmente (embora apenas em segunda instância) total ganho de causa no processo de interdição citado no capítulo XX, uma vez anulada a sentença de interdição determinada pelo Real Tribunal de Dresden, por decisão, hoje juridicamente válida, da Corte de Apelação de Dresden, a 14 de julho de 1902. Minha capacidade legal de trabalho foi então reconhecida e restituída a livre disposição de meus bens. Quanto à minha permanência no sanatório, tenho em mãos já há alguns meses uma declaração escrita da direção, segundo a qual nenhuma objeção de princípio se opõe à minha alta; por este motivo penso retornar à minha casa a partir do início do próximo ano." 314

Neste sentido, podemos reconhecer em Schreber o exemplo mais significativo de exercício da tragicamentalidade. Sobretudo quando, em suas petições e apelações à justiça, conciliava todo seu raciocínio e habilidade apolínea, socrática, racionalista, e, ao mesmo tempo, sem jamais abrir mão, sem jamais negar ou escamotear sua paixão delirante, seu lado absolutamente dionisíaco, criando um quadro absolutamente dionisíacoapolíneo.

$\overline{314}$ Schreber, 1985 [1903], p. 25-26. 
Schreber assim, conseguia intervir por dentro da governamentalidade, conhecendo, por força de seu ofício, seu funcionamento até a última filigrana, e criando fissuras, espaços de tragicamentalidade, da qual era incomparavelmente portador.

Passo agora ao último dos cinco grandes casos clínicos publicados por Freud.

\section{Homem dos Lobos:}

O último dos mais importantes casos clínicos de Freud é o texto "História de uma Neurose Infantil", de 1918 [1914], conhecido como o Caso do "Homem dos Lobos".

Esse caso não apresenta novidades significativas no que se refere ao método da clínica psicanalítica. $O$ texto constitui-se sim em uma reafirmação amadurecida das peculiaridades, especificidades do método, como um contínuo desvendar enigmas, revelando significados e desejos ocultos; considerando sempre a importância capital da relação transferencial que perpassa todo o relato clínico.

Freud retoma a proposta de não colocar em primeiro plano as distinções nosográficas ou psicopatológicas, mas antes assumir que o que está sendo revelado é algo pelo qual todos nós tenhamos passado.

Convém, porém, ressaltar que, neste e nos outros casos, Freud assume uma postura de, paralelamente ao processo de demonstração de sua semiologia e dos resultados possíveis a partir desta, elaborar também, neste novo campo - o inconsciente -, uma descrição de seus mecanismos de funcionamento em cada patologia abordada. 
Esta descrição ocorre, geralmente, como último capítulo dos casos clínicos, ganhando um tom de anexo ou adendo, no qual ele possivelmente procuraria se redimir um pouco de sua ruptura epistemológica, abordando o inconsciente, descrevendo-o, segundo uma semelhança com a tradição da clínica médica em geral, ou psiquiátrica em particular.

Neste aspecto, pode-se referir essa descrição dos mecanismos inconscientes em cada patologia, como uma psicopatologia psicanalítica, processo que, volto a dizer, apresenta-se claramente como acessório nos textos freudianos abordados.

Do ponto de vista da técnica clínica da psicanálise, este é possivelmente o caso mais importante, o mais elaborado, no qual apenas a primeira fase de tratamento já durou mais de quatro anos:

\begin{abstract}
“Este é o mais elaborado e sem dúvida o mais importante de todos os casos clínicos de Freud. Foi em fevereiro de 1910 que o jovem e rico russo, de quem o relato trata, dirigiu-se a Freud para ser analisado. Sua primeira etapa de tratamento, que é abordada neste artigo, durou daquela data até julho de 1914, quando Freud considerou o caso encerrado." 315
\end{abstract}

Porém, o caso não estava encerrado como supunha Freud, e o jovem russo, após o término desta primeira fase teria desenvolvido um quadro possivelmente persecutório em relação a Freud:

"Ele veio, então, para Viena e informou-me que imediatamente após o fim do tratamento fora presa de uma ânsia de livrar-se de minha influência. Depois de alguns meses de esforço, uma parte da transferência, que até então

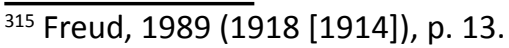


não fora superada, foi resolvida com êxito." ${ }^{316}$

Um êxito temporário, já que o jovem volta a tratar-se com Freud em 1919-1920. E posteriormente, o rapaz passa a ser tratado, a conselho de Freud, pela Dra. Ruth Brunswik em 1926-1927, e depois com acompanhamento até 1940.

O que Freud reencontra, no caso deste rapaz - que se recusava a aceitar a castração, que sonhava com lobos, que na verdade representavam seus pais e a relação sexual entre eles - como seu próprio título indica "história de uma neurose infantil", são as origens do adoecimento deste jovem em sua sexualidade infantil:

\begin{abstract}
"Aos olhos de Freud, o significado primário deste caso clínico na época de sua publicação era claramente o apoio que proporcionava para as suas críticas a Adler e, mais especificamente, a Jung. Havia ali evidência conclusiva para refutar qualquer negação da sexualidade infantil." ${ }^{317}$
\end{abstract}

Também neste caso, o Édipo reina soberano, os temas e as concepções freudianas ressurgem em um carrossel, e não se pode ver muita abertura para a possibilidade de se produzir um cuidado extra-clínico:
“(...) a análise imergiu outra vez no período pré-histórico e induziu-o a afirmar que durante a cópula, na cena primária, ele observara o pênis desaparecer, que sentira pena do pai por causa disso e que se alegrara com o reaparecimento daquilo que achara que estava perdido." 318

Contudo, apesar de os relatos clínicos apresentarem uma estética racionalista, socrática, que cria pouca oportunidade para uma abertura trágica, para a 
tragicamentalidade, para o acontecimento do cuidado na clínica psicanalítica; antes de encerrar este tópico, preciso fazer duas ressalvas que me parecem importantes.

A primeira é que, em relação à clínica propriamente lacaniana, vale ressaltar que o Seminário 3, exposto acima, está inserido em um contexto habitualmente denominado de "primeira clínica" lacaniana, uma clínica mais estruturalista, baseada na fixação das estruturas clínicas neurose, psicose, perversão.

Mas que, há outra clínica lacaniana, mais fluida, e menos fixada em diagnósticos estruturais; portanto, possivelmente com mais abertura ao encontro com a multiplicidade do paciente, que pode ser denominada "clínica do gozo":

“É exatamente esta a dificuldade daquele que tento aproximar tanto quanto posso do discurso do analista - ele deve se encontrar no pólo oposto a toda vontade, pelo menos confessada, de dominar. Disse pelo menos confessada não porque tenha que dissimulála mas porque, afinal, é sempre fácil voltar a escorregar para o discurso da dominação, da mestria.

\section{(...)}

No entanto, é claro que nada é mais candente do que aquilo que, do discurso, faz referência ao gozo.

O discurso toca nisso sem cessar, posto que é dali que ele se origina. E o agita de novo desde que tenta retornar a essa origem. É nisso que ele contesta todo apaziguamento." ${ }^{319}$

A segunda ressalva antes de passar ao próximo tópico é um último caso clínico, tratado em psicanálise, que eu 319 Lacan, 1992, p. 65-66. 
não poderia deixar de incluir nesta discussão a propósito da possibilidade de produção de cuidado, do trágico em sua estética, da tragicamentalidade nesta produção de cuidado.

Um caso clínico do qual tenho a vantagem de poder falar com toda a propriedade, mas, ao mesmo tempo, a desvantagem, de colocar frente a sua exposição uma série de restrições pessoais; uma vez que estou me referindo ao meu próprio tratamento.

Ao pensar teoricamente as possibilidades que a psicanálise cria em seu campo de atuação, para o acontecimento do cuidado, para um exercício de tragicamentalidade, não poderia me furtar de considerar, também, o que pude experimentar pessoalmente, de uma forma absolutamente concreta, viva em ato, como analisando, como paciente em análise regular por sete anos.

E o que tenho a testemunhar é que vivenciei um processo extremamente cuidador, compromissado absolutamente com a produção de vida, em toda sua dimensão trágica, e acima de qualquer compromisso com uma verificação teórica, ou uma filiação discursiva, ou uma mera regulamentação da vida.

Certamente que nem sempre é assim, e que, nas três clínicas que estou abordando neste estudo, justamente por se realizarem no trabalho vivo em ato, a possibilidade do cuidado acontecer, da tragicamentalidade ser exercida, está aberta, mas de forma alguma garantida.

Creio ser possível dizer também que, quanto maior o compromisso do operador do cuidado, com suas filiações discursivas a estas tecnologias clínicas, menor a possibilidade do cuidado, esse excedente da clínica, acontecer; portanto, menor a possibilidade da tragicamentalidade, esse excedente da governamentalidade, se exercer. 
Passarei agora à terceira tecnologia clínica abordada aqui.

\section{Clínica Psicossocial}

Começo a relembrar uma série de autores que descrevem uma clínica ampliada, que no campo da saúde mental aproxima-se do conceito de Atenção Psicossocial, e dos Centros de Atenção Psicossocial, chamados CAPS, como segue abaixo.

Inicio com Jairo Golgberg ${ }^{320}$, que relata a experiência clínica no primeiro CAPS do Brasil, o Prof. Luiz da Rocha Cerqueira, em São Paulo.

Este autor aponta como características do trabalho terapêutico no CAPS: o entrecruzamento de diversas concepções de tratamento, a recusa do modelo sintomatológico, com o deslocamento do foco da clínica da doença para a pessoa do doente; um conjunto terapêutico intensivo e múltiplo condizente com a complexidade desta clínica (atendimentos individuais e em grupo, esforços socializantes, atendimento familiar, atenção diária e constante, reabilitação); uma clínica operativa e também ética; um trabalho em processo e renovação, buscando galgar novos patamares de existência para os sujeitos; uma consideração da linguagem como meio de produção dos sujeitos; uma abordagem prolongada, sem fixação de prazos e com instâncias de escuta de expressão verbal e não verbal; um compartilhamento do cotidiano; um acolhimento e tratamento também da família, com espaços coletivos de fala e expressão; uma construção de projetos terapêuticos individuais e exclusivos para cada paciente; múltiplas oficinas e ateliês onde se está atento à emergência

$\overline{{ }^{320} \text { Goldberg, } 1996 .}$ 
da fala e dos laços transferenciais; uma permanente ruptura com o isolamento, buscando fluxos existenciais e sociais emancipatórios; uma articulação com o contexto de vida, e intervenções nas condições objetivas do paciente; estratégias de sustentação do contato, como visitas domiciliares; agenciamentos da vida dos pacientes, como direitos previdenciários, moradia, transporte; ações extramuros e intersetoriais, buscando novas trocas e novos laços, instâncias permanentes de mediação social no processo emancipatório da doença; valorização da capacidade, da potência de intervenção do paciente na vida cotidiana e na constituição do próprio projeto; reajuste permanente das relações cotidianas entre pacientes, técnicos, familiares, instituição, considerando sempre o campo transferencial; assembléias de usuários, reuniões clínicas freqüentes, discussão permanente do projeto e da instituição; uma busca de um continuum de suporte à vida e de coeficientes de escolha cada vez maiores no gerenciamento da própria vida.

Considerada desta maneira, a clínica parece atingir uma amplitude que não tem fim, avançando simultaneamente em todas as direções do existir ou do viver.

Neste aspecto, Goldberg apresenta o conceito interessante de "gestão extra-clínica da vida" 321 , apontando para a necessidade de se colocar limite à clínica, neste momento em que as mais variadas dimensões se agregam ao trabalho assistencial.

Passo a Jurandir F. Costa ${ }^{322}$, que considera a clínica no CAPS um novo modo de se fazer psiquiatria, uma psiquiatria pragmática, que abre mão de fidelidades teóricas ou doutrinárias, pelo uso de todos os recursos ou o melhor recurso, em cada momento, para superar toda $\overline{321 \text { Goldberg, } 1996 .}$

${ }^{322}$ Costa, 1996. 
sorte de impasses que se apresentam na recuperação da força normativa destes sujeitos.

Estes impasses, "que vão desde o desemprego até os conflitos típicos das ações intencionais, que o levam a ser diagnosticado como psicótico" ${ }^{323}$, requerem toda uma gama de respostas que podem incluir, em dado momento, medicação, em outro, psicoterapia, ou outra "tática teóricoprática" que possa restituir a habilidade normativa destes sujeitos.

Jurandir insiste que a clínica no CAPS é "acompanhar, passo a passo, a trajetória de vida das pessoas" ${ }^{124}$, sem compromissos ontológicos universais, mas pautado pela ética, perguntando "a cada etapa da assistência, o que representa para o sujeito moral ser definido a partir de tal ou qual enquadre teórico" ${ }^{325}$, considerando sempre "o que ele ganha ou perde em autonomia, respeito por si próprio e pelo outro, quando exposto a certos procedimentos terapêuticos." ${ }^{26}$ Portanto, uma clínica movida pela "moral da solidariedade e não da objetividade" ${ }^{327}$, pelo "ideal ético da comunidade de tradição à qual pertencem psicóticos e profissionais da assistência." 328

Ana M. F. Pitta refere-se à produção do cuidado no CAPS como "clínica condizente com a cidadania ativa e ampliada que tanto desejamos" 329 , pautada por "um cuidado personalizado, inserido num enquadre ético de não abandono, ou seja, um cuidado responsável" ${ }^{330}$, que busque a produção de subjetividade e a singularização.

\footnotetext{
${ }^{323}$ Costa, 1996.

324 Ibidem.

325 Ibidem.

${ }^{326}$ Ibidem.

327 Ibidem.

328 Ibidem.

${ }^{329}$ Pitta, 1996.

330 Ibidem.
} 
E insiste no caráter criativo e inventivo do CAPS, em que se desenvolve:

“(..) uma tecnologia de cuidados que considere um compromisso ético de acolher e cuidar de pessoas culturalmente desinseridas, socialmente abominadas, transfigurando-as em sujeitos amorosos, passíveis de alguma inteligibilidade, de provocar simpatia, solidariedade, alianças terapêuticas." 331

Esta mesma autora recorda a proposta de ruptura com o paradigma clínico, pertinente historicamente aos primeiros momentos de tomada de posição contra os hospícios, e a considera não ser mais adequada, quando novas clínicas estão operando uma práxis na qual "tolerância e ousadia configuram campos especiais para a produção de novos saberes e novas regras de contratualidade social entre os que atendem e os que são atendidos." ${ }^{332}$

A polêmica quanto ao lugar da clínica, ou de uma anti-clínica como superação paradigmática, existiu ou ainda existe, em maior ou menor medida, na trajetória de inúmeros CAPS.

Por um lado, pode-se considerar que uma práxis verdadeiramente transformadora da relação loucura-razão deveria buscar justamente a superação do paradigma clínico, constituído por formas variadas de objetivação, reificação, domesticação, redução, submissão, controle, sujeição ou mesmo desqualificação, negação, extinção da experiência da loucura.

Por outro lado, o CAPS não pode se furtar ao fato das necessárias práticas de cuidado, de atenção à saúde, dirigidas aos portadores de sofrimento mental grave, psicóticos.

332 Ibidem. 
Sendo a clínica, um "dispositivo", social e historicamente construído e reconhecido, para enfrentar tais condições de sofrimento, reconhecidas, em menor ou maior grau, como adoecimento, ainda que passando este a ficar entre parênteses, uma vez que, a relação loucurarazão não se encontre mais sob o paradigma de doença da visão predominante do modelo médico reducionista.

Mas é importante ressaltar que este debate da anti-clínica, ou, em certa medida, da antipsiquiatria, não coincide com esta discussão que estou fazendo a propósito do cuidado para além da clínica. Sua perspectiva é bem diferente, e suas possíveis repercussões certamente distintas.

Para Silvio Yasuy, o trabalho desenvolvido no CAPS se caracteriza pela:

“(...) produção de sentido, de invenção, de encontro, de busca e - por que não? - de prazer. $^{\prime 333}$

Uma clínica "fundada num radical compromisso com a vida" 334 , na qual o "usuário é o centro da atenção" ${ }^{335}$, e participa ativamente da determinação de seu percurso terapêutico, buscando o pleno exercício da cidadania. Um trabalho que coloca em questão não uma doença, "mas sim um sofrimento, uma singularidade, uma subjetividade" ${ }^{336}$, tendo por finalidade ampliar e diversificar "as possibilidades de intervenção e invenção terapêuticas, criando condições para favorecer que o usuário possa, a seu modo e a seu tempo, descobrir (perceber? Construir?) algum sentido, seu sentido, sua verdade." ${ }^{337}$

\footnotetext{
${ }^{333}$ Yasui. 1989.

334 Ibidem.

335 Ibidem.

$336 \mathrm{lbidem}$.

${ }^{337}$ Yasui. 1989.
} 
Cláudia M. F. Penido, referindo-se aos CAPS da cidade de Belo Horizonte, aponta como características desta inovação assistencial: a lógica do acolhimento, a "lógica de responsabilização pelo paciente" ${ }^{\prime 338}$, a superação da fragmentação do paciente pela equipe multiprofissional que ocorria no modelo biopsicossocial, a psicanálise, ou a referência ao sujeito do inconsciente, como conhecimento abstrato, dividindo a hegemonia do saber psiquiátrico, o engajamento e desterritorialização das profissões não psi com a exigência da disponibilidade para a inventividade clínica.

Ana Marta Lobosque aponta, como diretriz de um novo cuidado com a loucura, o "tornar cada vez mais fluidas, mais transitáveis, mais flexíveis, as fronteiras entre as instituições destinadas a eles e a sociedade onde se desenrola a vida e o destino de todos nós, loucos ou não." 339

Esta mesma autora considera que a clínica substitutiva trabalha pela autonomia e independência das pessoas, ao contrário da tradicional função de controle social da Saúde Mental, compondo um cuidar com "uma ajuda que se exerça sem domínio" ${ }^{340}$, lançando mão dos recursos, saberes, tecnologias disponíveis, "mas sempre subordinando seu emprego a um projeto que não é psiquiátrico ou psicológico, mas político e social" ${ }^{341}$, visando "dar lugar à alegre afirmação do desejo." ${ }^{342}$

A esta clínica Lobosque nomeia "clínica em movimento", pois se "articula com tudo o que se movimenta e se transforma na cultura, na vida, no convívio entre os homens. ${ }^{343}$ Neste sentido um CAPS deveria ser um espaço

\footnotetext{
338 Penido. 2005.

339 Lobosque. 2003.

340 Ibidem.

341 Ibidem.

342 Ibidem.

343 Ibidem.
} 
de circulação intensa e incessante, compatibilizando o enfrentamento cotidiano das crises com o "zelo pela liberdade", buscando "fechar apenas o estritamente necessário para que se possa abrir sempre e mais." ${ }^{344}$

A mencionada autora descreve um CAPS da cidade de Belo Horizonte como um lugar público que as pessoas freqüentam, um lugar de passagem, com um acolhimento ativo e incondicional, evitando a inércia, buscando "convidar as pessoas para empreendimentos e projetos" ${ }^{345}$, promovendo um convívio, sem negligência, violência ou abandono. Um lugar para "promover a criação e o riso, as trocas e os trânsitos" ${ }^{346}$, em um trabalho "de escutar e ponderar, decidir sem arbitrariedade e negociar sem imposição" ${ }^{347}$, com o recurso a atividades coletivas, construindo práticas inovadoras e criativas, destemidas, insubmissas e vivas, compondo laços, em direção a "uma transformação da presença da loucura na cidade." ${ }^{\prime 348}$

Esta mesma autora ressalta a importância da psicanálise para a clínica nos CAPS, com seu corpo teórico inventivo e rigoroso, com seu "sujeito do inconsciente, descentrado, partido, fora-de-sentido" ${ }^{349}$, mas com a ressalva de não reconhecer aí uma fundamentação teórica que poderia engessar estas "práticas que encontram sua eficácia justamente em seu caráter descentrado, disperso, descontínuo, local, indiferente a qualquer tipo de autentificação universalizante ${ }^{350}$, retomando a politização do desejo e recusando a oposição asséptica entre clínica e política.

\footnotetext{
344 Lobosque. 2003.

345 Ibidem.

346 Ibidem.

${ }^{347}$ Ibidem.

${ }^{348}$ Ibidem.

349 Ibidem.

350 Ibidem.
} 
A clínica no CAPS, ainda com Lobosque, "visa possibilitar a presença, a circulação, e a ação dos portadores de sofrimento psíquico no espaço social" ${ }^{351}$, fazendo prevalecer o cuidado e não a vigilância, a vida e não as normas, fazendo caber a loucura entre nós, ou seja, no espaço social, buscando "o mover-se e o acontecer da vida" ${ }^{352}$, sem qualquer tutela, rumo à reinvenção, à criatividade, à transformação social, possibilitando "processos de subjetivação que reinventam a política, a economia, as estruturas sociais." 353

Costa-Rosa, Luzio e Yasui consideram a clínica no CAPS como encontro gerador de cuidado, acolhimento, emancipação e "contratualidade social entendida como aumento das trocas de bens, de mensagens e de afetos ${ }^{\prime \prime 354}$, criando espaços de circulação, "de sociabilidade, de trocas, em que se enfatiza a produção de saúde como produção de subjetividades. ${ }^{\prime 355}$

Segundo estes autores, a clínica da atenção psicossocial se caracterizaria pelo tratamento da demanda e não dos sintomas, pela escuta e criação de si, pela tomada do sujeito como sujeito e não objeto, pelo paradigma existência-sofrimento e não doença-cura, pela desospitalização, desmedicalização, transdisciplinaridade, horizontalização das relações, livre trânsito e participação ativa dos usuários, interprofissionalidade integradora, interlocução, integralidade, responsabilidade sobre Teritório, reintegração socioeconômica e cultural, singularização pela implicação subjetiva e sociocultural.

Para Paulo Amarante, o CAPS deveria ser

\footnotetext{
351 Lobosque. 2003.

352 Ibidem.

353 Ibidem.

${ }^{354}$ Costa-Rosa; Luzio; Yasui, 2003.

355 Ibidem.
} 
“(...) um serviço inovador; isto é, espaço de produção de novas práticas sociais para lidar com a loucura, o sofrimento psíquico, a experiência diversa; para a construção de novos conceitos, de novas formas de vida, de invenção de vida e saúde." ${ }^{\prime 35}$

A clínica neste espaço é um processo permanente de invenção, gerando "competências em lidar com a loucura" 357 , construindo "novas formas de lidar, de escuta, de reprodução social dos sujeitos"358, acolhendo, cuidando, interagindo, inserindo, dentro de um "processo ético-estético, de reconhecimento de novas situações que produzem novos sujeitos, novos sujeitos de direito e novos direitos para os sujeitos. ${ }^{1359}$

Amarante considera preciso "reinventar a clínica como construção de possibilidades, como construção de subjetividades ${ }^{1360}$, ocupando-se dos sujeitos com sofrimento psíquico, com responsabilização, centrado no cuidado e na cidadania, evitando o risco de que, com a clínica ampliada, tudo se torne clínica.

Antônio Lancetti propõe para os CAPS uma clínica "pelo território geográfico e pelo território existencial" ${ }^{361}$, com uma exacerbação da complexidade, atendendo de portas abertas, priorizando os casos mais graves e difíceis, mantendo estreito relacionamento com o Programa de Saúde da Família, oferecendo assistência integral e territorializada, exercendo "uma microssociologia de fundamento vital e uma pragmática solidária."362

Abílio da Costa-Rosa caracteriza a clínica psicossocial,

\footnotetext{
${ }^{356}$ Amarante, 2003c.

357 Ibidem.

358 Ibidem.

359 Ibidem.

360 Ibidem.

${ }^{361}$ Lancetti, 2006.

362 Ibidem.
} 
que seria portanto a do CAPS, como aquela que considera os "fatores políticos e biopsicossocioculturais como determinantes" 363 , lançando mão de "um conjunto amplo de dispositivos de reintegração sociocultural" ${ }^{364}$, além das psicoterapias, socioterapias, medicação, etc.

Para este autor o modo psicossocial tem por objeto toda a existência-sofrimento dos sujeitos-cidadãos, causando uma "ampliação do conceito de tratamento e do conjunto de meios a ele dedicados" 365 , em um "verdadeiro exercício estético" 366 , ou ético-estético, visando novas possibilidades de ser.

Tal exercício ético-estético concorre por meio de uma "desospitalização, desmedicalização e implicação subjetiva e sociocultural" ${ }^{367}$, e ainda, "participação, autogestão e interdisciplinaridade"368, e também, "interlocução, livre trânsito do usuário e da população, e Territorialização com Integralidade ${ }^{\prime 369}$, causando um reposicionamento subjetivo e sociocultural na direção da singularização, da horizontalização e interlocução.

André Martins salienta a criação individual "que expressa a cada vez a singularidade originária e présimbólica que somos, no tempo e na vida"370 como constitutiva desta clínica que deve pensar sua eficácia pelo "aumento da potência de agir e do amor à vida, como um todo, por parte do próprio indivíduo."371

Como se pode constatar é inequívoco o benefício

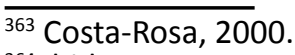

364 Ibidem.

365 Ibidem.

366 Ibidem.

${ }^{367}$ Ibidem.

368 Ibidem.

369 Ibidem.

370 Martins, 2000.

371 Ibidem.
} 
para os usuários, que práticas clínicas, direcionadas por estas conceituações, geram e continuarão gerando.

Porém, insisto nessa possibilidade de pensar um fora da clínica, um produzir cuidado para além da clínica, sem desprezá-la, sem descartá-la.

Como estaria acontecendo em ato, a aplicação destes propósitos conceituais? Vejamos uma descrição no contexto psicossocial.

\section{Linha Gomes Jardim}

"A casa da rua Gomes Jardim pertence à Prefeitura Municipal de Porto Alegre. Quando realizamos a pesquisa, possuía seis moradores. O Sr. J., antigo residente de uma clínica psiquiátrica, acompanhou todas as mudanças da saúde mental ao longo dos últimos trinta anos. Ele analisou as diferenças entre o hospital e a sua residência atual:

'A principal diferença é a liberdade. No hospital, a gente é tolhido, a gente não pode sair para fora, a não ser em situações excepcionais. E aqui a gente pode sair, a gente tem de cuidar do prédio, tem que ser responsável pelo prédio. Temos que viver aqui e a liberdade é total. Nós podemos fazer o que nos dá na cabeça. Nós ficamos conhecendo o comércio aqui da zona.'

B. é outro morador da casa. De certa forma, ele dá continuidade às análises do Sr. J.

'Eu tô em tratamento há mais ou menos vinte anos. Tratamento psiquiátrico. E o único lugar que eu achei que tava bom era aqui, que era bom de se tratar e existia uma certa ponderância no tratamento, não era só conter 
o paciente, só conter com remédio. Tinha muito isso lá na L. Outra internação foi no $\mathrm{H}$. Lá eles davam muito remédio pra gente. Com o tratamento parecia que nós tava sempre em surto. Mas faz parte do tratamento deles, do métodos deles, dar remédio pra gente.

Tive no F. também. Não gostei. A prioridade é o tratamento, não tinha muito a parte social, afetiva do paciente. $\mathrm{E}$ a gente não tinha contato com a sociedade. Tinha que ficar encerrado lá como mais um número, ou um animal. E eles falam das drogas, mas o remédio deles também é uma droga, que eles aplicam na gente e a gente fica sem personalidade, fica vazio, fica meio bobo, meio trancado, sabe. Aqui tem contato com a sociedade, tem vontade, tem personalidade, pode, se quiser, dizer não, não tem pressão. Outra coisa que aqui é muito bom é que a gente não pode reclamar da gente mesmo, porque ta tudo sob o nosso controle, a alimentação, o sono, a saída pra trabalhar. Eu tô na oficina de geração de renda, faço serigrafia.'

\section{Como era a vida?}

'Não adiantava eu me tratar e não ter a parte social. Eu tinha muitos problemas em casa, me tornava violento, brigava com os vizinhos, com os traficantes. Eu morava na vila J, em Porto Alegre. Então eu precisava de uma mudança maior, não adiantava mudar poucas coisas. Talvez apareçam alguns problemas mais tarde, mas por enquanto tá muito bom aqui. Aqui a gente tem chance de sair, lidar com dinheiro. A gente aprende a se automedicar. Não se automedicar de forma errônea, mas tomar seu próprio remédio, na hora certa. 
Aqui a gente vai na farmácia, busca o próprio remédio, vai falar com seu próprio médico, pode trocar de médico. Se quiser trocar de médico, pode trocar de médico. Aqui a gente ganha vistoria do pessoal técnico, vem a enfermeira, vem a coordenadora. $E$ no momento que eles vêm nos acolher, vêm nos ver, eles também têm aquela questão de orientar a gente, vê o que tá certo e o que tá errado e dão uma orientação pra gente viver melhor. Não que a gente vai ficar atirado num canto, fazendo o que bem entende, não é isso.'

Nossa conversa se torna mais científica. Por que os hospitais ainda mantêm o tratamento manicomial?

'Porque tinha uma coisa de herança, um médico passou para outro. Eles achavam que eu era muito violento. Eu não queria ir. Por causa que eu tinha briga com meus vizinhos, que eram traficante, marginal. Então eu tinha uma causa e tinha uma conseqüência mas, pelo ponto de vista médico, eu era violento demais, tinha que ser medicado.

Acho que o primeiro passo está sendo dado. O segundo é aproximar mais o paciente, o usuário da sociedade. Porque ele não é propriamente um louco, um doente, um insano. Ele tem um "eu", e também ta sendo mudado isso. O que mais poderia ser feito é isso, trazer mais para o contato da sociedade. A sociedade tem que evoluir também nesse aspecto, procurar entender a doença do usuário ou o problema. Às vezes não é uma doença, é um problema. E pode se tornar grave se não for tratado, isso é verdade. Mas nem por isso eles têm que ser tratados daquela forma, como se já fosse doente, como se já fosse incapaz. Já é discriminado 
desde aí. E se trouxer para o público, pra sociedade, e a sociedade tiver aceitação, já é um segundo passo.

A outra questão é financeira, que teria que qualificar o usuário pra que ele pudesse ter mão-de-obra, ter seu dinheiro, ter seu trabalho, ter sua festinha, ter seus amigos e isso tudo que uma internação fechada não tem. Ter sua vontade de se expandir, divertir, brincar. Se ficar brincando sozinho é louco, eles acham. Eu mesmo não acredito nisso. Eu acredito que ta certo, tem um problema, tem um problema, mas é controlável.'"372

É bastante evidente a abertura de possibilidades que se apresentam neste contexto psicossocial. O testemunho dos usuários a este respeito é inequívoco.

É certo que este material não representa exatamente um caso clínico, mas um relato de moradores de um dos dispositivos inventados pela reforma psiquiátrica, os serviços residenciais terapêuticos.

Mas também é certo, como os usuários reconhecem aí, em suas falas, não apenas uma forma de morar, mas uma nova forma de serem tratados, que podem comparar com a forma anterior, hospitalar.

E tal comparação aponta para uma vida que agora pode pulsar. Mas, ainda assim, no que se refere à condução dos casos operada pelos trabalhadores da saúde, no contexto psicossocial, há um leque de possibilidades que vão desde uma postura mais técnica, racionalista, até uma postura baseada fundamentalmente no convívio, sobretudo, pelos profissionais sem formação clínica específica.

Persiste aí, nas mais variadas situações, a indagação sobre o espaço para uma produção de cuidado, e 372 Perrone; Engelman, 2007, p. 178-80. 
conseqüentemente para a possibilidade de uma estética do trágico, para o exercício da tragicamentalidade.

Para Emerson Merhy, a produção do cuidado em saúde deve dirigir-se para "ganhos de autonomia e de vida dos seus usuários" 373 , permitindo o nascer "de novas possibilidades desejantes, protegidas em redes sociais inclusivas" 374 , de forma a "vivificar o sentido da vida no outro." 375

Merhy ressalta então a produção do cuidado, inclusive com essa possibilidade de descolamento da clínica, sobretudo perante os novos riscos da clínica do corpo sem órgãos. ${ }^{376}$

"De posse dessas ideias-conceitos, ou imagem, pode-se perguntar: será que hoje, o que está em foco na saúde- como forma de dar substância aos seus mecanismos de biopoderes - não seria centralmente operar uma biopolítica, nas relações de poder da sociedade, sob o predomínio das estratégias de controle (subsumindo as disciplinares), onde esta vai atuar de maneira direta e frontal, isto é: nas formas de construção e produção do desejo, ultrapassando as ações de pura submissão, do vigiar e punir, ao intervir na construção dos modos de viver, a partir dos corpos sem órgãos? Ou seja, enquanto pura virtualidade a se tornar território existencial e identitário." ${ }^{377}$

\footnotetext{
373 Merhy, 2004.

${ }^{374}$ Ibidem.

375 Ibidem.

${ }^{376}$ Deleuze; Guattari, 2008a, p. 28. Refere-se ao corpo sem órgãos - CsO:

"O CsO é desejo, é ele e por ele que se deseja. Não somente porque ele é o plano de consistência ou o campo de imanência do desejo; mas inclusive quando cai no vazio da desestratificação brutal, ou bem na proliferação do estrato canceroso, ele permanece desejo."

${ }^{377}$ Merhy. 2007.
} 
Parece, então, que é justamente disto que se trata, como sintetiza Merhy nesta citação, de forma surpreendente: o campo da saúde, com a clínica ampliada, fazendo avançar a governamentalidade, com a regulamentação da vida, com a prescrição das formas de viver.

Para fazer frente a isto, restaria o cuidado, acoplado à clinica, pelo seu avesso, viabilizando a tragicamentalidade, produtora de vida ampliada e clínica restrita.

Tentarei então, pela descrição de mais dois acontecimentos terapêuticos, continuar avançando nesta discussão.

O relato desses acontecimentos terapêuticos tem ainda a pretensão de construir um testemunho fidedigno, como discutido na metodologia.

\section{Isadora}

Começo recordando que foi no começo de 2001 que Ivo me convidou para um chá da tarde em seu atelier, que ficava nas proximidades do CAPS, que nesta época era no bairro chamado Alto da Cruz, em Ouro Preto.

Eu já conhecia um pouco das fascinantes pinturas de Ivo, afinal um artista já consagrado e admirado por todos que o conheciam, era o senhor das cores estupendas, do casario de telhas e paredes vermelhas, com sua textura e volume carregados, de quem abraçou as espátulas e abandonou os pincéis; e visitar seu atelier, que ficava em sua própria casa era um verdadeiro presente.

Ivo tentava ser apenas um pacato senhor que ambicionava nada mais que realizar continuamente sua arte, que era inegavelmente vital para si, e vender alguns 
quadros que the permitissem saldar as contas e manter as despesas; mas seu espírito criativo lhe traía todo o tempo, forjando obras incríveis, capazes de criar uma intensa desterritorialização visual, nos fazendo ver aquelas velhas fachadas e sobrados de Ouro Preto de uma forma inteiramente nova e antes inimaginável, em suas cores gritantes.

Desta forma, o velho pintor que nas décadas anteriores havia desbundado e ido morar na amazônia, inicialmente a bordo de um barco, e depois nas terras de Alcântara; ao atracar em Ouro Preto, não dispunha de muita tranqüilidade, já que seu atelier era muito freqüentado por amigos, admiradores, aprendizes, marchants, artistas em busca de inspiração, e, a partir de 2001, um psiquiatra e uma acompanhante terapêutica.

É que, depois de apresentados por uma amiga em comum, e passados os primeiros instantes em que restei embevecido pelas obras nascentes naquela sala, em variados estágios de gestação, algumas apenas rabiscadas de carvão em tela, outras já a meio caminho do óleo em tela, algumas em retoque final; Ivo então me contou que havia um interesse bastante especial em me conhecer, e era o fato dele estar sabendo do trabalho que vínhamos desenvolvendo, havia pouco mais de um ano, na saúde mental de Ouro Preto.

Sua história era que estava vivendo um momento feliz em sua vida, com muita inspiração, produzindo e vivendo intensamente, morava com uma filha e um filho de seu terceiro casamento, mas trazia consigo uma frustração permanente, que era o fato de ter uma filha internada há vários anos em uma clínica psiquiátrica na cidade de Barbacena. 
Lamentava-se de que Isadora não estivesse compartilhando seus bons e demais momentos, e permanecesse isolada, deixando de viver sua juventude aqui fora, perdendo tantos anos em um lugar inútil.

Isadora estava então com vinte e sete anos, em contínuo tratamento psiquiátrico desde os doze anos de idade, quando iniciou com suas vivências de alucinações verbais e delírios fortemente persecutórios. Já havia sido tratada por inúmeros profissionais, em São Paulo, onde morava sua mãe, em Belo Horizonte, em Recife, onde nasceu, e também havia morado, em Ouro Preto, em Goiânia, e nos últimos anos em Barbacena.

Em sua peregrinação pela psiquiatria, Isadora havia feito uso de mais de vinte tipos de psicotrópicos, inúmeros neurolépticos, inclusive os chamados atípicos, como a risperidona, a clozapina, a olanzapina, havia sido tratada por vários e renomados profissionais, e submetida a dezenas de eletrochoques em vários hospitais, e há quatro anos havia sido submetida a uma psicocirurgia estereotáxica em Belo Horizonte, sem nenhuma melhora.

$E$, no entanto, a intervenção da saúde mental na cidade naquela época, foi suficiente para despertar naquele pintor, já sem dúvida com suas tendências incorrigivelmente aventureiras por trás de sua pacata delicadeza, a coragem de propor a alta de sua filha, desde que pudesse contar com nosso apoio constante e próximo.

Não havia como não aceitar a proposta, programamos sua saída gradual, passando cada vez períodos maiores em casa, com atendimentos semanais nos quais ela iria às consultas, além de participações em oficinas terapêuticas, uma visita minha, também semanal, para tomar um chá da tarde, em sua casa, e sentir o clima do convívio com os familiares, e a participação de uma acompanhante 
terapêutica, a qual estaria por perto algumas horas por dia, auxiliando no manejo de situações difíceis, saindo junto para freqüentar lugares pela cidade.

Em menos de um mês Isadora já estava morando com seu pai e seu meio irmão e sua meio irmã. Estes últimos eram mais jovens que ela, estavam dispostos a encarar o sacrifício de conviver com Isadora, mas não sem alguma relutância. O irmão, em particular, demonstrava pouco afeto por ela, além de uma certa preguiça diante do dever de ter de aceitá-la como ela é, com suas esquisitices, dizendo coisas por vezes bizarras, somado ao fato de que ele próprio, por sua vez, não andava nada bem, não conseguia avançar nos estudos secundários, já tendo dezenove anos, era usuário inveterado de maconha e crack, desde os onze anos, e freqüentemente estava envolvido em confusões com malandros, ou com a polícia ou com garotas de programa.

Conheci Isadora em um chá da tarde em sua casa, seu pai me apresentou como sendo seu novo psiquiatra, ao que ela, agitadamente, acolheu muito bem, me perguntando onde eu havia me formado, em qual faculdade, quantos anos tinha de vida profissional, se conhecia os doutores fulano e cicrano, se conhecia os juízes beltrano e tal, se conhecia as pessoas tais e tais, se conhecia seus parentes em São Paulo, se conhecia o senhor Silvestre, o enfermeiro que sua família chamava para levá-la à força para internação quando morava em São Paulo e entrava em crise.

Tentei responder alguma coisa, mas era logo interrompido pela torrente de sua fala apressada, era como se minhas respostas na verdade não tivessem nenhuma importância para ela, pelo menos naqueles primeiros momentos, eram as perguntas que importavam, que imperavam soberanas, ela precisava me perguntar milhões 
de coisas, e havia uma evidente urgência, uma pressão em sua fala, que jorrava sem parar, até que alguém colocasse uma vírgula, um basta, um agora já chega, interrompendo o fluxo, sob muitos e calorosos protestos.

Não era difícil de imaginar que o convívio em casa, logo nas primeiras semanas, já estava desgastando a todos, Isadora estava todo o tempo muito atabalhoada, falava excessivamente, comia também em excesso, e de uma forma acelerada, engolindo os alimentos. Seus belos traços estavam deformados pelo excesso de peso, pela estranha distribuição do tecido adiposo, alterada pelo uso crônico dos medicamentos; pelos movimentos estereotipados de membros e tronco, sempre esbarrando em tudo; pela dificuldade em higienizar-se adequadamente, em usar o banheiro sem fazer muita sujeira; pela forma tão estranha em vestir-se misturando as mais variadas roupas, cores e gêneros, pela maquiagem carregada e borrada.

A irmã e o irmão logo começaram a manifestar o constrangimento que ela muitas vezes criava para eles nos ambientes públicos que passou a freqüentar, além da falta de espaço e privacidade em casa, surgindo brigas freqüentes e episódios de agressividade física e verbal, colocando em dúvida a viabilidade de sua permanência em família.

Somava-se a isso a grande dificuldade que Ivo passou a ter para trabalhar, já que seu atelier era em sua própria casa, e ele buscava sempre um ambiente calmo para se inspirar e criar.

Os irmãos passaram então a ficar cada vez menos em casa, passando a maior parte do tempo na casa da mãe, que morava em outro bairro de Ouro Preto, e em suas atividades escolares e outras. Ivo, por sua vez, passou a produzir nas madrugadas (quando Isadora dormia sob efeito de intensos medicamentos), e dormir ao longo do dia, quando a 
mesma estava acordada. Neste momento, foi intensificada a presença da acompanhante terapêutica para seis horas diárias, com várias atividades fora de casa, entre oficinas e passeios, e sua medicação foi radicalmente modificada, com a suspensão de cinco classes psicotrópicas, e a aposta em um único neuroléptico, que já havia sido usado sem sucesso, segundo os relatos, mas sem informações sobre dosagens e tempo de uso.

Tal mudança nos medicamentos era uma aposta arriscada, a possibilidade da uma nova internação já se anunciava nas queixas da família, e a opção que fiz pela clozapina significava o risco grave de agranulocitose, aplasia de medula e até óbito se a uso não fosse interrompido a tempo, e isto significava ter que realizar hemogramas semanais durante longas dezoito semanas, com suas respectivas coletas e idas ao laboratório, que teriam que ser negociadas com Isadora.

Esta negociação não era nada fácil, Isadora dizia ser "anatruída", que significava "o contrário de nativa", e por isto havia sido vítima de uma terrível perseguição, que por sua vez incluía ter sido trocada por uma de suas inúmeras irmãs gêmeas com problemas mentais, e com isto Ihe atribuíram uma doença que com toda certeza ela não tinha, logo, ela estava sendo tratada e tomava remédios desnecessariamente, tudo era um grande "erro médico", e agora ainda iriam capturar seu sangue, com finalidades escusas, para entre outras coisas, poderem usar seu DNA e fazerem clones. Quanto à acompanhante terapêutica, esta era aceitável, porque "eu preciso de uma pessoa para guardar um segredo, pago para ela aturar o meu segredo e guiar meus passos."

Mas Isadora acabou aceitando, em grande parte devido à fundamental função transicional ou transitiva que 
a acompanhante terapêutica passou a exercer de forma cada vez mais importante, e também por receio de ser novamente internada, o que era seu grande pavor depois de passar cinco anos na clínica Nossa Senhora de Assunção, em Betim, muitos meses no Hospital Espírita André Luiz, em Belo Horizonte, um ano na clínica Bezerra de Menezes, em São Paulo, e por último, quatro anos na clínica Cecília Meireles, em Barbacena.

E os hemogramas foram chegando sempre normais, afastando o fantasma da agranulocitose, e a circulação de Isadora pela cidade foi ficando cada vez mais tranqüila. Também a aceitação das consultas e da minha presença foi se acomodando, não sem eventualmente ela me chamar de "otário" por "ser médico", porque ela soube que internei uma pessoa que ela conhece, ou, ainda, ela ameaçar me agredir ou agredir o pai fisicamente, ou chegar de fato a agredir a mãe quando esta, que morava em São Paulo, vinha visitá-la.

Em meados de 2002, Isadora já não aceitava mais freqüentar as oficinas terapêuticas do CAPS, afinal ela não tinha nenhuma doença mental que justificasse sua permanência com aquela turma. Mas isto não veio como um problema, mas como uma solução, um avanço, já que ela se propunha a freqüentar os cursos da FAOP - Fundação Artística de Ouro Preto, de desenho e pintura, e passava a pintar cada vez mais, em seu atelier, montado pelo seu pai, também em sua casa, mas independente do dele.

Em 2003 passa a viajar, em companhia de familiares ou da acompanhante terapêutica, para São Paulo, para praia, etc. Mantém a estabilidade nestes momentos, vencendo uma grande insegurança e temor dos familiares. Também enfrenta o desafio da saída de cada acompanhante terapêutica que a deixa, seja por outro trabalho, seja 
porque realmente não suportou a situação de estar tão próxima assim de Isadora, apesar de quase sempre, as acompanhantes terapêuticas estarem recebendo supervisão semanal do manejo situacional, e atendimento psicoterápico de suporte institucional.

Mas o grande desafio que Isadora teve de enfrentar, e o fez com um sucesso surpreendente, foi sem dúvida o falecimento de seu pai em 2004. Sua tranqüilidade no velório e no sepultamento de seu pai, seu comportamento pertinente diante de tudo aquilo e do que se seguiu, superou as melhores expectativas.

Sua irmã saiu de casa algum tempo depois da perda de seu pai, em seguida, seu irmão, que além do consumo estava também comercializando cocaína e derivados, foi preso em flagrante, inclusive com a invasão da polícia da casa de Isadora. E ela passou a morar sozinha, inicialmente ainda contando com a ajuda de uma acompanhante terapêutica, e depois apenas com uma empregada doméstica viabilizando os afazeres da casa.

A tudo isto Isadora respondeu, entre outras coisas, com várias exposições de seus quadros, com inúmeras vendas, com a formatura na FAOP, com o convívio amigável com a mãe, quando esta vinha lhe visitar, e quando desde 2008 passaram a morar juntas, e com consultas cada vez mais esparsas, necessitando cada vez menos de minha proximidade e do CAPS, definitivamente pedindo para não sequer comentarmos que ela faz tratamento em saúde mental, que dirá então de convidá-la para participações públicas como usuária da saúde mental.

Sua vivência claramente delirante é permanente, mas ela construiu um certo distanciamento que a permite lidar com as perseguições com menos sofrimento, com menos invasividade de sua vida, de sua existência, com 
uma preservação mínima de sua privacidade, de sua integridade, ainda que os perseguidores continuem fazendo as difamações, as sabotagens, as trocas de identidade, e ocasionalmente abusando de seu corpo, seja enquanto ela dorme, seja à distância, por um estranho mecanismo invisível, pelo qual eles têm acesso à sua intimidade mais secreta.

A presença de Isadora, que antes parecia tão destoante, incorporou-se à cidade, aos seus locais de freqüentação, apagando uma resistência, um sobressalto, uma ameaça que parecia pairar no ar com a sua chegada nos lugares. As pessoas realmente perderam o medo de que a qualquer momento ela falaria ou faria uma coisa completamente absurda.

Seu estilo muito próprio, e "retrô", de vestir-se em combinações surpreendentes, passou a ser associado muito mais ao seu estilo artisticamente exótico, do que ao patologicamente bizarro, ainda que ela tenha, até então, um talento apenas modesto, sem nenhum reconhecimento de genialidade, mas com a marca do criativo que ela delegou a si mesma.

Ora, o relato do acontecimento terapêutico de Isadora me parece particularmente representativo de duas posturas estéticas bem marcadas diante do trágico ao longo de seu périplo pelos tratamentos a que foi submetida.

Por um lado, temos uma postura que podemos chamar, por aproximação, de apolínea, por pretender um tratamento moral do trágico no sentido de purgá-lo, de eliminá-lo, de negá-lo, de subtraí-lo a qualquer custo. Afinal, ali onde o trágico se manifestava, plena e insistentemente, nas vivências delirantes terrivelmente persecutórias, alienígenas, nas vivênciasalucinatórias fortemente invasivas, tentou-se, em uma primeira fase de seu tratamento que vai 
dos doze aos vinte e sete anos, a amputação pela medicação massiva, pelo encarceramento, pela eletroconvulsoterapia repetitiva, pela cirurgia estereotáxica, que apesar de não portar a mesma brutalidade da lobotomia ou da leucotomia, compartilha dos mesmos princípios e pressupostos.

Por outro lado, encontramos a Segunda fase de seu tratamento, que vai de 2001 até o presente, e na qual podemos reconhecer uma outra postura estética que podemos chamar, ainda por aproximação, de trágica, no sentido de reconhecimento da inerência do trágico, ou de sua imanência, negando qualquer transcendência, não se confundindo com um "elogio da loucura", como elogio do trágico, mas, admitindo a presença indissociável do apolíneo e do dionisíaco; em um exercício de tolerância e validação das formas de existência, inclusive em suas dimensões também dionisíacas, e não apenas as apolíneas, buscando saídas, alternativas, soluções, alívios diante do terrível, mas recusando a função do aniquilador, do exterminador da dor de existir ao preço da perda da própria existência, e de sua legitimidade mesmo que trágica.

Cabe sublinhar ainda que, foi justamente a partir de um distanciamento do CAPS, um distanciamento do tratamento, um distanciamento da clínica -psiquiátrica, psicanalítica e psicossocial - que Isadora desenvolveu seu território de vida, cercada de várias medidas cuidadoras, como o acompanhante terapêutico, mas permitindo-se viver fora do circuito psi., que a mantinha refém há décadas.

Neste sentido, hoje a Fundação Artística de Ouro Preto - FAOP, lhe faz muito bem, mais do que o CAPS poderia, acredito. 


\section{Fritz}

Recebo no Centro de saúde Alcides Lins o processo referente ao caso de Fritz, há uma solicitação para que eu o visite, com urgência, pois seu domicílio está situado no epicentro da epidemia de dengue que assola o distrito sanitário nordeste e abarrota seus serviços de saúde com novos casos a cada dia.

Fritz já foi visitado por profissionais da equipe de saúde da família responsável por sua área, no bairro Cachoeirinha, em Belo Horizonte, e foi visitado também por profissionais do Centro de Referência em Saúde Mental Nordeste. Os técnicos servidores da zoonose também tentaram abordálo, devido aos problemas com ratos que a vizinhança vinha sofrendo, mas não tiveram muitos resultados; e técnicos da vigilância sanitária também estiveram lá, foram acionados devido ao mau cheiro que estaria incomodando vizinhos.

Pego meu carro e vou até sua casa nas proximidades da antiga fábrica Cachoeirinha, que deu origem ao bairro de mesmo nome. A fachada da casa apresenta algumas curiosidades, para dizer o mínimo. Uma porta de entrada foi bloqueada com uma parede irregular, não inteiriça de tijolos e concreto, e sobre esta porta há uma pequena sacada, que também foi bloqueada por um telhado que desce apoiando-se sobre o que seria o parapeito, vedando o espaço. Ao lado, o portão de garagem passou a ser a única entrada, mas também tem alguns tijolos concretados em sua base e laterais, como que para conter uma enxurrada que tentasse entrar por ali. No muro existem algumas plaquinhas de metal chumbadas, numa delas está escrito: "Propriedade particular desde 1966", em outra se pode ler: "telefone pré estelionato".

Aperto a campainha várias vezes, não parece emitir nenhum som, a aparência de abandono geral do local 
denuncia que deve estar desligada há anos, provavelmente por falta de energia elétrica. Tento bater no portão e chamá-lo pelo nome com insistência, dois cachorros me respondem lá de dentro com tal ânimo que só podem estar querendo dizer "vá embora e não volte mais aqui."

Apelo então para o vizinho da casa ao lado. Um solícito senhor me atende, e quando me identifico, sou convidado para entrar e esperar mais confortavelmente em sua casa, pois este vizinho supõe que Fritz tenha saído porque os cachorros estão fora, no quintal, e como o Fritz é imprevisível, não há como marcar um horário melhor para encontrá-lo.

Na verdade, ele anda muito, quase o dia todo e quase não está em casa, às vezes fica até alguns dias sem aparecer. Aceito o convite, até porque, enquanto espero, me parece que o vizinho tem muito a me dizer.

Ele me leva até uma simpática varanda nos fundos de sua casa, e desde ali podemos observar, de cima para baixo, toda a casa de Fritz, e o que a princípio parecia abandonado mostra-se agora como um cenário de completa ruína e desolação. Ninguém diria que estivesse habitada nos últimos anos, está literalmente caindo aos pedaços, e diferentemente das casas daqueles de poucos recursos, não se pode encontrar nenhuma estratégia de resistência a esta queda eminente.

O vizinho me conta que mora ali há poucos anos, mas que sabe que a casa está neste estado há uns dez anos, e que Fritz, apesar de receber uma gorda pensão que seu pai, um ex-combatente do exército alemão, Ihe deixou, vive ali sem água, luz, esgoto ou telefone. Explica que Fritz é advogado, tem conta no City Bank, um cofre cheio de dinheiro, carro na garagem, mobília refinada e objetos de valor, mas vive assim, sem tomar banho, coleta um pouco 
de água da chuva pelas calhas do telhado, e que dezenas de ratos circulam pelo quintal e pela casa a noite toda em grande alvoroço, que o mato cresce a esmo e vai tomando conta de tudo, e os cachorros se alimentam basicamente dos ratos.

O vizinho revela que ele mesmo faz tratamento psiquiátrico com o Dr Belisário, tomando remédios para "depressão", e que seu médico lhe sugeriu que mudasse dali, pois esta situação está Ihe fazendo mal, mas que prefere insistir em resolver este problema que já vem enfrentando há bom tempo, já tendo procurado o centro de saúde Cachoeirinha, o distrito sanitário nordeste, enviado e.mails para o prefeito, pedido ajuda a dois vereadores, sendo que um deles esteve no local.

O vizinho me conta ainda, que procurou a polícia, tendo sido feito vários boletins de ocorrência, e que denunciou a situação, e o descaso das autoridades, em jornais; que tem pedido ajuda em associação de bairro, etc; mas que até agora nada de concreto foi feito, persistindo o mal cheiro, o entulho, o matagal, e ele próprio e sua família já foram vitimados pela dengue.

Ele me confidencia ainda que já tentou falar com Fritz diversas vezes, que lhe ofereceu deixar uma mangueira por cima do muro para que ele pudesse usar a água sem precisar colocar latas para juntar a água da chuva, que sua cunhada que mora na Alemanha veio tentar conversar com ele também, mas que ele é muito truculento, responde sempre com agressividade, e que até matou o próprio irmão com quem morava, e quando sua mãe morreu ele ainda ficou com ela por três dias e que chegou a sair à rua com a mãe já morta, e agora não há mais nenhum parente dele a quem possam recorrer.

Quando peço que fale mais desta morte do irmão de 
Fritz, esclarece que este irmão tinha problemas mentais, os dois estavam no supermercado "Epa", Fritz agrediu o irmão como costumava fazer, este saiu correndo e atravessou a rua na frente dos carros, sendo atropelado e falecendo.

Depois de esperar algumas horas em nosso posto de observação eis que ouço barulhos na casa de Fritz e a porta se abrindo, ele na verdade estava em casa, e agora estava saindo, peço ao vizinho que me conduza rapidamente até a saída de sua casa e paro em frente ao portão de Fritz.

Os cachorros latem vigorosamente, espero que eles não saiam também, e felizmente Fritz sai sozinho trancando atrás de si o portão que retém os cachorros. Eu me apresento, lhe ofereço um boa tarde, digo que estou ali para saber como ele tem passado, se posso ajudá-lo em algo. Ele está com roupas imundas e uma sujeira impregnada Ihe compondo uma segunda pele, como se costuma ver em mendigos, tem um olhar assustado e vidrado, um rosto tão afilado que ressalta os zigomáticos, também a ossatura do tórax está realçada pela magreza, é mais alto que eu, de maneira que se dirige a mim falando e cuspindo de cima para baixo.

Diz então que não precisa de nada, que está muito bem, exceto por um problema de invasão de privacidade, ou melhor, invasão de particularidade, porque o privado e o particular não são a mesma coisa, me mostra, por exemplo, a plaquinha que chumbou no muro, nela está escrito propriedade particular e não propriedade privada.

Convido-o então para que venha ao centro de saúde Alcides Lins falar deste problema de invasão de particularidade, e que talvez possamos ajudá-lo de alguma forma. Ele retruca que seu irmão é que tinha problemas, e que ele o levava ao Alcides Lins, e que não ajudou em nada, ele acabou morrendo tragicamente, e que ele certamente 
não irá porque não precisa de nada disso que ofereço, que já foi feliz naquele lugar e que poderia continuar a sê-lo não fosse a invasão de particularidade e a supressão de planta construída.

Peço que me explique isto, ele pergunta se aquele diante de sua casa é meu carro, digo que sim, ele anota a placa e pede que eu o siga, damos a volta no quarteirão, ele me mostra um muro no qual está escrito Pizzaria, ele me diz: "está vendo este muro cor de rosa, este portão com um buraco, era um bar, uma boate, ficava cheio a noite toda, era a noite toda fazendo barulho, e eles sabiam que meu irmão tinha problemas, e aqui é uma área residencial, não pode ter este tipo de coisa, e este aqui do lado é meu muro, os fundos da minha casa, coloquei estes tijolos para ninguém confundir."

Vamos voltando para frente de sua casa e ele vai me dizendo: "está vendo aqui, também tem um muro rosa, invasão de particularidade, e esta casa aqui da esquina, tá vendo, tinha um quarto ali acima, é supressão de planta construída, e ali na outra esquina tem uma casa de dois andares está vendo, começa dali a supressão de planta construída, já reclamei na prefeitura, e aqui, esta entrada era entrada da parte de trabalho e ali entrada da parte residencial, é que eu trabalho com estamparia têxtil, e meu hobby é mecânica, porque estamparia têxtil é diferente de mecânica, ali o hobby e aqui trabalho. A supressão de planta construída vai acabar com tudo, eu vou mudar daqui, não vou morar mais aqui...agora tenho que ir, estou ocupado."

Ofereço ainda uma vez que apareça no Alcides Lins para conversarmos sobre estes problemas de supressão de planta construída e invasão de particularidade. Ele diz: "Alcides Lins, lá no bairro Renascença? Eu levava meu irmão lá, eu não vou lá não, te agradeço, mas não irei lá não, eu vou mudar daqui, com licença (...)" 
Vou embora então, e espero por uma mínima possibilidade de que ele apareça no centro de saúde, o que acaba não acontecendo.

Volto a sua casa outras vezes tentando um novo encontro, mas não tenho a mesma sorte da primeira vez, sequer o vejo, ou saiu, ou refugia-se em casa.

O distrito sanitário me convoca para uma reunião, quer que eu resolva o problema o mais rápido possível, pois os vizinhos estão reclamando da incompetência das autoridades responsáveis. Questionam se eu não deveria ter emitido uma guia de internação no dia que estive com ele. Alego que era um primeiro encontro, que ele estava cooperativo e me recebeu bem, e que conversamos de forma até tranqüila. Peço mais um tempo para tentarmos novas aproximações, novas estratégias de abordagem.

Mas o distrito não quer saber de muita conversa, meu relatório não coincide com os relatos de hostilidade dos outros agentes da segurança pública, e ele ter sido cooperativo comigo não combina com o que esperavam.

Tento novamente uma aproximação sem sucesso, ele não pára mais em casa no horário de trabalho dos servidores da prefeitura, evita nos encontrar.

Pela sua ficha no centro de saúde, onde já esteve poucas vezes e há anos atrás, devido às viroses, sobretudo dengue, fico sabendo que ele provavelmente deve ser cidadão alemão.

Entro em contato então com o consulado da Alemanha em Belo Horizonte, para tentar alguma ajuda. Explico a situação para a secretária do honorável cônsul, na esperança de que talvez eles consigam localizar algum parente, ainda que distante, do Fritz, pois se trata de um cidadão alemão abandonado em uma situação de profunda 
precariedade.

Mas, para minha surpresa, assim que começo a contextualizar a situação para a secretária, antes mesmo de ter falado seu nome, ela me pergunta: "é do Fritz que você está falando?"

Pego de surpresa, confirmo ser essa a pessoa em questão, e que já facilitava as coisas o fato dela conhecê-lo. Ela então me conta que ele já havia ido lá, no consulado, muitas vezes, que a visitava, falava um pouco em alemão, levava algumas coisas para deixar lá, pois achava ser um lugar mais seguro que sua casa, que sempre era muito cordial, mas que pelo seu jeito estranho e pela sua sujeira, ela havia percebido que ele provavelmente deveria ter problemas mentais, e que ele sempre demonstrava o maior respeito pelo honorável cônsul.

Explico então para a secretária que há indícios de que o Fritz esteja adoecendo naquela situação, e do campo de guerra que está se tornando sua vizinhança, e que ele não admite ser tratado, ser medicado, ser acompanhado; mas que, certamente aceitaria se ouvisse esta recomendação vinda do cônsul.

A secretaria se prontifica em ajudar, que certamente falará ao cônsul, e que ele por sua vez, sendo uma pessoa muito boa, se disponibilizará em colaborar pela ajuda de um cidadão alemão.

No dia seguinte, porém, sou convocado pela coordenação regional da zoonose, é que a prefeitura declarou guerra contra a dengue, e ela é responsável pela área nordeste, e me mostra um mapeamento que denuncia que, no entorno da casa do Fritz, não conseguem impedir a persistência do mal. Irão invadir a casa, sendo, claro, uma boa oportunidade para que eu proceda o internamento do Fritz, se quiser aproveitar a ocasião. 
Digo então que aquilo não poderia ser daquele jeito, que estava avançando nas estratégias de abordagem do caso, que já tínhamos feito contato com o consulado, e também com uma pessoa que já havia trabalhado na casa, há anos atrás, quando sua mãe ainda era viva, e que ele provavelmente aceitaria o tratamento desta forma.

Sem sucesso com a tenente da guerra contra a dengue, tentei novamente o consulado, mas a secretária me informa que o Fritz ainda não havia aparecido por lá, e o cônsul, por sua vez, mesmo sendo uma pessoa muito boa, estava sem disponibilidade para ir até a casa do Fritz.

A casa de Fritz é invadida, e antes mesmo de começar a operação, assustado com a movimentação, ele foge, com destino desconhecido. A zoonose, apoiada pela SLU, serviço de limpeza urbana, faz uma limpeza geral de sua casa, com capina e remoção de entulho e lixo, atacando todos os focos de resistência da dengue.

Passam alguns meses, Fritz ainda não voltou em sua casa, ninguém tem notícias dele, também no consulado, que freqüentava, não voltou mais, não foi visto na vizinhança, as agentes comunitárias de saúde que o conheciam e sabiam por onde ele costumava andar, não o viram mais.

Ninguém possuía uma foto sua, para que fosse colocada na lista de desaparecidos; a polícia foi comunicada, um vizinho ouviu falar que ele teria mudado para outro bairro, em outra região de Belo Horizonte.

Esta história me parece particularmente reveladora do lugar habitualmente atribuído aos trabalhadores da saúde mental, no conjunto dos funcionários da segurança pública, a serviço da governamentalidade.

O curioso é que, não tendo tido oportunidade de desenvolver um trabalho terapêutico com ele, que estaria 
inserido na governamentalidade, não pude agir pela tragicamentalidade também. A oportunidade de produzir cuidado fora da clínica, em geral caminha acoplada ao trabalho clínico propriamente dito.

É importante insistir que estamos aqui bem longe do elogio da tragédia, que insinuaria um gozo perverso, que se regozija à custa destas vidas, que nos tocam participar de seus acontecimentos terapêuticos.

Trata-se, isto sim, ao contrário de qualquer encantamento com a tragédia alheia, de uma busca de produção de cuidado, que aceita as dimensões apolínea e dionisíaca que compõem a vida, e que não dispõe de grandes inovações tecnológicas, a não ser desta tecnologia leve, da qual os encontros poderiam estar sempre prenhes, e desta postura estética decidida pela vida mais próxima do que ela pode, a tragicamentalidade. 


\section{VI - Conclusão}

No entanto, trabalhar, é conseguir pensar algo que não seja o que se pensava antes.

M. Foucault

Tudo tem sua curva

Raiz de lótus, que cresce na água

Desviando de peixe

Batata doce, que cresce na terra

Desviando de pedra Rio, que cresce no campo Desviando de flor Vôo de andorinha, que cresce no ar

Desviando de vento Pensamento, que cresce na gente Desviando de certezas

Ricardo Luiz Narciso Moebus

A tentativa que esbocei até aqui de refletir sobre a produção do cuidado em saúde mental, a partir do binômio governamentalidade/tragicamentalidade, mais do que exercício teórico, é algo que vem se produzindo como uma inevitável e incortornável secreção de toda minha dedicação ao trabalho da produção do cuidado, em meio ao 
meu encontro contínuo e irrevogável de ser eu mesmo um operador ou operário da produção do cuidado em saúde mental.

Declaro aqui este exercício de dar passagem a muitas e tantas vozes que me habitam pela força deste exercício de produzir cuidado, de tal maneira que, se não o faço, não sinto ter cumprido com missão de dar voz e vez a tantos afetos compartilhados comigo, de forma frequentemente dolorosa, quase sempre depositando uma confiança e uma disponibilidade de compartilhamento que preciso estar à altura de fazer jus aos mesmos.

Com isto constato, portanto, a necessidade de compartilhar, e não apenas, mas transitar estas vozes tantas que pedem passagem sob os suplícios de muitos que acompanhei em suas crises, em especial aqueles reconhecidos de uma forma geral, na racionalidade classificatória nosográfica, como psicóticos:

"O que abrange o termo psicose no domínio psiquiátrico? Psicose não é demência. As psicoses são, se quiserem - não há razão para se dar ao luxo de recusar empregar este termo -, o que corresponde àquilo a que se chamou, e a que legitimamente continua se chamando, as loucuras." 378

Desta forma, vou me aproximando da conclusão de que este esforço em construir um conceito ferramenta, a tragicamentalidade, tem por horizonte, principalmente ser operativo na prática da produção do cuidado com os psicóticos, diante de suas crises, diante de suas vivências tão indescritíveis e por vezes assustadoras, e, no entanto, compartilhadas generosamente, diuturnamente, com os operários da produção do cuidado, em tantos e variados serviços de saúde mental.

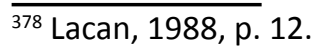


Talvez seja uma conclusão excessiva e temerária dizer aqui que este exercício realizado de buscar e rastrear neste autor colossal, Nietzsche, muito além das minhas possibilidades de acompanhar seus intrincados e sofisticados pensamentos, muito além das minhas limitadas formações para enxergar suas vastas conexões e referências - que reescrevem parte considerável da história da filosofia ocidental -, e mesmo assim, tenho eu por conclusão, que retirei de suas folhas um extrato fitoterápico, para que possa combater uma peste que assola, de maneira epidêmica nesses tempos em que vivemos, os que se dedicam ao trabalho em saúde mental.

Este extrato é a tragicamentalidade, conceito ferramenta que traz para a cena da produção do cuidado sua dimensão trágica, no sentido Nietzschiano, da pluralidade e multiplicidade do humano que não se deixa esgotar e resumir ao império da razão.

Um extrato que permite o combate pestilífero de uma por outra peste, pois não se extrai desta obra um remédio para remediar nada, mas extraio uma peste que possa contrapor-se a tantas outras, que possa contrapor-se a tantas pestes racionalizantes, tecnocráticas a serviço da governamentalidade.

Governamentalidade que exige, a cada dia, a submissão, a regulamentação de todas as formas de vida por suas legislações, em nome da razão, da função, do pragmatismo; com todas as suas tecnologias maravilhosas que produzem muito alívio e bem estar, como não se pode deixar de reconhecer, mas que tem cobrado o preço alto do empobrecimento das pretensões de viver.

Com a antiga lógica da similitude no combate, contraponho contra o neopragmatismo e outras pragas ou neopragas, o ressurgimento de antiga peste que 
dormita encapsulada nos sonhos mirabolantes dos que anseiam viver uma vida que possa ser mais que prática, dos que não apenas não toleram viver de joelhos, mas não suportam apenas andar a vida, ou não apenas ampliar suas possibilidades de andar a vida, mas nasceram com pernas suficientemente inquietas para dançar a vida.

Podemos remediar estas pernas inquietas, corações sobressaltados, almas turbulentas por serem turbinadas, já temos tecnologia e já avançamos o suficiente na ciência para podermos empalidecer todas as cores fortes e intensas que desatinam o quadro humano. Estamos prontos para um homem empastelado, em tons pastéis, o homem pastel, assado, sem sal e com pouca gordura, com recheio devidamente calculado, está pronto.

Toda uma larga equipe asséptica põe a mão na massa nesta pastelaria, a única coisa vibrante que resta são as asas das moscas que trouxemos para cá, uma perigosa mosca com suas asas vibrantes pode com suas patas sujas fazer desandar a massa, é isto que trago e fui buscar nas estranhas entranhas de Nietzsche e Foucault.

Desde quando surgiu tanto incômodo em mim com esta prática pasteurizada e pasteurizante, realmente não sei, mas posso recordar um ponto marcante. É que ao longo duas décadas trabalhando nos serviços de saúde pública em Belo Horizonte e em Ouro Preto, seja em CAPS ou em Centro de Saúde, foram várias as vezes que fui agredido, diretamente, ou indiretamente, através por exemplo de meu carro.

Bem, poderia facilmente lidar com estes eventos como uma casualidade, alguém querendo roubar alguma coisa e aleatoriamente escolhendo meu carro, ou poderia tomar isto como uma pequena injustiça, já que era enquanto trabalhava, me dedicando a ajudar aquelas pessoas, que 
acabei agredido. Ou poderia ainda perceber isto como algo bem pessoal, já que eu estava ali, como representante em exercício de uma governamentalidade em ato, pretendendo estabelecer ou determinar formas de vida.

Sendo assim, será que, quem me atacava, poderia estar atacando também, desta forma, toda a prática discursiva estabelecida entorno de certa governamentalidade em voga neste momento que vivemos?

Ora, é por aí que insiste, em mim, a pergunta se seria possível estar na produção do cuidado em ato, sem produzir necessariamente só governamentalidade, ou, produzindo outra coisa para além desta governamentalidade, criando um tensionamento interno, um paradoxo, um cuidado controverso, portador de tragicamentalidade na dobra da governamentalidade, como processos ambíguos, ou, melhor seria dizer anfíbios, portadores de duas vias biopolíticas. Uma biopolítica, na concepção original de Michel Foucault, como exercício de uma governamentalidade sofisticada na produção de certas formas de vida funcionalmente vinculadas a um neoliberalismo configurador da vida como empresa, empreendimento financeiro, capital humano; e, ao mesmo tempo, nesta formação de anfíbios, uma biopolítica da vida como política e estética da produção de si, da disputa por um pertencimento a si mesmo, exercício de tragicamentalidade.

É isto, portanto, que chego a dizer, que sendo a saúde pública, a Medicina em geral, ou a medicina mental em particular, portadora de uma tensão constitutiva irredutível, com suas clínicas, uma prática discursiva primordialmente produtora de governamentalidade, que possa ser também, na produção do cuidado, produtora de tragicamentalidade, dimensão estética do agir em saúde, dimensão microbiopolítica capaz de produzir, com o cuidado, anfíbios. 
Insistindo sobre este ponto, ou adiando ainda um pouco o ponto que seja final aqui, digo por fim que, sendo afinal a clínica, com todas suas maravilhosas tecnologias, formas sofisticadas a serviço da governamentalidade, porém trazendo sempre em suas franjas, não como desdobramento, mas antes como um rebatimento em dobra, o cuidado; concluo então que, falar da tragicamentalidade, como possível rebatimento da governamentalidade, é, acima de tudo, um esforço para dar visibilidade ao par equivalente, da produção do cuidado como possível rebatimento em dobra da clínica. Seja ela psiquiátrica, psicanalítica, psicossocial ou outras tantas.

A tragicamentalidade como dobra irredutivel à governamentalidade, trata-se do cuidado como dobra irredutível à clínica. Resistência pode ser aqui uma última palavra?

Acredito que não, não tenho e não posso ter a última palavra em absolutamente nenhum dos assuntos, pelos quais me aventurei, possivelmente de forma imperfeita, tosca, imprecisa.

Só posso trazer uma palavra primeira, ou segunda, ou terceira; resistência, palavra que abre, legado de Foucault, como Nietzsche, desbravador de trilhas, semeador de caminhos, chaveiro, ensinador de reveses.

Fechamentos? Já os temos em excesso, resistência pode servir aqui para ainda mais abrir, ainda mais devir.

“(...) é possível suspeitar que haja uma certa impossibilidade de construir hoje uma ética do eu, quando talvez seja esta uma tarefa urgente, fundamental, politicamente indispensável, se for verdade que, afinal, não há outro ponto, primeiro e último, de resistência ao poder político senão na relação 
de si para consigo." ${ }^{379}$

Tragicamentalidade, lanço esta seta na produção do cuidado, vejo jorrar uma dimensão estética do agir em saúde, com suas possibilidades, estética socrática, estética apolínea, estética do trágico, dionisíaco-apolínea, estética da existência.

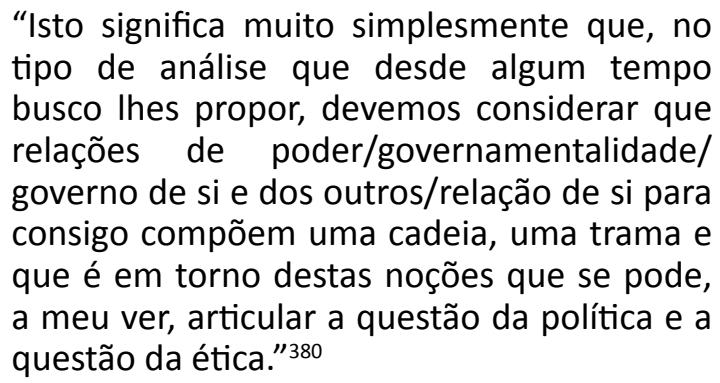

Tragicamentalidade, uma noção, uma questão, uma visão, uma di-visão dentro da governamentalidade que opera em ato no agir das clínicas psiquiátrica, psicanalítica, psicossocial e outras mais.

Tragicamentalidade/governamentalidade que habitam o trabalho vivo em ato na produção de saúde e cuidado, sublinhando ainda mais a tensão que lhe é constitutiva e inerente.

Tragicamentalidade/governamentalidade que informam uma microbiopolítica, estética operante nos caminhos de composição da vida.

$\overline{379}$ Foucault, 2004, p. 306.

380 Ibidem, p. 307. 



\section{VII - Referências}

AGAMBEN, Giorgio. Homo Sacer - O poder soberano e a vida nua I. Belo Horizonte: Editora UFMG, 2007.

AMARANTE, Paulo. A (Clínica) e a Reforma Psiquiátrica. In: Archivos de Saúde Mental e Atenção Psicossocial. Rio de Janeiro: Editora Nau, 2003c.

- Loucos pela Vida: a trajetória da Reforma Psiquiátrica no Brasil. Rio de Janeiro: ENSP/FIOCRUZ, 2003b. . O Homem e A serpente - Outras Histórias Para a Loucura e a Psiquiatria. Rio de Janeiro: Editora Fiocruz, 2003a.

AMARANTE, Paulo (org.). Psiquiatria Social e Reforma Psiquiátrica. Rio de Janeiro: Editora Fiocruz, 1994.

AMERICAN PSYCHIATRIC ASSOCIATION. Critérios Diagnósticos do DSM- IV. Porto Alegre: Artes Médicas, 1995.

ARISTÓTELES. Arte Poética. São Paulo: Martin Claret, 2007. ARRUDA ARANHA, M. Lúcia; PIRES MARTINS, M. Helena. Filosofando - introdução à filosofia. São Paulo: Moderna, 1986.

BADIOU, Alan. Ética: Um Ensaio Sobre a Consciência do Mal. Rio de Janeiro: Relume-Dumará, 1995. 
BARRETO, F. P. Reforma Psiquiátrica e Movimento Lacaniano. Belo Horizonte: Editora Itatiaia, 1999.

BARROS CONDE RODRIGUES, Heliana. À Beira da Brecha: Uma História da Análise Institucional Francesa nos Anos 60, In: Ensaios: Subjetividade, Saúde Mental, Sociedade. Rio de Janeiro: Editora Fiocruz, 2000.

BERCHERIE, Paul. Os Fundamentos da Clínica - História e Estrutura do Saber Psiquiátrico. Rio de Janeiro: Jorge Zahar. Editor, 1989.

BOAL, Augusto. Teatro do Oprimido e Outras Poéticas Políticas. Rio de Janeiro: Civilização Brasileira, 1991.

BRASIL. Ministério da Saúde. Legislação em Saúde Mental. Brasília: Editora MS, 2004a.

BRASIL. Ministério da Saúde. Saúde Mental no SUS: Os Centros de Atenção Psicossocial. Brasília: Editora MS, 2004b.

CALLIGARIS, Contardo. Introdução a uma Clínica Diferencial das Psicoses. Porto Alegre: Ed. Artes Médicas, 1989.

CAMPOS, Gastão Wagner de Souza e AMARAL, Márcia Aparecida. A clínica ampliada e compartilhada, a gestão democrática e redes de atenção como referenciais teóricooperacionais para a reforma do hospital. Ciência e saúde coletiva, Rio de Janeiro, v.12, n.4, July/Aug. 2007. Disponível em:: $\quad$ http://www.scielo.br/scielo.php?pid=S1413$81232007000400007 \&$ script=sci_arttext\&tlng=pt. Acesso em: 24 fev 2011.

CARVALHO, F. Z. F.; MILAGRES, A. F. A Clínica do Cersam. In: Metipolá - Revista do Cersam Leste. Belo Horizonte: Secretaria de Saúde, 1997.

CASTRO, Edgardo. Vocabulário de Foucault: um percurso pelos seus temas, conceitos e autores. Belo Horizonte: Autêntica Editora, 2009. 
CECÍLIO, L. C. O. ; MENDES, T. C. Propostas alternativas de gestão hospitalar e o protagonismo dos trabalhadores: por que as coisas nem sempre acontecem como os dirigentes desejam? In: CERSAM/LESTE. Proposta Para o Centro de Referência em Saúde Mental Distrito Sanitário Leste. Belo Horizonte: Mimeo, 1996.

CHAVES, Ernani. Nas Origens do Nascimento da Tragédia. In: NIETZSCHE, Friedrich. Introdução à Tragédia de Sófocles. 243. O trágico na produção do cuidado. Rio de Janeiro: Jorge Zahar, 2006.

COHN, Sérgio ; PIMENTA, Heyk. Maio de 69. Rio de Janeiro: Azougue, 2008.

COOPER, David. Psiquiatria e Antipsiquiatria. São Paulo: Perspectiva, 1973.

COSTA, Jurandir Freire. Apresentação. In: Clínica da Psicose: Um Projeto na Rede Pública. Rio de Janeiro: Te Corá Editora, 1996.

COSTA-ROSA, Abílio, LUZIO, Cristina A., YASUI, Sílvio. Atenção Psicossocial: rumo a um novo paradigma na Saúde Mental Coletiva. In: Archivos de Saúde Mental e Atenção Psicossocial. Rio de Janeiro: Editora Nau, 2003.

. O Modo Psicossocial: Um Paradigma das Práticas Substitutivas ao Modo Asilar, In: Ensaios: Subjetividade, Saúde Mental, Sociedade. Rio de Janeiro: Editora Fiocruz, 2000.

DALGALARRONDO, P. Civilização e Loucura - Uma introdução à história da etnopsiquiatria. São Paulo: Editora Lemos, s/d.

DELEUZE, Gilles. Conversações. São Paulo: Ed. 34, 2007.

. Crítica e Clínica. São Paulo: Ed. 34, 2006.

. Gilles. Espinosa - Filosofia Prática. São Paulo:

Escuta, 2002. 
DELEUZE, Gilles ; GUATTARI, Félix. Mil Platôs. São Paulo: Ed. 34, 2008a. v.3.

. Mil Platôs. São Paulo: Ed. 34, 2008. v.5.

. O que é a Filosofia? Rio de Janeiro: Ed. 34, 2009.

DOMINGUES, I. O Grau Zero do Conhecimento-O Problema da Fundamentação das Ciências Humanas. São Paulo: 244 Edições Loyola, 1991.

DOR, Joel. Estruturas e Clínica Psicanalítica. Rio de Janeiro: Taurus - Timbre, 1991.

DOS ANJOS, Cyro. O Amanuense Belmiro. Belo Horizonte, Rio de Janeiro: Livraria Garnier, 2000.

ESPINOSA, Baruch. Ética - Demonstrada à Maneira dos Geômetras. In: Espinosa São Paulo: Abril Cultural, 1983. (Coleção Os Pensadores).

ESQUIROL, J.E.D. Memorias Sobre La Locura y sus Variedades. Madrid: Ediciones Dorsa, 1991.

ESTELLITA-LINS, Carlos Eduardo. Notas Sobre Criação e Desrazão em uma Certa Experiência trágica da Loucura. In: Ensaios: Subjetividade, Saúde Mental, Sociedade. Rio de Janeiro: Editora Fiocruz, 2000.

EWALD, François; FONTANA, Alessandro. Prefácio. In: Em Defesa da Sociedade. São Paulo: Martins Fontes, 2005.

EY, Henri. Manual de psiquiatria. Rio de Janeiro: Masson, 1981.

FERREIRA, Aurélio Buarque de Holanda. Novo dicionário Aurélio da Língua Portuguesa. Rio de Janeiro: Nova Fronteira, 1986.

FIGUEIREDO, L. C. A Invenção do Psicológico - quatro séculos de subjetivação 1500-1900. São Paulo: Ed. Escuta/ Educ, 1994. 
FIRMINO, H. Nos Porões da Loucura. Rio de Janeiro: Editora Codecri, 1982.

FOUCAULT, Michel. Os Anormais. São Paulo: Martins Fontes, 2001.

. Ditos e Escritos - Ética, Sexualidade, Política. Rio de Janeiro: Forense Universitária, 2004. 2004a. v.5

. Doença Mental e Psicologia. Rio de Janeiro: Editora Tempo Brasileiro, 1984.

. Em Defesa da Sociedade. São Paulo: Martins Fontes, 2005.

A Hermenêutica do Sujeito. São Paulo: Martins Fontes, 2004.

. História da Loucura. São Paulo: Editora Perspectiva, 1987.

. História da Sexualidade 1-A Vontade de Saber. Rio de Janeiro: Ed. Graal, 1988.

. História da Sexualidade 2 - O Uso dos Prazeres. Rio de Janeiro: Edições Graal, 1988.

Os Intelectuais e o Poder. In: Ditos \& Escritos. Rio de Janeiro: Forense Universitária, 2006c. v.4.

. Microfísica do Poder. Rio de Janeiro: Edições Graal, 2001a.

. O Nascimento da Biopolítica. São Paulo: Martins Fontes, 2008b.

. O Nascimento da Clínica. Rio de Janeiro: Ed. Universitária, 2003.

- Omnes et Singulatim: uma Crítica da Razão Política. In: Ditos \& Escritos. Rio de Janeiro: Forense Universitária, 2006b. v.4. 
1996.

. A Ordem do Discurso. São Paulo: Edições Loyola,

. O Poder Psiquiátrico. São Paulo: Martins Fontes,

$2006 a$.

. Resumo dos Cursos do Collège de France (1970

- 1982). Rio de Janeiro: Jorge Zahar, 1997.

. Segurança, Território, População. São Paulo: Martins Fontes, 2008a.

.. Vigiar e Punir - Nascimento da Prisão.

Petrópolis: Vozes, 2002.

FREUD, Sigmund. "Fragmento da análise de um caso de Histeria”, 1905 [1901]. Edição Standard Brasileira das Obras Psicológicas Completas de Sigmund Freud. Rio de Janeiro: Imago Editora, 1989.

."Análise de uma fobia em um menino de cinco anos", 1909. Edição Standard Brasileira das Obras Psicológicas Completas de Sigmund Freud. Rio de Janeiro: Imago Editora, 1989.

. "Notas sobre um caso de neurose obsessiva", 1909. Edição Standard Brasileira das Obras Psicológicas Completas de Sigmund Freud. Rio de Janeiro: Imago Editora, 1989.

"Notas psicanalíticas sobre um relato autobiográfico de um caso de Paranóia (Dementia Paranoides)", 1911. Edição Standard Brasileira das Obras Psicológicas Completas de Sigmund Freud. Rio de Janeiro: Imago Editora, 1989.

. "História de uma Neurose Infantil", 1918 [1914]. Edição Standard Brasileira das Obras Psicológicas Completas de Sigmund Freud. Rio de Janeiro: Imago Editora, 1989. 
FUGANTI, Luiz. Biopolítica e produção de saúde - um outro humanismo? Vitória, 2008. Disponível em: http:// escolanomade.org/textos/fuganti-luiz/biopolitica-eproducao-de- saude-um-outro-humanismo. Acesso em: 24 fev 2011.

. Saúde, desejo e pensamento. São Paulo: Editora HUCITEC, 2008a.

GABBARD, Glen O. Tratamento dos Transtornos Psiquiátricos. Porto Alegre: Artmed, 2009.

GARCIA, Célio. Psicanálise, Psicologia, Psiquiatria e Saúde Mental - Interfaces. Belo Horizonte: Ophicina de Arte e Prosa, 2002.

GOFFMAN, E. Manicômios, Prisões e Conventos. São Paulo: Editora Perspectiva, 1996.

GOLDBERG, J. Clínica da Psicose - Um projeto na rede pública. Rio de Janeiro: Te Cora Editora, 1996.

GUATTARI, Félix. Caosmose - Um Novo Paradigma Estético. São Paulo: Ed. 34, 1992.

GUIMARÃES ROSA, João. Primeiras Estórias. Rio de Janeiro: Editora Nova Fronteira, 1988.

JASPERS, Karl. Psicopatologia Geral - Psicologia Compreensiva, Explicativa e Fenomenologia. Rio de Janeiro: Livraria Atheneu, s/d.

JONES, Maxwell. A Comunidade Terapêutica. Petrópolis: Vozes, 1972.

KAPLAN, Harold I.; SADOCK, Benjamin J. Compêndio de Psiquiatria. Porto Alegre: Ed. Artes Médicas, 1990.

LACAN, Jacques. O Seminário - Livro 17 - o avesso da psicanálise. Rio de Janeiro: Jorge Zahar, 1992.

.. O Seminário - Livro 3 - as psicoses. Rio de Janeiro: Jorge Zahar, 1988. 
LALANDE, A. Vocabulário Técnico e Crítico da Filosofia. São Paulo: Ed. Martins Fontes, 1993.

LANCETTI, Antônio. Clínica Peripatética. São Paulo: Editora HUCITEC, 2006.

LOBOSQUE, A. M. Clínica em Movimento - Por uma Sociedade sem manicômios. Rio de Janeiro: Editora Garamond, 2003.

. Pelo Fim Próximo do Hospital Psiquiátrico. In:

Urgência Sem Manicômio. Belo Horizonte: Secretaria Municipal de Saúde, 1994.

LOPEZ, Mário ; LAURENTYS, J. M. Semiologia Médica. Rio de Janeiro: Ed. Livraria Atheneu, 1990.

MACHADO, Roberto. Introdução - Por uma genealogia do poder. In: Microfísica do Poder. Rio de Janeiro: Edições Graal, 2001.

- O Nascimento do Trágico - De Schiller a Nietzsche. Rio de Janeiro: Jorge Zahar Ed., 2006.

MAGALHÃES, Christine Vianna Algarves. Arte Terapia. Revista Olympia - Cadernos de Saúde Mental de Ouro Preto, Ouro Preto, v.1, n. 1, ago. 2004.

. Nietzsche e a Polêmica Sobre o Nascimento da Tragédia. Rio de Janeiro: Jorge Zahar Ed., 2005.

MARTINS, André. Criação e Psicose: Refazendo a Metapsicologia das Psicoses. In: Ensaios: Subjetividade, Saúde Mental, Sociedade. Rio de Janeiro: Editora Fiocruz, 2000.

MARX, Karl. O Capital - Crítica da Economia Política. Livro I - Vol. 1-O Processo de Produção do Capital. Rio de Janeiro: Civilização Brasileira, 2004.

MERHY, E. E. $\mathrm{O}$ ato de cuidar como um dos nós críticos 'chaves' dos serviços de saúde. Campinas: 1999a. Disponível 
em: <http://www.uff.br/saudecoletiva/professores/ merhy/>. Acesso em: 24 fev 2011.

O ato de cuidar: alma dos serviços de saúde? Campinas: 1999. Disponível em: <http://www.uff.br/ saudecoletiva/professores/merhy/>. Acesso em: $24 \mathrm{fev}$ 2011.

. Os CAPS e seus Trabalhadores: No Olho do Furacão Antimanicomial. Alegria e Alívio como Dispositivos Analisadores. Campinas, 2004b. In: HYPERLINK .Disponível em:http://www.paginas.terra.com.br/saude/merhy. Acesso em: 24 fev 2011.

- O Conhecer Militante do Sujeito Implicado: O Desafio em Reconhecê-lo Como Saber Válido. In: FRANCO, T. B. et al. Acolher Chapecó - Uma experiência de mudança do modelo assistencial, com base no processo de trabalho. São Paulo:

HUCITEC, 2004a.

. Em Busca do Tempo Perdido: A Micropolítica do Trabalho Vivo em Ato, em Saúde. In: Agir Em Saúde: Um Desafio Para o Público. São Paulo: HUCITEC, 2006.

- Gestão da produção do cuidado e clínica do corpo sem órgãos: novos componentes dos processos de produção do cuidado em saúde. 2007. In: HYPERLINK. Disponível em: http://www.paginas.terra.com.br/saude/ merhy. Acesso em: 24 fev 2011.

- Realizar no Micro a Luta Macro - O Ato de Cuidar, Um Agir Tutelar e Autonomizador. COBREM: 2001. Disponível em: www.paginas.terra.com.br/saude/merhy. Acesso em: 24 fev 2011.

- Saúde - a cartografia do trabalho vivo. São Paulo: HUCITEC, 2002.

MOEBUS, R. Chaves Para Uma Cadeia Discursiva - 
Considerações Sobre Sexologia a Partir de Michel Foucault. Olympia - Cadernos de Saúde Mental de Ouro Preto, Ouro Preto, v.1, n.1, 2004.

. O Tratamento Involuntário em Ato de Delicadeza. Dissertação de mestrado em clínica médica, defendida na Universidade Federal do Rio de Janeiro, 2008. NICÁCIO, M. F. Da Instituição Negada À Instituição Inventada. In: LANCETTI, Antônio et al. Saúde Loucura 1. São Paulo: Editora HUCITEC, 1989.

NIETZSCHE, Friedrich. Além do Bem e do Mal. São Paulo: Companhia das Letras, 2008a.

- Assim Falou Zaratustra. Rio de Janeiro: Civilização Brasileira, 2007.

. Aurora. São Paulo: Companhia das Letras, 2004.

. Ecce Homo - Como Alguém se Torna o que É.

São Paulo: Companhia das Letras, 2005b.

. A Filosofia na Era Trágica dos Gregos. São Paulo: Hedra, 2008.

. Genealogia da Moral. São Paulo: Companhia das Letras, 2009.

- Introdução à Tragédia de Sófocles. Rio de Janeiro: Jorge Zahar, 2006.

. O Nascimento da Tragédia ou Helenismo e Pessimismo. São Paulo: Companhia das Letras, 2005a.

Zahar, 2009a.

. Wagner em Bayreuth. Rio de Janeiro: Jorge

ORGANIZAÇÃO MUNDIAL DE SAÚDE. Classificação de Transtornos Mentais e de Comportamento da CID-10. Porto Alegre: Artes Médicas, 1993.

PAIM, Isaías. Curso de Psicopatologia. São Paulo: Ed. E.P.U., 1982. 
PEIRCE, Charles Sanders. Semiótica. São Paulo: Editora Perspectiva, 1995.

PELBART, Peter Pál. Vida Capital - Ensaios de Biopolítica. São Paulo: Iluminuras, 2003.

PENIDO, Cláudia M. F. A Clínica e a Formação nos CERSAMs de Belo Horizonte. In: Archivos de Saúde Mental e Atenção Psicossocial, Rio de Janeiro, n. 2, 2005.

PERRONE, Cláudia ; ENGELMAN, Selma. Cenas de um documentário: Ilhas Urbanas. In: RIZOMAS da Reforma Psiquiátrica - A Difícil Reconciliação. Porto Alegre: Sulina/ UFRGS, 2007.

PERRUSI, A. Imagens da Loucura - Representação social da doença mental na psiquiatria. Recife: Cortez Editora, Editora Universitária, 1995.

PESSOTTI, I. O Século dos Manicômios. São Paulo: Editora 34, 1996.

PINEL, Philippe. Tratado Medico-Filosofico de La Enagenacion Mental o Mania. Madrid: Ediciones Nieva, 1988[1800].

- Tratado Médico-Filosófico sobre a Alienação Mental ou a Mania. Porto Alegre: Editora da UFRGS, 2007[1800].

PINTO, Júlio. 1,2,3 da Semiótica. Belo Horizonte: Editora da UFMG, 1995.

PITTA, Ana Maria Fernandes. Cuidando de Psicóticos. In: Clínica da Psicose: Um Projeto na Rede Pública. Rio de Janeiro: Te Corá Editora, 1996.

PLATÃO. Banquete. São Paulo: Editora Martin Claret, 1999. . Teeteto. In: PORTAL Domínio Público. Disponível em: <www.dominiopublico.gov.br>. Acesso em: 14 set 2009. 
REALE, Giovanni; ANTISERI, Dário. História da Filosofia. Vol. 2. São Paulo: Paulus, 2007. v.2.

1990. v.1.

. História da Filosofia. São Paulo: Ed. Paulinas,

REVEL, Judith. Foucault - Conceitos Essenciais. São Carlos: Claraluz, 2005.

ROLNIK, Suely. Cartografia Sentimental - Transformações Contemporâneas do Desejo. Porto Alegre: Editora UFRGS Sulina, 2007.

ROTELLI, F. Superando o Manicômio: O Circuito Psiquiátrico de Trieste. In: AMARANTE, P. Psiquiatria Social e Reforma Psiquiátrica. Rio de Janeiro: Ed. Fiocruz, 1998.

ROUDINESCO, Elisabeth. Leituras da história da loucura (1961-1986). In.: ROUDINESCO et al. Foucault: leituras da história da loucura. Rio de Janeiro: Relume-Dumará, 1994.

SANTOS, Rone Eleandro dos. Genealogia da Governamentalidade em Michel Foucault. Dissertação de Mestrado. Belo Horizonte: Universidade Federal de Minas Gerais - UFMG, Faculdade de Filosofia e Ciências Humanas, 2010.

SARACENO, B. et al. Manual de Saúde Mental. São Paulo: HUCITEC, 2001.

SARAMAGO, José. Ensaio sobre a Cegueira. São Paulo: Companhia das Letras, 1999.

SAURÍ, J. J. El Naturalismo Psiquiátrico - História de las ideas psiquiátricas. Buenos Aires: Ediciones Lohlé - Lúmen, 1996.

SCHNEEWIND, J. B. A Invenção da Autonomia. São Leopoldo: Editora Unisinos, 2001.

SCHRAMM, Fermin Roland. A Autonomia Difícil. Revista Bioética, Brasília, v. 06, n.1, 1998. 
SCHREBER, Daniel Paul. Memórias de um Doente dos Nervos. Rio de Janeiro: Edições Graal, 1985[1903].

SEGRE, Marco et al.. O Contexto Histórico, Semântico e Filosófico do Princípio de Autonomia. Revista Bioética, Brasília, v.6, 1, 1998.

SENELLART, MICHEL. Situação dos Cursos. In: Segurança, Território, População. São Paulo: Martins Fontes, 2008.

SOALHEIRO, N. I. A Implantação do Projeto Assistencial de Saúde Mental no Distrito Sanitário do Barreiro. In: Dispositivos de Tratamento em Saúde Mental na Rede Pública: Construindo um Projeto. Belo Horizonte: Secretaria Municipal de Saúde, 1996.

SOUZA, Paulo César. Posfácio. In: A GAIA ciência. São Paulo: Companhia das Letras, 2009.

STAHL, Stephen M. Psicofarmacologia - bases Neurocientíficas e Aplicações Clínicas. Rio de Janeiro: MEDSI, 1998.

STENGERS, Isabelle. A Invenção das Ciências Modernas. São Paulo: Ed. 34, 2002.

. Quem tem medo da ciência? São Paulo: Siciliano,

1990.

SUASSUNA, Ariano. Iniciação à Estética. Rio de Janeiro: J.Olympio, 2007.

SZASZ, T. Cruel Compaixão. Campinas: Papirus Editora, 1994.

SZONDI, Peter. Ensaio sobre o Trágico. Rio de Janeiro: Jorge Zahar Ed., 2004.

TENORIO, F. A Reforma Psiquiátrica Brasileira, da Década de 1980 aos Dias Atuais: História e Conceitos. História Ciência Saúde - Manguinhos, Rio de Janeiro, v. 9, n. 1, jan./abr. 2002. 
TESTA, Mário. Saber em Salud - la construcción del conocimiento. Buenos Aires: Lugar Editorial, 1997.

TURATO, Egberto Ribeiro. Tratado da Metodologia da Pesquisa Clínico-Qualitativa. Petrópolis: Editora Vozes, 2003.

WORLD HEALTH ORGANIZATION. Treatment of Mental Disorders: a Review of Effectiveness. Washington: WHO, 1993.

YASUY, Sílvio. CAPS: Aprendendo a Perguntar. In: Saúdeloucura. São Paulo: HUCITEC, 1989. n.1. 


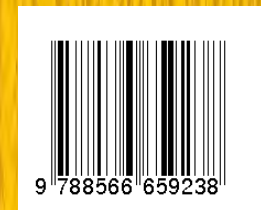

\section{Publicações da Editora Rede UNIDA}

\section{Coleções e Série}

Arte Popular, Cultura e Poesia

Clássicos da Saúde Coletiva

Micropolítica do Trabalho e o Cuidado em Saúde

Cadernos da Saúde Coletiva

\section{Outras publicações}

"Bulindo" com a Universidade - Um estudo sobre o trote na medicina

Girando Vida, Políticas e Existências: reunindo experiências com leveza e movimento - Construção do 11ำ Congresso Internacional da Rede UNIDA

Evidencias y Narrativas - Una perspectiva antropológica.

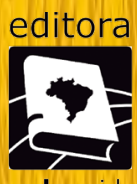

redeunida

www.redeunida.org.br 